\title{
29. FACIES EVOLUTION, CARBONATE DISSOLUTION CYCLES IN SEDIMENTS FROM THE EASTERN SOUTH ATLANTIC (DSDP LEG 40) SINCE THE EARLY CRETACEOUS ${ }^{1}$
}

\author{
Marthe Melguen, Centre Océanologique de Bretagne, B.P. 337, 29273 Brest, France
}

\begin{abstract}
Facies evolution in continental margin sediments recovered on Leg 40 from the eastern South Atlantic reflects a progressive disappearance of stagnant conditions and a decrease of the terrigenous influx at the end of the Cretaceous. The Maestrichtian-Paleocene is characterized by the definitive installation of well-oxygenated oceanic conditions. The first upwelling phenomena off Southwest Africa occurred during the Eocene. Carbonate dissolution cycles have recurred several times since the Early Cretaceous. A tentative mean CCD curve for the South Atlantic since the Late Cretaceous is presented. Carbonate dissolution is considerably enhanced in upwelling areas, such as the easternmost Walvis Ridge and the Angola Margin, and is not comparable with that observed in adjacent oceanic basins, such as the Cape Basin. The carbonate dissolution cycles are reflected in the carbonate content of the sediments, in the degree of fragmentation of planktonic foraminifers, and in the relative abundance of benthic foraminifers and fish debris. This evidence is in general agreement with that deduced from the degree of dissolution of calcareous nannofossils (Noël and Melguen, this volume).
\end{abstract}

\section{INTRODUCTION}

\section{General}

The present study is focused on the eastern side of the South Atlantic Ocean, i.e., the Cape and Angola basins, their adjacent continental margins, and the Walvis Ridge (DSDP Leg 40). Emphasis is on the evolution of Cretaceous and Cenozoic facies in these basins and on the ridge and on the role played by the Walvis Ridge as a barrier between the basins. Attention is also given to Cretaceous and Cenozoic carbonate dissolution cycles, and to the major factors controlling this dissolution. These factors depend not only on regional environmental conditions, but also on worldwide oceanic changes, such as variations in the oceanic spreading rate, expansion of Antarctic glaciation, fluctuations of Antarctic bottom-water circulation, development of surface current circulation, climatic changes, transgression-regression cycles, and tectonic events. Most of these factors are extremely complex and poorly understood.

Using the facies distribution of all DSDP sites drilled on Legs $3,36,39$, and 40 in the South Atlantic, a mean paleo-CCD curve is proposed.

The location of Leg 40 drill sites is shown on Figures 1, 2 , and 3 . The position, water depth, and thickness of sediments drilled at each site are given in Table 1.

\section{Analytical Methods and Methodology}

Lithologic changes noted from visual examination of the cores were studied by means of smear slides aboard ship and further smear slides made on shore. The lithologic classifi-

\footnotetext{
${ }^{1}$ Contribution 529 of the Départment Scientifique, Centre Océanologique de Bretagne.
}

cation used in this report is the general classification used by the Deep-Sea Drilling Project (cf. Chapter 1 Appendix, this volume). Several hundred samples were taken on board ship, and the calcium carbonate content was determined ashore for each sample using a Bernard calcimeter. For each sample the coarse fraction (63-2000 $\mu \mathrm{m})$ was sieved, dried, and weighed. Finally the coarse fraction itself was sieved using a $250 \mu \mathrm{m}$ standard sieve in order to estimate the relative abundance of the (63-250 $\mu \mathrm{m})$ fraction compared with the entire coarse fraction (cf. Appendix A). The composition of the total coarse fraction was studied under the microscope, and proportions of the different components were visually estimated. Comparisons were made between coarse fraction observations made on board Glomar Challenger and observations made later in the laboratory. The comparison proved the reproducibility of the method used.

The major coarse fraction components of Leg 40 sediments can be grouped as follows:

\begin{tabular}{|c|c|c|c|c|c|}
\hline \multicolumn{4}{|c|}{ Biogenous Components } & \multirow{3}{*}{$\begin{array}{r}\text { Terrigenous } \\
\text { Components }\end{array}$} & \multirow{3}{*}{$\begin{array}{r}\text { Authigenic } \\
\text { Components }\end{array}$} \\
\hline \multicolumn{2}{|c|}{ Calcareous } & \multirow{2}{*}{ Siliceous } & \multirow{2}{*}{$\begin{array}{c}\text { Phosphate } \\
\text { \& } \\
\text { Others }\end{array}$} & & \\
\hline Planktonic & Benthic & & & & \\
\hline \multirow[t]{5}{*}{$\begin{array}{l}\text { Foramini- } \\
\text { fers }\end{array}$} & $\begin{array}{l}\text { Foramini- } \\
\text { fers }\end{array}$ & $\begin{array}{l}\text { Radiola- } \\
\text { rians }\end{array}$ & $\begin{array}{l}\text { Fish } \\
\text { debris }\end{array}$ & $\begin{array}{l}\text { Plant } \\
\text { debris }\end{array}$ & $\begin{array}{l}\text { Pyrite } \\
\text { Glauconite }\end{array}$ \\
\hline & Ostracodes & Diatoms & Arenaceous & Quartz & Barite \\
\hline & Echinoids & Sponge- & forami- & Mica & \\
\hline & $\begin{array}{l}\text { Lamelli- } \\
\text { branchs }\end{array}$ & spicules & nifers & $\begin{array}{l}\text { Other } \\
\text { Minerals }\end{array}$ & \\
\hline & Bryozoans & & & & \\
\hline
\end{tabular}

The distribution of these coarse-fraction components is given in Appendix B, and is plotted in Figures 1, 2, and 3.

Special attention was given to the preservation of calcareous biogenous components and especially to that of 


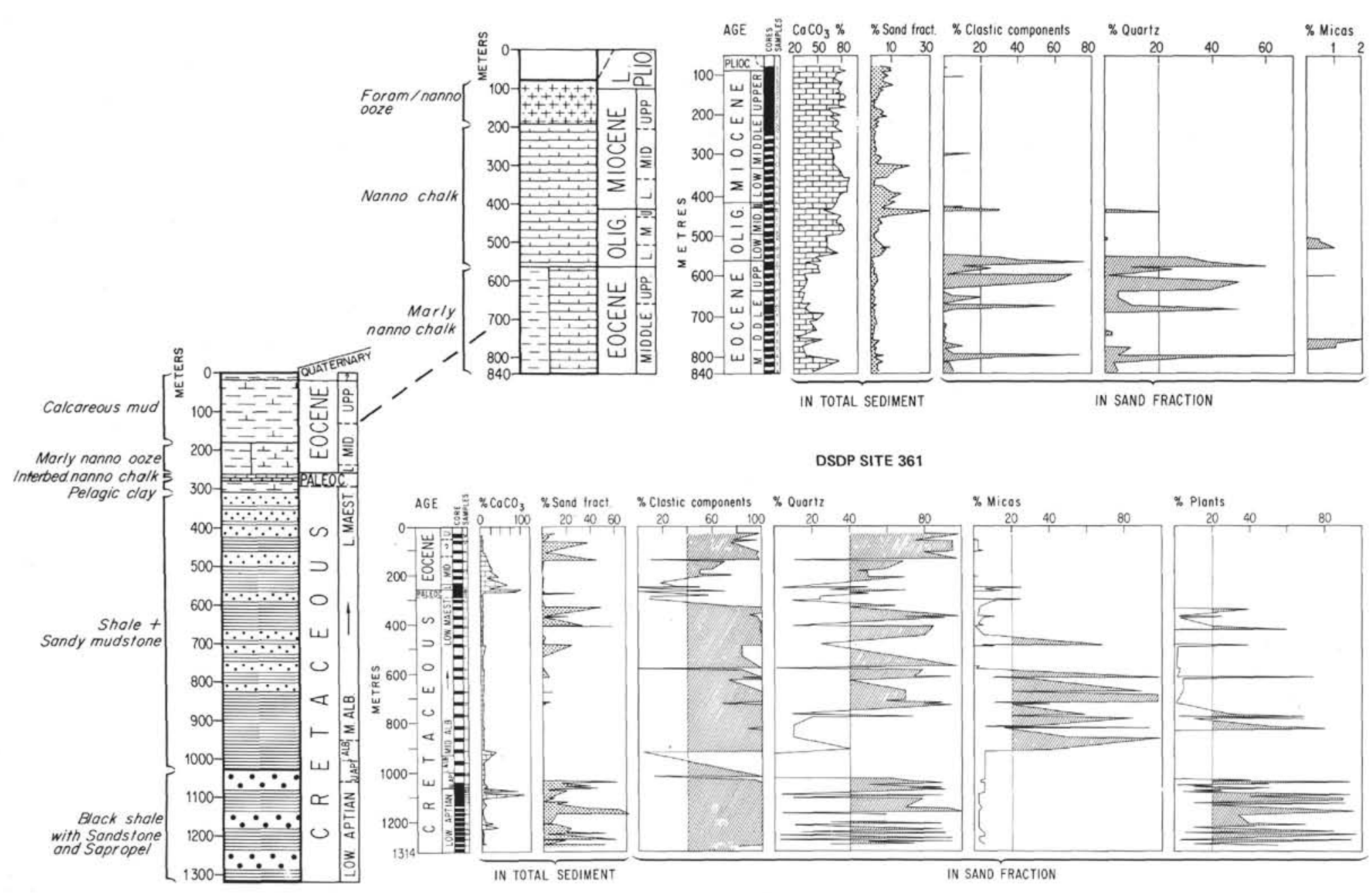

Figure 1. Facies evolution at Sites 360 and 361, Cape Basin continental margin, as shown on lithologic columns. Base of correlative Units 4 and $4 a$ at Sites 360 and 361, respectively, are connected by a dashed line. Graph shows variations in carbonate content and sand fraction content with respect to total sediment and variations in most significant biogenous and terrigenous components in the sand fraction (63-2000 $\mu \mathrm{m})$ with depth. Also shown is degree of fragmentation of planktonic foraminifers in the total sand fraction with depth. 

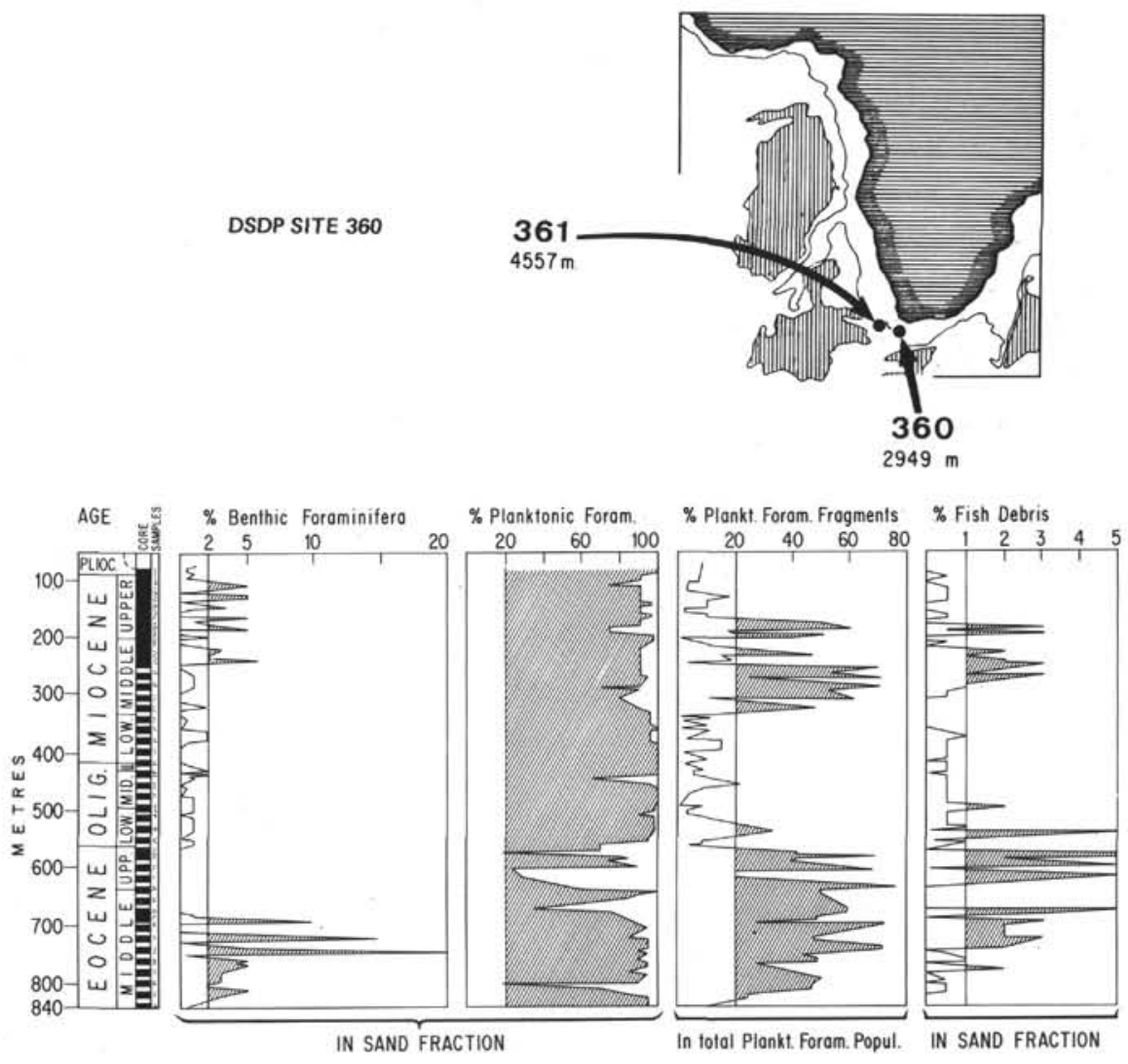

DSDP SITE 361

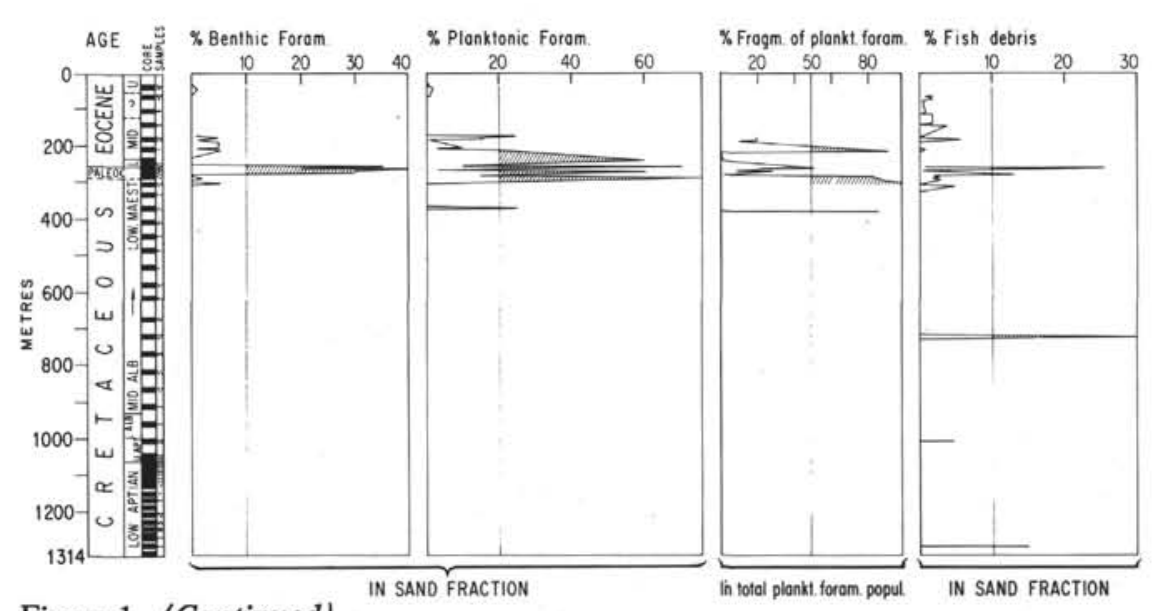

Figure 1. (Continued). 


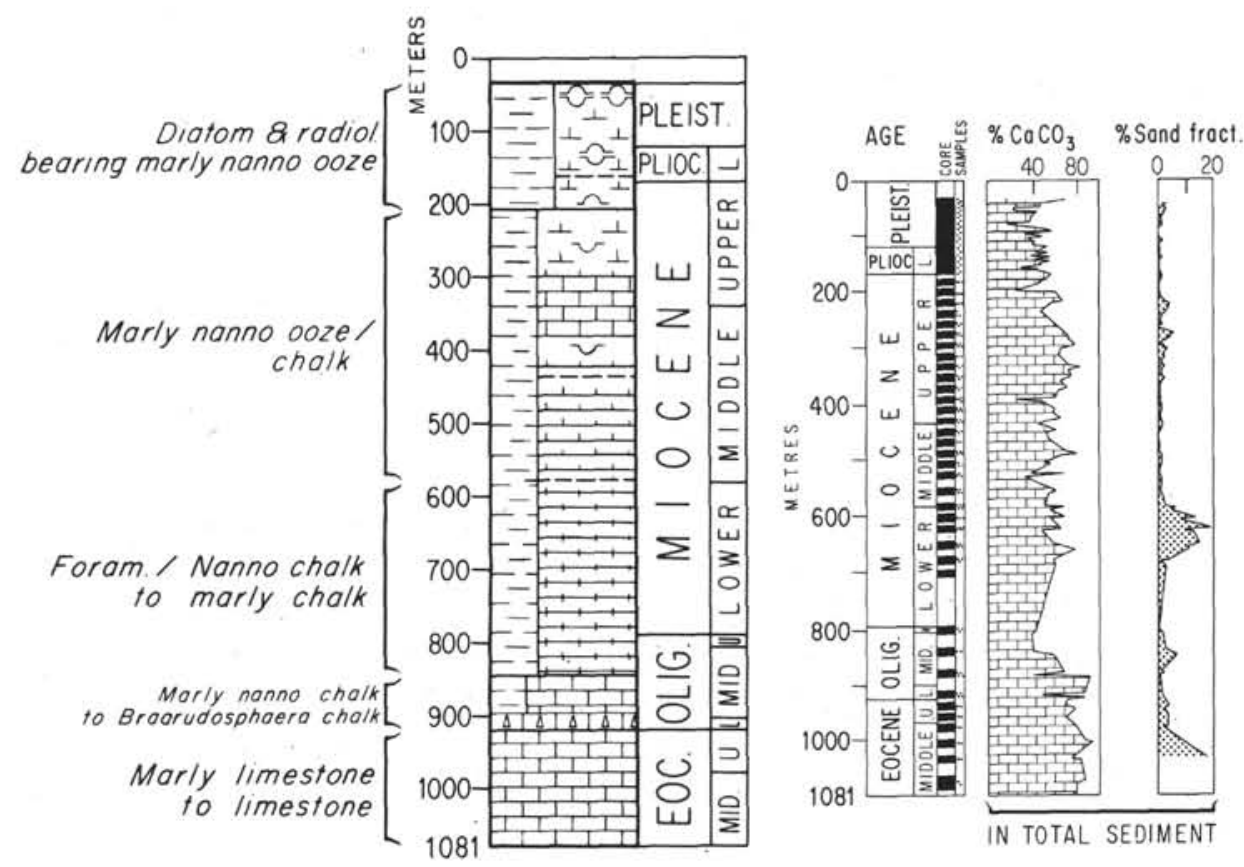

DSDP 363

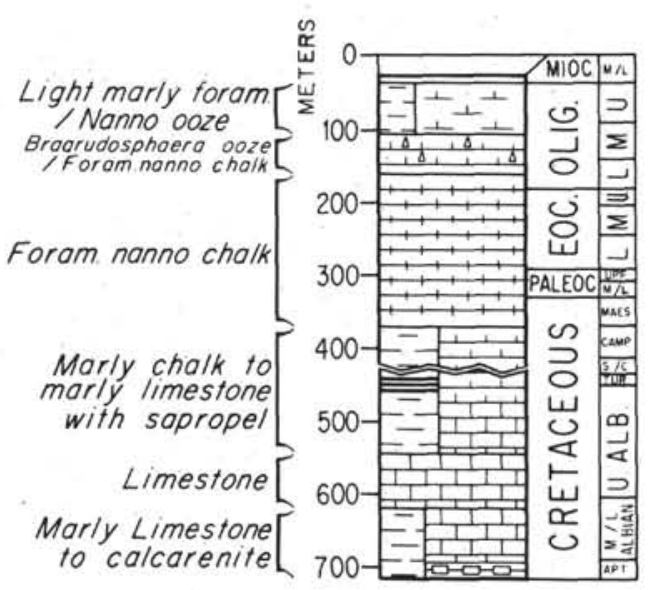

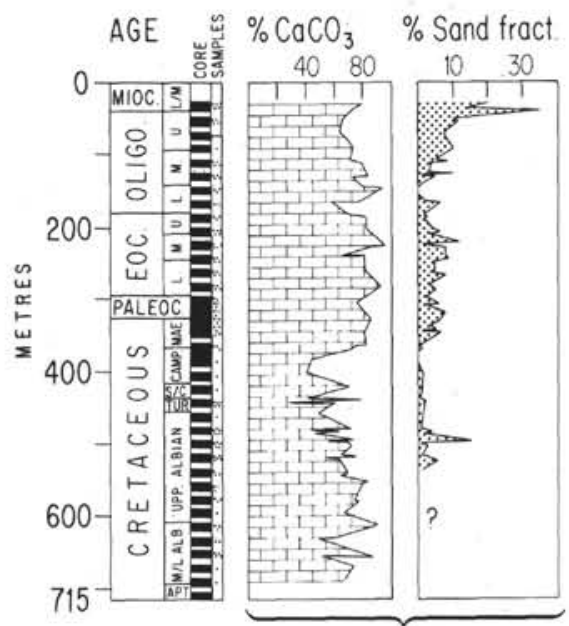

IN TOTAL SEDIMENT

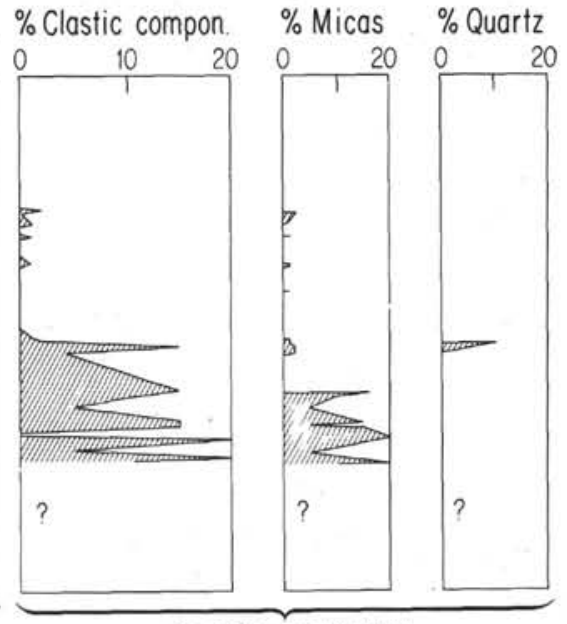

IN SAND FRACTION

Figure 2. Facies evolution at Sites 362 and 363, Walvis Ridge, as shown on lithologic columns. Graphs show variations in carbonate content and sand fraction content with respect to total sediment and variations in most significant biogenous and terrigenous components in the sand fraction (63-2000 $\mu \mathrm{m})$ with depth. Also shown is degree of fragmentation of planktonic foraminifers in the total sand fraction with depth.

planktonic foraminifers. The degree of fragmentation of planktonic foraminifers observed in the coarse fraction is considered to reflect the degree of carbonate dissolution. In general, the dissolution of calcareous nannofossils increases with increasing water depth (Berger, 1973; Melguen and Thiede, 1974). With increasing carbonate dissolution the abundance of planktonic foraminifers decreases while the abundance of benthic calcareous foraminifers, which on the whole are more resistant to dissolution, increases. Therefore deep-sea sediments show an increasing benthic- to planktonic-foraminiferal ratio with progressive dissolution, and calcareous benthic foraminifers persist at oceanic depths greater than the depth at which all planktonic foraminifers have been destroyed (Melguen and Thiede, 1974; Adelseck, 1977). Dissolution of calcareous fossils leads to a relative enrichment of fish debris in the sediments.

Therefore the carbonate dissolution cycles proposed in this paper are based primarily on the total calcium carbonate content, the general composition of the coarse fraction, the relative abundance of benthic foraminifers and fish debris, and the relative abundance and degree of fragmentation of planktonic foraminifers. The relative abundance of planktonic foraminifer fragments with respect to whole tests 


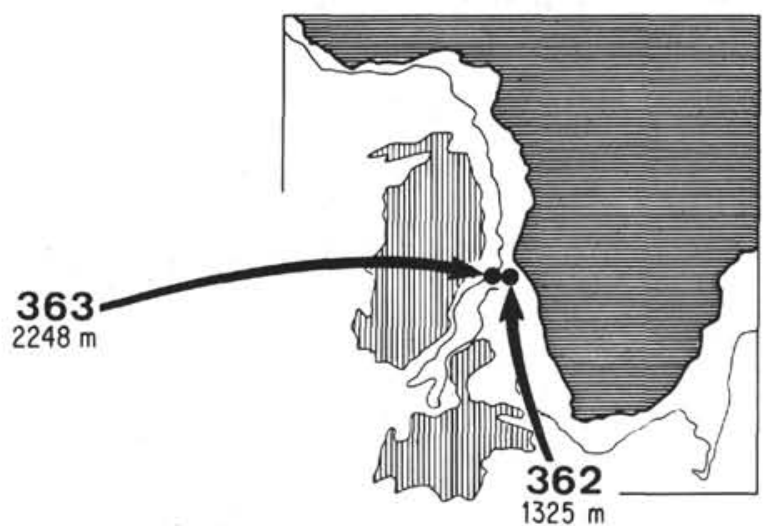

DSDP 362
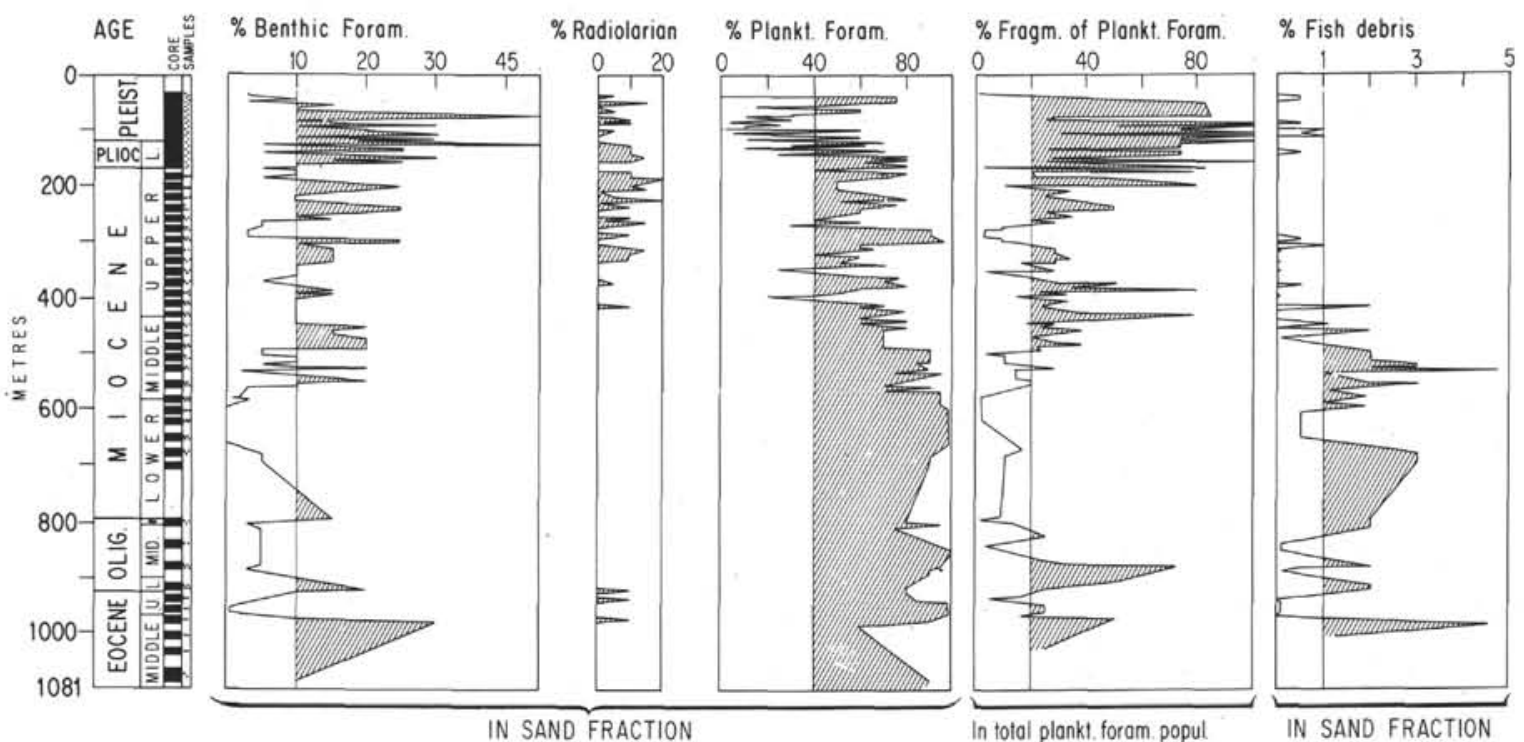

DSDP 363
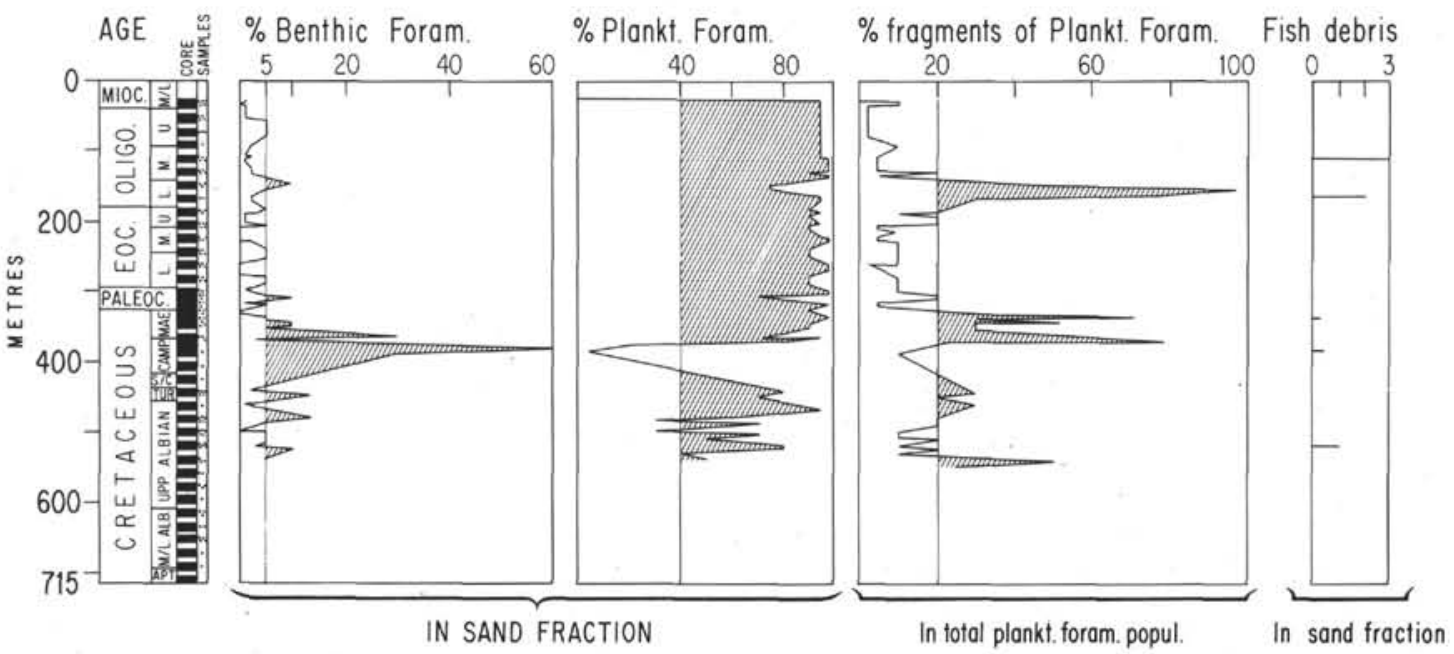

Figure 2. (Continued).

has been visually estimated. Estimations were done on a plane surface using the chart of Terry and Chillinger (1955). A double estimation, at several hours interval, was done on every tenth sample for testing the reliability of the estima- tion. Differentiation between whole tests and fragments of planktonic foraminifers was done by considering each test greater than $\sim 75 \%$ whole as a whole test and all the rest as fragments. In addition, a complementary scanning electron 


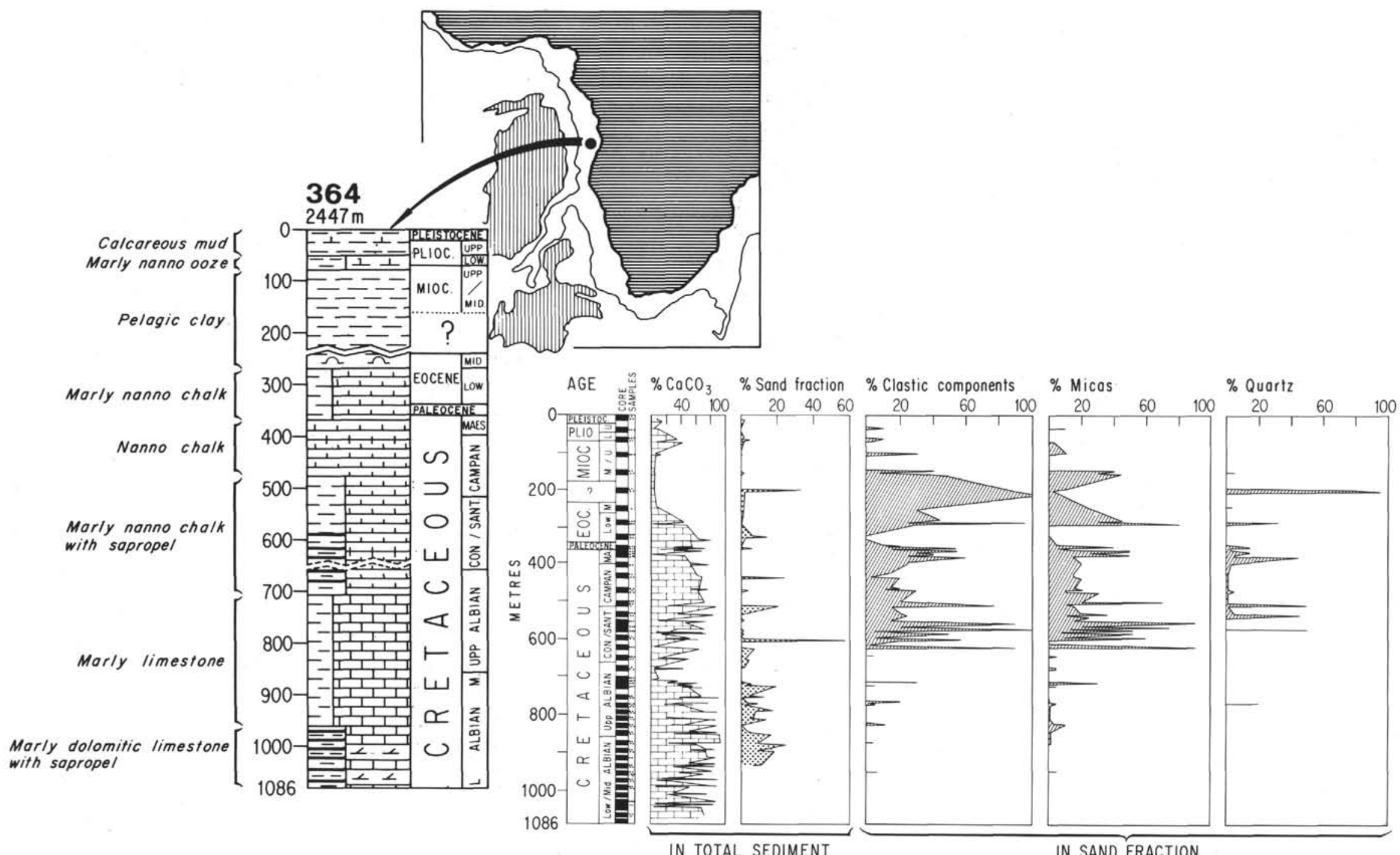

IN TOTAL SEDIMENT

IN SAND FRACTION

Figure 3. Facies evolution at Site 364, Angola Basin, as shown on lithologic columns. Graphs show variations in carbonate content and sand fraction content with respect to total sediment and variations in most significant biogenous and terrigenous components in the sand fraction (63-2000 $\mu \mathrm{m})$ with depth. Also shown in degree of fragmentation of planktonic foraminifers in the total sand fraction with depth. 


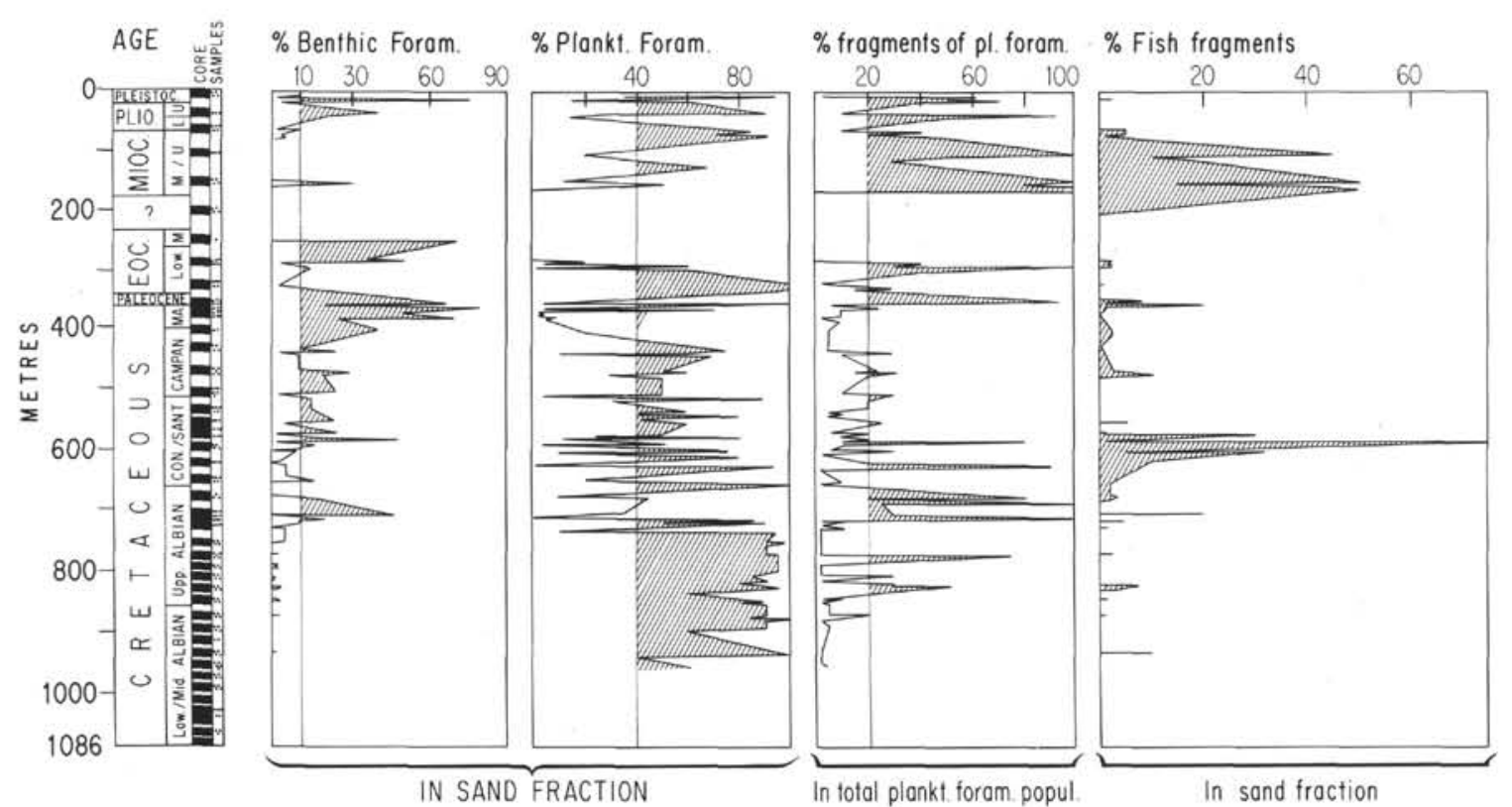

Figure 3. (Continued): 
TABLE 1

Leg 40 Coring Summary (all depths in meters)

\begin{tabular}{|c|c|c|c|c|c|c|c|c|c|}
\hline Hole & Dates & Latitude & Longitude & $\begin{array}{l}\text { Water } \\
\text { Depth }^{\mathrm{a}}\end{array}$ & Penetration & $\begin{array}{l}\text { No. of } \\
\text { Cores }\end{array}$ & $\begin{array}{l}\text { Meters } \\
\text { Cores }\end{array}$ & $\begin{array}{c}\text { Meters } \\
\text { Recovered }\end{array}$ & $\begin{array}{l}\text { Percent of } \\
\text { Recovery } \\
\text { (\%) }\end{array}$ \\
\hline 360 & $\begin{array}{c}\text { 20-27 Dec. } \\
1974\end{array}$ & $35^{\circ} 50.75^{\prime} \mathrm{S}$ & $18^{\circ} 05.79^{\prime} \mathrm{E}$ & 2949 & 839.5 & 50 & 475.0 & 278.1 & 58.6 \\
\hline 361 & $\begin{array}{c}\text { 5-13 Jan. } \\
1975\end{array}$ & $35^{\circ} 03.97^{\prime} \mathrm{S}$ & $15^{\circ} 26.91^{\prime} \mathrm{E}$ & 4549 & 1314.0 & 49 & 465.5 & 222.07 & 47.7 \\
\hline 362 & $\begin{array}{c}\text { 17-21 Jan. } \\
1975\end{array}$ & $19^{\circ} 45.45^{\prime} \mathrm{S}$ & $10^{\circ} 31.95^{\prime} \mathrm{E}$ & 1325 & 805.5 & 44 & 418.0 & 367.25 & 87.8 \\
\hline $362 \mathrm{~A}$ & $\begin{array}{c}\text { 21-23 Jan. } \\
1975\end{array}$ & $19^{\circ} 45.45^{\prime} \mathrm{S}$ & $10^{\circ} 31.95^{\prime} \mathrm{E}$ & 1325 & 1081.0 & 12 & 109.5 & 76.95 & 70.4 \\
\hline 363 & $\begin{array}{c}\text { 24-28 Jan. } \\
1975\end{array}$ & $19^{\circ} 38.75^{\prime} \mathrm{S}$ & $09^{\circ} 02.80^{\prime} \mathrm{E}$ & 2248 & 715.0 & 40 & 380.0 & 226.9 & 59.7 \\
\hline 364 & $\begin{array}{c}30 \text { Jan.-Feb. } \\
1975\end{array}$ & $11^{\circ} 34.32^{\prime} \mathrm{S}$ & $11^{\circ} 58.30^{\prime} \mathrm{E}$ & 2448 & 1086.0 & 46 & 427.5 & 295.6 & 69.1 \\
\hline 365 & $\begin{array}{c}\text { 6-8 Feb. } \\
1975\end{array}$ & $11^{\circ} 39.10^{\prime} \mathrm{S}$ & $11^{\circ} 53.72^{\prime} \mathrm{E}$ & 3018 & 687.0 & 7 & 63.0 & 34.65 & 55.0 \\
\hline Totals & & & & & 6528.0 & 248 & 2338.5 & 1501.52 & 64.21 \\
\hline
\end{tabular}

${ }^{\text {a }}$ PDR depths.

microscope study of the nannofossil preservation was done (Noël and Melguen, this volume) to confirm or contradict inferences drawn from the coarse fraction analysis. Dissolution of calcareous nannofossils is reflected both in the abundance and in the etching patterns of nannofossils.

Berger and Roth (1975) state that calcareous nannofossils are as solution resistant as foraminifers. Other researchers, observing that nannofossils persist at relatively greater depths than foraminifers, suggest that calcareous nannofossils are more resistant to dissolution than foraminifers (Schneidermann, 1973). Recent experiments of Adelseck (1977) point out that tropical nannofossil assemblages may be less resistant to dissolution than the assemblage of larger planktonic foraminifers. The degree of dissolution increases not only with depth of deposition (Schneidermann, 1973; Berger, 1973), but also as a function of the content of organic matter in the sediments (Berger and Winterer, 1974). Thus, dissolution increases drastically in areas of high fertility, such as areas of upwelling.

The degree of dissolution with depth is characterized by two different levels - the CCD and the lysocline. The lysocline has been defined by Berger (1970) as the level at which the degree of preservation of the calcareous microfossils shows a rapid decline. Throughout this paper, the lysocline referred to will be the planktonic foraminifer lysocline. I have estimated this level by defining a boundary between well-preserved and poorly preserved foraminifer assemblages. I take this boundary to be at the level where fragmentation of the tests increases from less than $20 \%$ to more than $50 \%$. The boundary in fact is a zone, or range of depths, but is narrow enough to be considered effectively as a specific depth. This level is considered equivalent to the "foraminiferal-lysocline:" In the Rio Grande Rise area it is 500 meters higher than the CCD (Melguen and Thiede, 1974). Elsewhere this depth difference can vary by several hundred meters (Berger et al., 1976; Biscaye et al., 1976; Venkatarathnam et al., 1976). However, refinements of the depth difference between "lysocline" and "CCD" are not contemplated here, considering estimated uncertainties of paleodepth reconstruction of 200-300 meters at each DSDP site. Therefore, a depth difference of 500 meters between the "lysocline" and the "CCD" is taken as the average for the reconstruction of the CCD in the South Atlantic in the past.

The concept of the CCD (Bramlette, 1961) is rather clearly defined as the level where rates of carbonate supply and carbonate dissolution balance. Operationally it is often difficult to find the exact depth level where this occurs (Berger and Winterer, 1974). These operational difficulties are very obvious in the different methods used to fix the CCD level in recent publications (Berger et al., 1976; Biscaye et al., 1976; Venkatarathnam et al., 1976). The CCD as here understood is the boundary between calcareous and carbonate-free pelagic sediments. In practice the boundary was put where carbonate content dropped below $5 \%$. At various geological times the drilled sites were situated well above the CCD. In these cases I have estimated the CCD level by reference either to the lysocline level (when it has been reached) or the presence of better preserved calcareous deposits.

Particular attention is given to three facies types, which may reflect the depth of the CCD in the past: pelagic clay deposited at or below the CCD; marls deposited at the lysocline level ( $\%$ of fragmentation of planktonic foraminifers $>50 \%$; cf. Melguen and Thiede, 1974); and well-preserved calcareous ooze or chalk ( $\%$ of fragmentation $<20 \%$ ). It is assumed that the sedimentary sequences with respect to the CCD were similar in the past to those presently off Brazil (Melguen and Thiede, 1974).

Sites drilled in high productivity zones (e.g., 362-362A and 364) are not comparable with sites drilled in adjacent basins and cannot help in determining an average CCD level. The lysocline is much more elevated in high productivity zones and is therefore not directly comparable to the lysocline in the central ocean basins (Bramlette, 1965; Tappan, 1968; Broecker, 1971; Berger and Roth, 1975).

In every case the reconstruction of an average $\mathrm{CCD}$ for a whole ocean through time can only be very tentative and 
uncertain given the various factors which could have influenced the CCD fluctuations in the past (oceanic fertility, oceanic circulation, carbonate supply from continents, distance from continents, succession of transgressions and regressions, climatic cycles-Berger, 1970; Seibold, 1970; Berger and Winterer, 1974).

\section{Time Scales}

Biostratigraphic ages for sediments described in this paper are taken from Chapters 2-4 (this volume). The Cretaceous and Cenozoic time scales used in the discussion of the kinematic evolution of the South Atlantic are those proposed by Thierstein (1976) and Tarling and Mitchell (1976), respectively.

\section{Presentation of Data}

The data in Appendices A and B are presented in graphical form on Figures 1, 2, and 3. In the following sections, the relative depth of the CCD and the lysocline are inferred from the levels of pelagic clay, marls, and well-preserved calcareous oozes and chalks, using the assumptions outlined above, especially the degree of fragmentation of planktonic foraminifers in the marls. Additional factors such as the role of diagenesis are discussed site by site. After summarizing the data for each site, the bearing of the data on sediment accumulation rates, bathymetric evolution, and the CCD will be presented.

\section{SEDIMENTARY FACIES EVOLUTION ALONG THE EASTERN SIDE OF THE SOUTH ATLANTIC}

\section{Cape Basin, Sites 360 and 361, Lithologic Units}

Sites 360 and 361 together penetrated almost the entire sedimentary section of the continental margin off the southern tip of Africa. At Site 360 the drilling penetrated Tertiary sediments, and at Site 361 Eocene to Early Cretaceous sediments at a place nearby where most of the Tertiary section had been removed. Sedimentary units of the two sites are numbered consecutively, overlapping in the Eocene, Unit 4. They are described from the oldest, Unit 7 Site 361 , to the youngest, Unit 1, Site 360 .

\section{Unit 7, Site 361}

Black shale with sandstone and sapropel, lower Aptian to upper Aptian, 1314-1010 meters (Cores 49-28).

This unit consists of alternating black shale and gray to dark gray sandy mudstone and sandstone (Figure 1). Black shales are very fine (clay and silt $>90 \%$ ) and homogeneous, with only rare and scattered fine white calcareous laminae. They have low $(<4 \%)$ calcium carbonate. In the white laminae, however, the calcium carbonate content may reach $85 \%$ and more (Appendix A, Figure 1). The black shales are rich in pyrite $(<10 \%)$ reflecting reducing conditions in the environment. Sandstone and sandy mudstone layers are massive and variable in thickness $(10-100 \mathrm{~cm})$. They are unsorted or poorly sorted. They have only rare laminations. Their coarse fraction (63-2000 $\mu \mathrm{m})$ content is highly variable $(10-75 \%)$ and consists of quartz (1-90\%), plant debris $(2-90 \%)$, and mica $(<10 \%)$, with less feldspar and biotite. The association of coarse angular quartz with plant debris (Figure 1) suggests very rapid deposition, without winnow- ing. The great quantity of angular quartz grains associated with feldspars, and the absence of sedimentary structures or even traces of bioturbation further support this interpretation. They could correspond to proximal turbidite or to deep-sea fan deposits at the base of a submarine canyon (Chapter 2, this volume).

Dilution by terrigenous material and in situ calcium carbonate dissolution are responsible for the very low carbonate content of this sedimentary sequence. The latter is supported by the presence of molds of coccoliths in the bituminous black shales (e.g., Core 48) (Noël and Melguen, this volume), and by the relative abundance of fish debris (e.g., 15\% in Core 48, Figure 1) in the sand fraction.

\section{Unit 6, Site 361}

Greenish black to dark gray shale with sandy mudstone, upper Aptian to Maestrichtian, 963.5-326 meters (Cores 27-13).

This unit consists of dark gray to greenish black shales alternating with reddish shalesand having intercalations of greenish gray sandy mudstones and of sandstone beds (Figure 1). Compared with Unit 7 , the sediments are much finer grained, the sand fraction is less abundant (Appendix A, Figure 1), and sandstone beds are restricted to the upper part of the unit (Cores 15 to 13, Figure 1). The abundance in mudstones of parallel and cross-bedded fine-grained sandy and silty laminae (e.g., Cores 25 to $20 ; 867$ to $610 \mathrm{~m}$ ) together with the presence of erosional features, suggests that this sedimentary sequence might correspond to the distal portions of turbidites or might have been sculpted by bottom currents. They might also correspond to deep-sea fan deposits. With respect to Unit 7 , the decrease of the sand fraction (and therefore of the coarse terrigenous input), the relative abundance of mica compared to quartz, and the decrease of plant debris suggest a greater distance from the site to the source, and a probable decrease of the rainfall on the continent, from upper Aptian to Maestrichtian. At the end of this time however, coarser quartzous layers were deposited again, and may have corresponded to a shift in the channels of deep-sea fans, as is often seen in modern deltaic environments. The reddish shales indicate that oxygenated, rather than anoxic, bottom conditions prevailed at this time.

As in Unit 7, the calcium carbonate content of Unit 6 sediments is very low ( $<4 \%$; cf. Appendix A). Coccoliths are very rare, and more often represented in the sediment by molds (e.g., Core 28; cf. Noël and Melguen, this volume). The complete absence of calcareous foraminifers in the sediments (Figure 1) and the presence of only impressions of coccoliths suggest deposition of the upper Aptian/ Maestrichtian sediments at or below the CCD, as was probably also the case for Unit 7 .

\section{Unit 5, Site 361}

Pelagic Clay, Paleocene, 307-263.5 meters (Cores 12-9).

This unit marks a significant change in the pattern of sedimentation. The black shales and sandy mudstones of Unit 6 are replaced by brown pelagic clay (Figure 2). These are very fine (clay size particles $\approx 80 \%$; sand fraction $<1 \%$ ) and homogeneous. No sedimentary structures and no traces of bioturbation are visible.

The calcium carbonate content is very low $(<5 \%)$, except at the upper part of the unit where a chalk layer (e.g., Core 
10) contains up to $100 \% \mathrm{CaCO}_{3}$. This layer, however, which contains a high percentage $30-40 \%$ of the coarse fraction) of benthic foraminifers associated with a few (5$10 \%$ ) planktonic foraminifers (Figure 1) is very probably not in place but transported there from shallower depths (see Chapter 2, this volume).

The pelagic clay consists essentially' of clay minerals (among which are zeolites) associated with quartz; a few benthic foraminifers and planktonic foraminifer fragments, fish debris (Appendix B, Figure 1), glauconite, barite, and pyrite occur also in the sand fraction (e.g., Core 10; Appendix B). These sediments are typical of sediments deposited at or below the CCD.

\section{Unit 4A, Site 361}

Marly nannofossil ooze to calcareous mud and mud, upper Paleocene to upper Eocene, 263.5-31.5 meters (Cores 9-1).

This unit begins with a marly nannofossil ooze and ends with calcareous mud (Figure 1). No sedimentary structures and no traces of bioturbation are visible.

The calcium carbonate content drops progressively from $82 \%$ in Core $8(\approx 255 \mathrm{~m}$ ) to $4 \%$ or less in Core 1 (Appendix A, Figure 1). From the lower to middle Eocene there is a net decrease in the abundance of benthic and planktonic foraminifers, associated with an increase in the degree of fragmentation of planktonic foraminifers and in the abundance of fish debris. This evolution reflects a deepening of the site, or a progressive rise of the CCD at that time. The nannofacies analysis (Noël and Melguen, this volume) confirms the presence of clear traces of dissolution on the nannofossils as early as the early Eocene (Core 6). The decrease in the calcium carbonate content is partly the result of dilution by non-calcareous terrigenous material, such as quartzose sand (Figure 1). From the end of the middle Eocene this terrigenous material strongly diluted the biogenous components (benthic and planktonic foraminifers, fish debris) when these existed (Figure 1).

\section{Unit 4, Site 360}

Marly nannofossil chalk, middle to upper Eocene, 840568 meters (Cores 50-36).

This unit consists of greenish gray marly nannofossil chalk. It correlates with, and is similar to, Unit 4 of Site 361 . It consists mainly of calcareous nannofossils (30-60\%) and of clay minerals $(25-65 \%)$. These components are associated with quartz $(3-5 \%)$ and pyrite $(<1 \%)$.

The coarse fraction study (Figure 1) shows that the relatively low carbonate content of the Eocene marls is due to both dilution and dissolution. The input of terrigenous material is reflected by the relative abundance of quartz and micas in the coarse fraction (Figure 1, Appendix B). Carbonate dissolution is obviously reflected in the degree of fragmentation of the planktonic foraminifers and the relative abundance of benthic foraminifers and of fish debris. Carbonate dissolution is, at least in part, responsible for the presence of middle/upper Eocene marls at Site 360. Furthermore the degree of fragmentation (50-70\%; Figure 1) of planktonic foraminifers indicates that these marls have been deposited at or near the lysocline level, that is approximately 500 meters above the $\mathrm{CCD}$, as previously discussed. One may note, however, that although the degree of fragmentation of planktonic foraminifers is generally greater than or equal to
$50 \%$, it is much lower in a few samples, where better preserved planktonic foraminifers are associated with a smaller amount of benthic foraminifers and of fish debris (Figure 1). This reflects the presence of cycles in the carbonate preservation. Furthermore, the nannofacies studied in three marly chalk samples from these intervals show well-preserved nannofossils (Noël and Melguen, this volume). These nannofossils, however, could have been redeposited from shallower depths, or transported through the water column inside fecal pellets (Honjo, 1975) and preserved from dissolution.

\section{Units 3 and 2}

Nannofossil chalk, lower Oligocene to upper Miocene, 568-181 meters (Cores 35-12).

These units consist of yellow-gray to light bluish gray nannofossil chalk with intercalations of foraminiferal nannofossil chalk and of greenish gray marl nannofossil chalk. Compared with the Unit 4 , they are characterized by higher calcium carbonate (from $30-50 \%$ to $70-90 \%$ ) and high sand fraction content (Figure 1). This increase is due to a decrease in the calcium carbonate dissolution and to a decrease of the terrigenous input (Figure 1).

On the contrary, a net increase in calcium carbonate dissolution characterizes the middle Miocene. As in the middle/upper Eocene the sediments were deposited at or near the lysocline level (cf. Figure 1; degree of fragmentation of planktonic foraminifers $>50 \%$ ). I attribute this increase in calcium carbonate dissolution, as reflected in the poor preservation of the calcareous nannofossils (Noël and Melguen, this volume), to a rise in the CCD in the Cape Basin.

\section{Unit 1}

Nannofossil ooze, upper Miocene to lower Pliocene, 18179.5 meters (Cores 11-1).

Unit 1 consists of light bluish gray to very light gray nannofossil ooze and foraminiferal nannofossil ooze. It is not very different from Units 2 and 3 except that it is less indurated. The carbonate content is still close to $80 \%$ (Figure 1). The increase of the sand fraction (mainly carbonate sand) from the middle/upper Miocene to the Pliocene correlates with a decrease of planktonic foraminifers, from $60 \%$ at the middle/upper Miocene boundary to less than $10 \%$ at the top of the Miocene. Observations on calcareous nannofossils (Noël and Melguen, this volume) concerning carbonate dissolution are in general agreement with those on planktonic foraminifers.

As in Units 2 and 3 the terrigenous component seems astonishingly low ( $<20 \%$; Appendix B) and fine for a continental rise. The sand fraction contains almost no clastic components (Figure 1).

\section{Sediment Accumulation Rates}

The high rate of accumulation $(60 \mathrm{~m} / \mathrm{m} . y$. , Figure 4$)$ of Aptian and Albian sediments in the Cape Basin (Site 361) is the result of the massive contributions of terrigenous sands. This supply was not continuous but intermittent, as shown by the interbedding of fine-grained shale and sandy beds. The association of plant fragments with poorly sorted coarse sand suggests mass transport, with a short distance of transport from sourcelands. We may be dealing here, for example, with mudflows pouring along canyons from the continental 


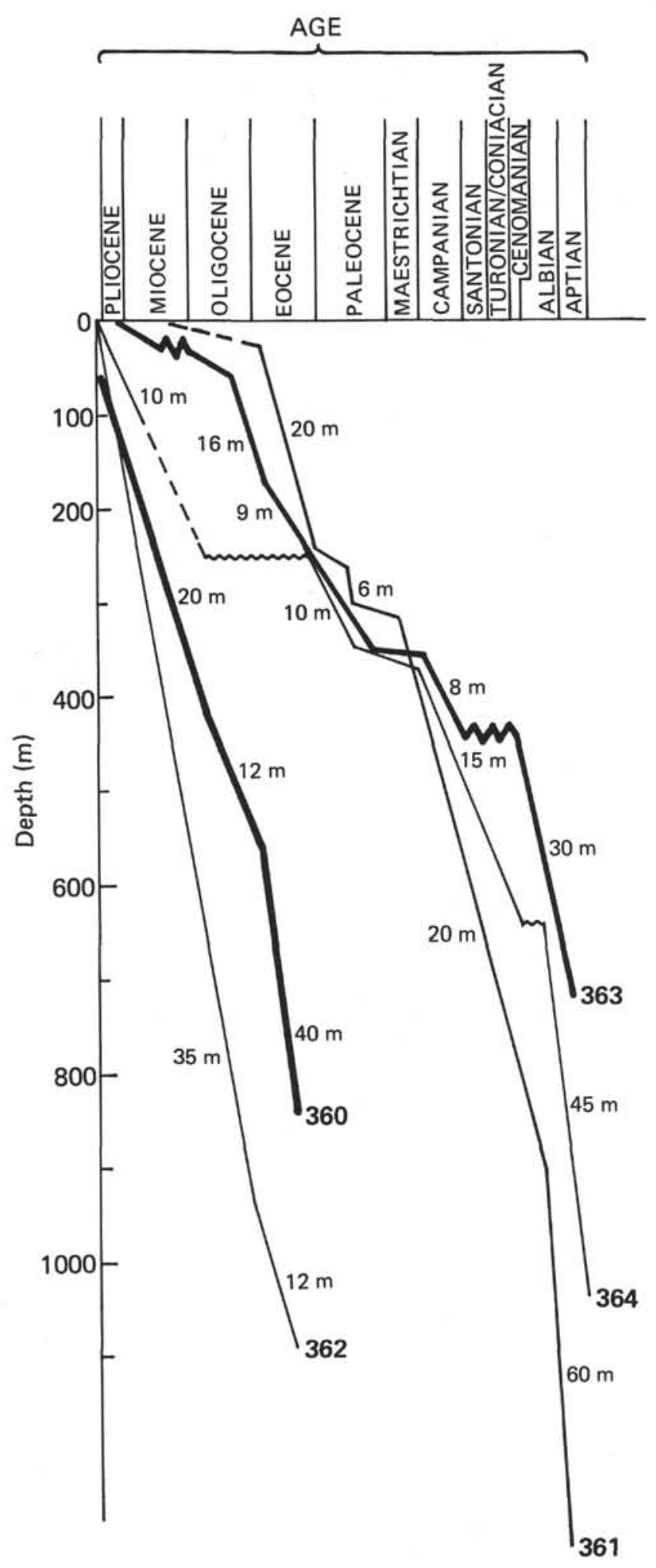

Figure 4. Evolution of sedimentation rates at Sites 360 , $361,362-362 A, 363$, and 364 . shelf to the floor of the basin (see also Kagami, this volume). Furthermore, laminations, graded sequences, and erosional contacts in the sediments suggest that many of them are turbidites.

Beginning in Cenomanian times, the abrupt slowing (from 60 to $20 \mathrm{~m} / \mathrm{m}$.y.) of the sediment accumulation rate corresponds to a decrease of the terrigenous input. At the Cretaceous-Tertiary boundary there is a further drop (from 20 to $6 \mathrm{~m} / \mathrm{m}$.y.) in the rate of accumulation, while sedimentation ceases to be terrigenous and becomes pelagic. The accumulation rate was particularly low $(6 \mathrm{~m} / \mathrm{m} . \mathrm{y}$.) at Site 361 during the Paleocene at which time this site was at or below the $\mathrm{CCD}$. The accumulation rate increased again to approximately $20 \mathrm{~m} / \mathrm{m}$.y. during the Eocene (Figure 4). This high rate is probably related to a drop of the CCD as well as to the presence of turbidites transported from the continental slope down into the deep basin. Then at the end of the Eocene the sediment accumulation rate decreased, partly because of fluctuations of the CCD and partly because of progressive deepening of the site which crossed to a depth below the CCD in the late Eocene.

Because of terrigenous input (Figure 1), the sediment accumulation rate was relatively high $(\approx 40 \mathrm{~m} / \mathrm{m}$.y.) at Site 360 (Figure 4) during middle Eocene time. From then to the early Oligocene the rate decreased to approximately 12 $\mathrm{m} / \mathrm{m}$.y. This drop seems to be the result of an increase of the calcium carbonate dissolution, related to a rise of the CCD. From the middle Oligocene to the Pliocene, the sediment accumulation rate increased to an average of $20 \mathrm{~m} / \mathrm{m}$.y. (Figure 4) with a short decrease in the middle-late Miocene, due again to an increase in calcium carbonate dissolution.

\section{Bathymetric Evolution}

It is now known that the depth of the ocean is governed by the slow cooling of the lithospheric plates as they move away from the ridge crest where they were produced by sea-floor spreading (Langseth et al., 1966; McKenzie and Sclater, 1969). The depth of the ocean depends on its age, as is convincingly demonstrated by the empirical curve (Figure 5) compiled by Sclater et al. (1971) as taken from LePichon et al. (1973). This curve gives the depth of the basement as a function of crustal age. Figures 6-10 show similar curves plotted for several South Atlantic DSDP sites. In deriving these curves, emphasis was put on depths of marly sequences deposited very close to lysocline depths of pelagic clay sequences and of hiatuses encountered at drill sites.

It will be noted that the backtracking traces of the South Atlantic DSDP sites in Figures 6-10 differ in some cases considerably from those of Thiede and van Andel (1977) and van Andel et al. (in press). Since the general subsidence curve is fairly well established and agreed upon (Sclater and Francheteau, 1970; LePichon et al., 1973), the discrepancy arises from backtracking from the present depth in this paper and not from an absolute theoretical depth, as in the others. This is the same approach followed by Sclater et al. (1971) for aseismic ridges and argued by Sleep (1969) to apply to continental margins.

According to the subsidence curve (Figure 6), the depth of Site 361 was close to 1000 meters for the Aptian, 1500 meters for the Albian, 3000 meters for the Maestrichtian, and nearly 3700 meters for the end of the Eocene. A thin bed of upper 


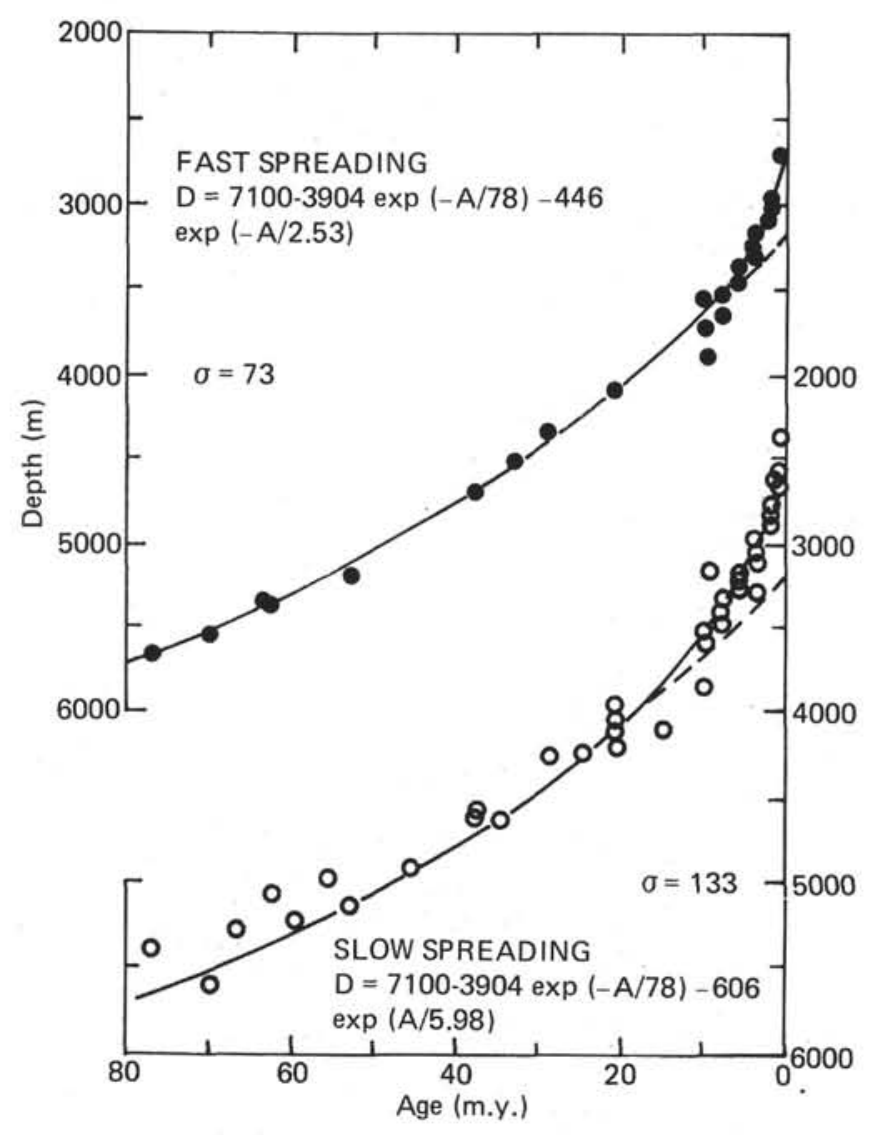

Figure 5. Empirical depth-age curve for the ocean bottom for ages younger than 80 m.y., from LePichon et al. (1973).

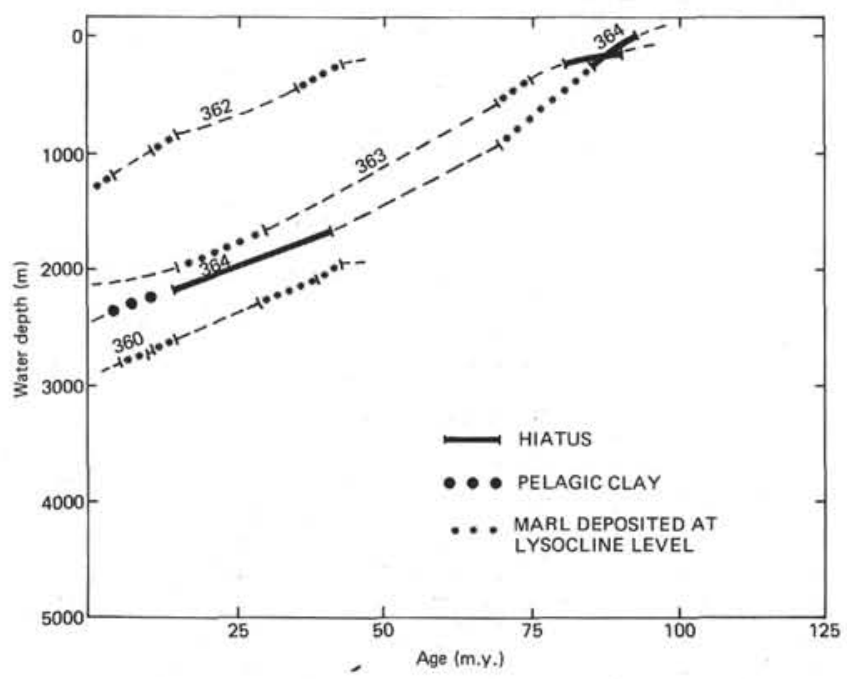

Figure 7. Bathymetric evolution of Sites $362-362 A$ and 363 (Walvis Ridge, Leg 40), of Site 364 (Angola Margin, Leg 40), and of Site 360 (Cape Basin, Leg 40). Hiatuses might indicate change in oceanic circulation. Pelagic clay and marl deposited at or close to the lysocline level are critical indicators of the CCD. Water depth is in meters, age in million years.

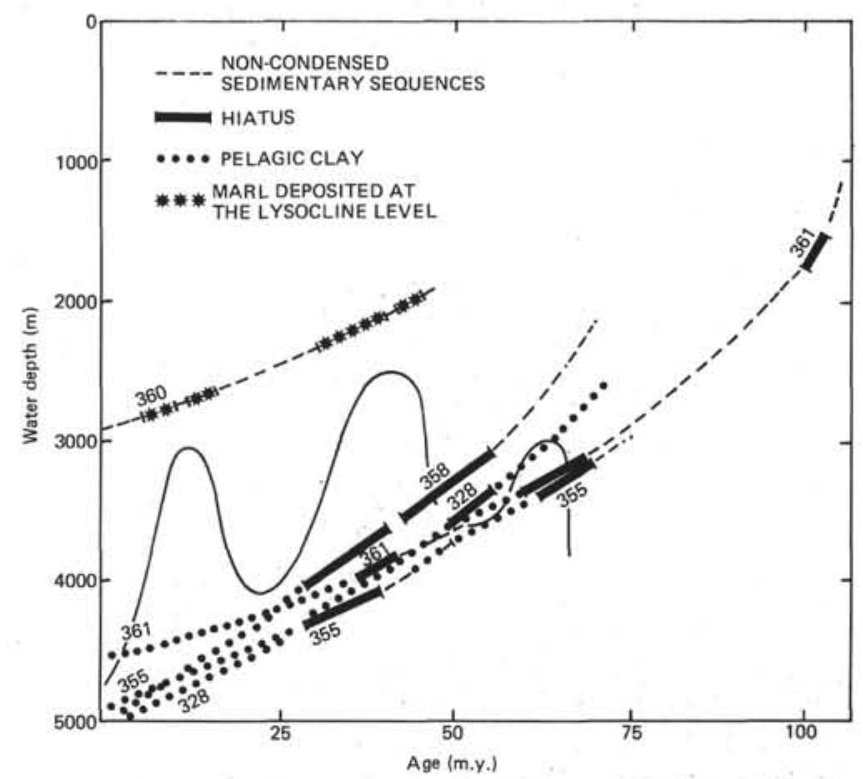

Figure 6. Bathymetric evolution of Sites 355 (Brazil Basin, Leg 39), 360, 361 (Cape Basin, Leg 40), 328, 358 (Argentine Basin, Legs 36 and 39). Hiatuses might indicate changes in oceanic circulation. The CCD curve of the Figure 17 has been drawn in accordance with the bathymetry of representative facies at their time of deposition, such as pelagic clay, marl deposited at the lysocline level, and chalk (average values from Argentine and Cape basins). Water depth is in meters, age in million years.

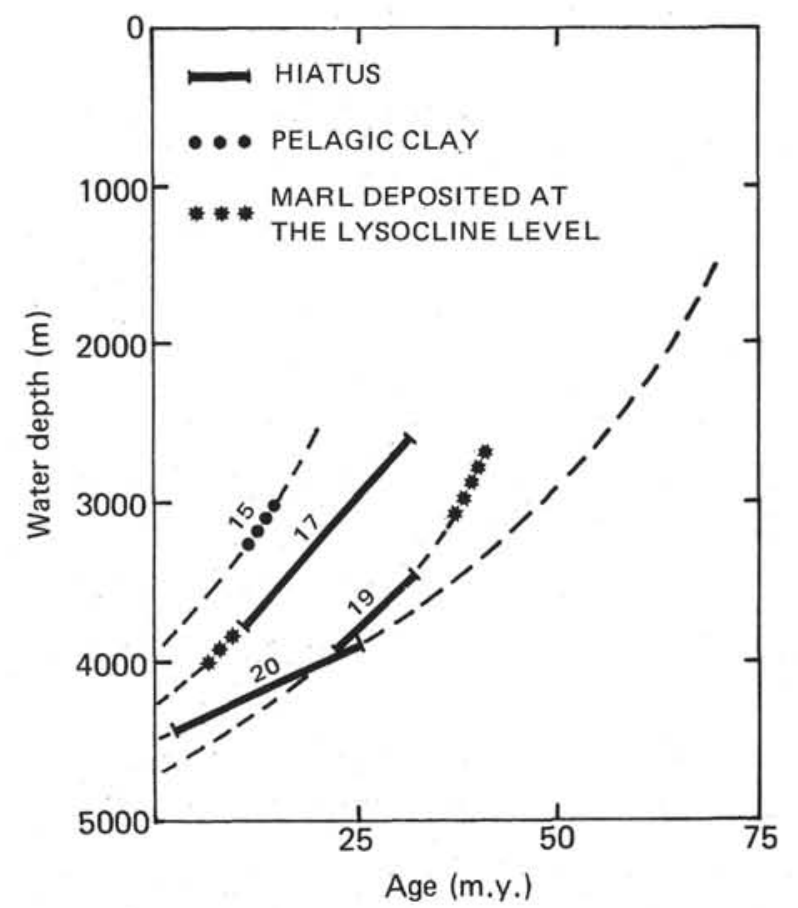

Figure 8. Bathymetric evolution of Sites 15, 17, 19, and 20 (Mid-Atlantic Ridge, Leg 3). Hiatuses might indicate change in oceanic circulation. Pelagic clay and marl deposited at or close to the lysocline level are critical indicators of the CCD. Water depth in meter, age in million years. 


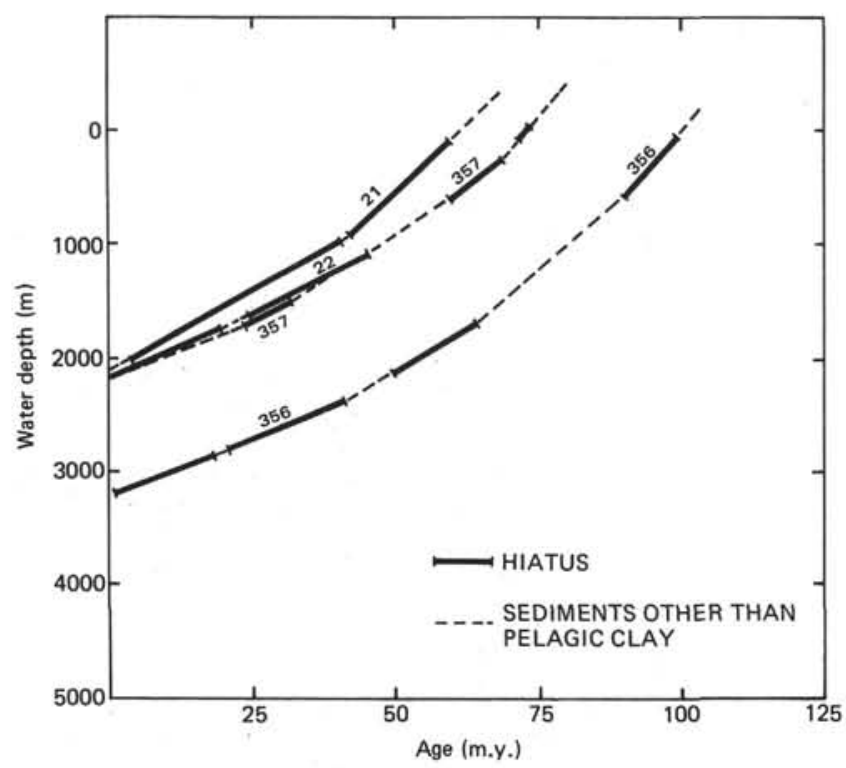

Figure 9. Bathymetric evolution of Sites 21, 22 (Rio Grande Rise, Leg 3), Site 356 (São Paulo Plateau, Leg 39), and Site 357 (Rio Grande Rise, Leg 39). Hiatuses might indicate change in oceanic circulation. Pelagic clay and marl deposited at or close to the lysocline level are critical indicators of the CCD. Water depth in meters, age in million years.

Paleocene chalk was deposited at a depth close to 3600 meters but was very probably reworked from shallower depth. ${ }^{2}$

The bathymetric evolution of Site 360 from the Eocene to the present time is also shown on Figure 6. It, of course, was considerably shallower than Site 361 , as it is today. It was at or near the lysocline level while Site 361 was below the CCD through most of the Tertiary.

\section{Carbonate Dissolution Cycles and the CCD}

As shown in Figure 1, the calcium carbonate content of the Cretaceous sediments is very low. This might be explained, for example, by large-scale dilution with non-carbonate terrigenous sediments. The terrigenous supply, with its high content of organic matter, not only had a diluting effect, but also a dissolving effect. The proof of this is the imprinting of coccoliths in the black shales. The rarity of calcitic remains might also be due to original low levels of carbonate production associated with unfavorable environmental conditions. Periods of oceanic stagnation in the Cretaceous appear to have been accompanied by an important shallowing of the CCD (Ryan and Cita, 1977). Nevertheless, black shales were also deposited during Albian on the Falkland Plateau at a paleodepth close to 1500 meters (Sites 327, 330; Barker,

'Editor's note: The possibility also exists that Site 361 was uplifted in the Paleogene (see Chapter 2, this volume). Since the lowermost sediments of Site 361 were deposited nearly on oceanic basement, backtracking from the present depth would imply a spreading center nearly 1500 meters shallower than occurs on the Mid-Atlantic Ridge at the same latitude today. The Paleogene uplift resolves this unlikely situation, but implies that the CCD was deeper in the Aptian and Albian than the 1000-1500 meters inferred here.

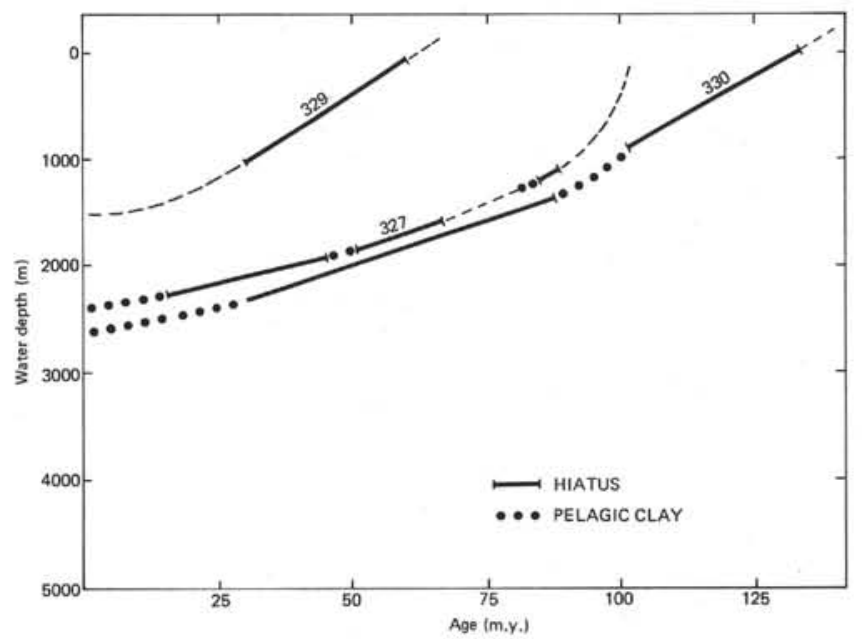

Figure 10. Bathymetric evolution of Sites 327, 329, and 330 (Falkland Plateau, Leg 36). Hiatuses might indicate change in oceanic circulation. Pelagic clay and marl deposited at or close to the lysocline level are critical indicators of the CCD. Water depth in meters, age in million years.

Dalziel, et al., 1974), and these were interbedded with some carbonates. ${ }^{3}$ The CCD at Site 361 in the Cape Basin might have been close to 1500 meters in Aptian-Albian times, but part of the dissolution occurred after sedimentation, and the carbonate particles might have been heavily diluted by abundant terrigenous supply through turbiditic flow. Therefore, the apparent "shallowness" of the Aptian-Albian CCD at Site 361 may to a large extent be a local phenomenon.

In the Paleocene, the presence of pelagic clays, which are characteristic of a dissolution residue, indicates that Site 361 was located either at or below the CCD at that time. Thus, during most of the Paleocene, the CCD must have been close to 3700 meters. In this area, at the end of the Paleocene, there is a chalk layer (Figure 2) at a paleodepth of 3600 meters which could suggest a much deeper CCD, but this chalk seems to have been transported there from a shallower depth.

As previously mentioned, Site 360 offers excellent evidence for calcium carbonate dissolution (Figure 1). Two major dissolution cycles are obvious: middle-upper Eocene and middle-upper Miocene. A third, but shorter one and with a less intensive degree of dissolution can be recognized in the lowermost Oligocene.

With respect to the depth of middle Eocene marls of Site $360(\approx 2000 \mathrm{~m}$, Figure 6 ), we may assume that the middle Eocene lysocline of the Cape Basin was also close to the 2000 meters, and that, therefore, the CCD might have been close to 2500 meters. The shallowing and deepening of the CCD during the Eocene may be linked to the transgression-

'Editor's note: Backtracking from the present depths of Sites 327, 330, and 361 results in the apparent contradiction that the depth of Site 361 (on the deep ocean floor) was no deeper than that of Sites 327,330 (on the Falkland Plateau) in the Aptian using the inferred CCD depths of this paper. This is obviously not possible, but is resolved if a Paleogene uplift affected Site 361. The CCD therefore was at least 1500 meters deep in the Cape Basin at the time, and probably considerably deeper. The lack of foraminifers and poor preservation of coccoliths at Site 361 probably thus resulted in part because Site 361 was deeper than Sites 327, 330. 
regression cycle described for the continental margin of South Africa (Siesser et al., 1974).

The lower Oligocene marls, less affected by dissolution (degree of fragmentation of planktonic foraminifers is $30 \%$ ) than the Eocene marls (at least if, as previously mentioned, we assume that the sedimentary sequences with respect to the CCD were similar during the Eocene to those presently off Brazil (Melguen and Thiede, 1974) were probably deposited between 750 and 1000 meters above the CCD. As their depth was close to 2250 meters (Figure 6), the early Oligocene CCD might have been close to 3000 meters.

Finally, considering that middle Miocene marls were also deposited at the lysocline level (at a depth of about $2500 \mathrm{~m}$, Figure 6) we may assume that the middle Miocene $C C D$ was close to 3000 meters.

From the middle Miocene to the present time there has been an abrupt drop in the CCD to its current position (i.e., $5200 \mathrm{~m}$, according to Ellis and Moore, 1973).

\section{Walvis Ridge, Sites 362 and 363, Lithologic Units}

Walvis Ridge is situated between the Cape Basin and the Angola Basin (Figure 2) and acts as a barrier for the deep cold-water masses flowing from the Antarctic to the north. Only small channels cut in its southernmost part allow a small part of the Antarctic bottom water to enter from the Cape Basin into the Angola Basin (Shannon and Van Ryswijck, 1969; Connary, 1972; Connary and Ewing, 1972). Two sites (363 and 362-362A, Figure 2) were drilled on its eastern extremity. At Site 363, Cretaceous and lower Tertiary sediments were recovered, and at Site 362 Tertiary and younger sediments were recovered. These sediments are discussed below, from the oldest sediments at Site 363 to the youngest sediments at Site 362 in that order.

\section{Site 363}

Site 363 was drilled on a topographic high of the northern flank of the Walvis Ridge. As it was a peak subject to currents flowing across the ridge system, the depositional history of this site is represented by a condensed section of biogenic material with several major hiatuses, representing erosional events. Site 363 was drilled in 2248 meters of water to 715 meters sub-bottom. As previously mentioned, a section ranging from Aptian to middle Miocene was obtained.

Three lithologic units were defined at Site 363 (Chapter 3, this volume). From the bottom to the top (Figure 10) these are:

\section{Unit 3}

Limestones and calcarenites, upper Aptian, 715-696 meters (Cores 40 and 39).

This unit consists of light brownish gray massive foraminiferal limestones with intercalations of small lenses of calcarenites (calcareous sandstone).

The carbonate content is high $(\approx 80 \%$; Appendix A, Figure 2 ) and consists of planktonic foraminifers $(\approx 15 \%)$, a few coccoliths, and mostly (60-70\%) unspecified calcareous particles. A few calcareous algae have been also found in the limestones and could reflect a relatively shallow Aptian environment. This hypothesis was confirmed by the presence in the same sediments of a benthic foraminiferal assemblage of neritic character (Chapter 3, this volume).
Because of limestone induration, it was not possible to sieve the sand fraction (cf. Figure 2). In thin sections, however, this fraction amounts to $10 \%$ to $20 \%$ of the sediments and consists mainly of well-preserved planktonic foraminifers. There are no sand size terrigenous particles. No observations were made on calcareous nannofossils in this lithologic unit.

\section{Unit 2}

Limestones, marly limestones to marly chalk, sapropels, upper Aptian/middle Albian-Campanian, 677-373 meters (Cores 38-21).

This lithologic unit differs from Unit 3 by a general decrease of total carbonate, the presence of abundant laminations throughout the more marly sequences, and the disappearance of microfaunas or microfloras of neritic character.

This unit consists of cyclically bedded marly limestone or marly chalk and heavily bioturbated limestone. The distribution of each lithologic type is given by the facies distribution, and by the carbonate content fluctuations (Figure 2). Fluctuations in the carbonate content throughout this unit (Appendix A) seem to be related to pulsations of terrigenous material: clay quartz, and micas. This material is very fine, as shown by the very low proportion (1-6\%) of the sand fraction, and by the composition of this fraction. Clastic components, which form from $5 \%$ to $20 \%$ of the sand fraction are represented by micas only (Figure 2 ). This reflects a great distance of the site from the terrigenous source. Fluctuations in the abundance of planktonic foraminifers are probably related to dilution by terrigenous material.

In the lower part of this unit, particularly in Core 26, pyritiferous sapropel was encountered, as 2- to 4-cm-thick layers in late Albian sediments. These sapropel layers are similar to the sapropels found in the eastern Mediterranean Sea (CNEXO cruise Polymede II, Messinian Abyssal Plain). in Quaternary sedimentary sequences. They reflect the intermittent presence of conditions of stagnation in the Angola Basin. As will be shown later, these conditions of stagnation existed at the same time along the Angola margin (cf. Site 364) and disappeared near the end of the Coniacian. The appearance of sapropels at Site 363 is marked by a decrease of approximately $20 \%$ in the carbonate content due to an increase in carbonate dissolution (increase of $20 \%$ or more in the degree of fragmentation of the planktonic foraminifers), and to a decrease in the benthic productivity.

The Campanian is characterized by a decrease of the carbonate content due to an increase in terrigenous components (especially of quartz; Figure 2) and to an increase of carbonate dissolution (cf. fragmentation of planktonic foraminifers, Figure 2).

\section{Unit 1}

1 Foraminiferal/nannofossil chalk and ooze to marly ooze, Maestrichtian, to middle Miocene, 373-31 meters (Cores 21-1).

Unit 1 differs from Unit 2 in having a higher calcium carbonate content (Appendix A, Figure 2) and by the astonishing presence of Braarudosphaera ooze. The calcium carbonate increase is related to a drastic decrease both of the carbonate dissolution and of terrigenous input. Two sedimentary sequences, however, are still obviously affected by 
dissolution: the Cretaceous/Tertiary boundary (Cores 21-18, 373-325 m) and the lower Oligocene (Core 8, 173-164 m). These periods of increased dissolution are well reflected by the maxima of fragmentation of planktonic foraminifers (Figure 2). Both events are very probably related to a rise of the CCD. A sharp rise of the CCD was apparently worldwide at the Maestrichtian-Paleocene boundary (Worsley, 1974). At that time, Site 363 was probably situated close to the lysocline (see Figure 2). Later, during part of the lower Oligocene (Core 8, 173-164 m), the site was well below the lysocline as shown by the high degree $(\approx 90 \%)$ of fragmentation of planktonic foraminifers and the relative abundance $(\approx 10 \%)$ of benthic foraminifers and of fish debris $(\approx 2 \%)$.

Toward the top (middle Oligocene/lower Miocene) of this unit, a slight decrease in the carbonate content (Figure 2; Cores 5 to 2 ) is related, not to carbonate dissolution (cf. very low degree of fragmentation of planktonic foraminifers) but to an increased input of fine $(<63 \mu \mathrm{m})$ terrigenous material.

The most striking characteristic of this unit is the presence of pure white nannofossil ooze, occurring as $2-$ to $60-\mathrm{cm}$ thick layers intercalated between light gray to orange foraminiferal nannofossil chalk. This white and very soft nannofossil ooze contains up to $90 \%$ calcium carbonate, almost entirely constituted of Braarudosphaera pentaliths (entire or fragmented). It is astonishing that this pure Braarudosphaera ooze contains almost no other nannofossil than Braarudosphaera (a few placoliths and rare Discoasters excepted) and almost no benthic or planktonic foraminifers, as shown by the disappearance of the sand fraction in Core 7 (Figure 2). It is difficult to explain the formation of Braarudosphaera ooze in the open ocean (Saito and Percival, 1970). As the Oligocene "Braarudosphaera chalk" in the South Atlantic is widely distributed and associated with bathyal microfaunas, we may assume that it reflects neither ocean shelf conditions nor a restricted environment (Bukry, 1974), but rather some prolonged ecological effect such as reduction of the salinity of the South Atlantic near-surface waters favoring prolonged blooms of phytoplankton.

\section{Sites 362-362A}

Sites 362-362A are located on the Abutment Plateau of the Frio Ridge segment of the Walvis Ridge where the ridge adjoins the continental margin of southwest Africa (Figure 2 ). Two holes were drilled, Hole 362 , which terminated at 806 meters sub-bottom, and Hole $362 \mathrm{~A}$ which was abandoned at 1081 meters sub-bottom. The penetrated section extends from Holocene to lower Eocene. Four lithologic units are recognized (Chapter 3 , this volume) from bottom to top.

\section{Unit 4}

Marly nannofossil chalk to limestone, lower upper Eocene, 1081-919 meters, Cores 362A-12 to 362A-5.

This unit consists predominantly of greenish gray to light gray limestone, massive or laminated, and coarse calcarenite. The calcium carbonate content is high $(70-80 \%$, Appendix A, Figure 2) and consists of calcareous nannofossils (5-20\%) and unspecified carbonate particles (60-75\%). Benthic and planktonic foraminifers are the dominant constituents of the sand fraction (Figure 2). They are well preserved (as noted in thin sections because of the strong recrys- tallization of the sediments). This Eocene calcarenite was deposited as turbidites, and then strongly affected by diagenesis, reflected in the abundance of unspecified carbonate particles and the strong recrystallization of the foraminifers. Terrigenous input was very limited and no trace of it appears in the sand fraction (Figure 2).

\section{Unit 3}

Braarudosphaera chalk and marly nannofossil chalk, lower Oligocene, 919-843 meters (Cores 362A-5 to 362A3).

The Braarudosphaera chalk occurs as thin light gray soupy layers intercalated in marly nannofossil chalk sequences (Figure 2). Compared with Site 363, Sites 362-362A contain fewer, thinner Braarudosphaera chalk layers. Marly chalk beds are more compact and contain moderately to well-preserved planktonic foraminifers (degree of fragmentation $=20-25 \%$, Figure 2).

\section{Unit 2}

Foraminifer-nannofossil chalk to marly nannofossil chalk, middle Oligocene-upper Miocene, 843.5-207 meters (Cores $362 \mathrm{~A}-3$ to $362-16$ ).

This lithologic unit is characterized by well-bedded nannofossil chalk sequences associated with cyclic intercalations of marly chalk (Figure 2). It is marked by the disappearance of the Braarudosphaera chalk, and is also characterized by:

1) an increase of the primary productivity during the lower Miocene, reflected in the relative abundance of benthic foraminifers and fish debris, associated with well-preserved planktonic foraminifers (Figure 2).

2) an increase in carbonate dissolution during the middle-upper Miocene, reflected in the relative abundance of benthic foraminifers and fish debris, which are associated with moderately fragmented planktonic foraminifers (Figure 2, fragmentation: $30-40 \%$, the site was located above the lysocline).

3) the appearance of siliceous microfossils (radiolarians) in the upper Miocene (Figure 2). The association of siliceous microfossils, benthic foraminifers, and abundant (but heavily fragmented) planktonic foraminifers (Figure 2) points to a net increase in the primary productivity.

4) intensive bioturbation, probably related to the high fertility.

5) the absence of sand-size terrigenous particles. Terrigenous material is present, but represented only by 15 to $25 \%$ clay minerals.

6) the presence of laminations and erosional contacts reflecting the presence of bottom currents.

\section{Unit 1}

Diatomaceous marly nannofossil ooze and radiolarianbearing chalk, Pliocene-Pleistocene, 207-36 meters (Cores 16-1).

This unit has particularly abundant and well-preserved Pleistocene siliceous microfossils (Figure 2). This may be due either to a change in cold current patterns or to differential dissolution within the sediments. In a possibly comparable case, siliceous microfossils have been completely destroyed by differential solution in the upper $50-70 \mathrm{~cm}$ of sediments off Portugal and Morocco within about 4000 years 
(Schrader, 1971a, b). At Site 362 the increase of oceanic fertility at the end of the Cenozoic increased the amount of organic matter present in the sediments and, consequently, the degree of calcium carbonate dissolution within the sediments. This is reflected by the high degree of fragmentation (70-90\%) of planktonic foraminifers (Figure 2), suggesting sediment deposition well below the lysocline. This is confirmed by the degree of dissolution of the calcareous nannofossils (Noël and Melguen, this volume).

\section{Sediment Accumulation Rates}

Sediment accumulation rates for the Aptian/Albian deposits at Site 363 are high ( $>40 \mathrm{~m} / \mathrm{m}$.y.; Figure 4$)$ and reflect a high biogenic productivity associated with intermittent pulsations of terrigenous material. The lowest rate $(\approx 1.5$ $\mathrm{m} / \mathrm{m} . \mathrm{y}$.) corresponds to an interval across the Cretaceous/ Tertiary boundary and is related to a sharp rise of the CCD. Eocene accumulation rates were relatively slow $(\approx 9 \mathrm{~m} / \mathrm{m}$.y.) because of current activity. Oligocene rates were higher (16 $\mathrm{m} / \mathrm{m} . \mathrm{y}$.), but were normal for an oceanic ridge and comparable to the sediment accumulation rate observed through the same time interval at Sites 362-362A (Figure 4) in the adjacent high-standing trough of the Walvis Ridge.

Figure 4 shows that the sediment accumulation rate at Sites $362-362 \mathrm{~A}$ rose from $12 \mathrm{~m} / \mathrm{m} . \mathrm{y}$. during middle Eocene/early Oligocene to $35 \mathrm{~m} / \mathrm{m}$.y. during the middle/late Oligocene, and then stayed remarkably uniform until the Pliocene. During the Pliocene, in spite of the increasing oceanic fertility, the sedimentation rate dropped to $10 \mathrm{~m} / \mathrm{m}$.y., as the terrigenous input decreased. The highest sediment accumulation rate (middle Oligocene/Pliocene) is related to a net increase in the terrigenous input, and to the deposition of marly deposits. Note that the Oligocene rates at Sites 362-362A are comparable to those observed for the same time interval at Site 363 .

\section{Bathymetric Evaluation}

The bathymetric evolution of Site 363 from the upper Aptian to the middle Miocene is presented in Figure 7. The emphasis is on the bathymetry of specific levels, such as the Albian/Turonian hiatus or the Maestrichtian/Paleocene and the lower Oligocene foraminiferal nannofossil chalk (which was obviously affected by carbonate dissolution, and was probably deposited close to the lysocline level). Figure 7 shows that the first hiatus (Albian-Turonian) took place as the site was at approximately 300 meters water depth and the second hiatus (lower/middle Miocene) close to 2000 meters. The dissolution levels (Maestrichtian/Paleocene and lower Oligocene) were at about 500 and 1800 meters, respectively.

Sites $362-362$ A were very shallow $(\approx 200 / 300 \mathrm{~m}$ ) during the middle/late Eocene, and close to 1000 meters during the Miocene.

\section{Carbonate Dissolution Cycles and the CCD}

As mentioned earlier two levels of carbonate dissolution can be recognized at Site 363. Based on the carbonate content (70-80\%) of the sediments, and the degree of fragmentation of the planktonic foraminifers, these sediments were deposited close to the lysocline. In this case the CCD would have been close to 1000 meters at the Cretaceous/Tertiary boundary, and close to 2300 meters during the lower Oligocene. These values are much shallower than the average CCD values known for the Atlantic Ocean at that time (Ramsay, 1974; Berger and Roth, 1975). This might be explained by the fact that Site 363 is located close to an area of upwelling and that the carbonate dissolution was accelerated by the presence of abundant organic matter in sediments deposited during periods of high oceanic productivity. Therefore, the rise of the CCD could have been a very local phenomenon. The same effects are well known today in the South Atlantic, where the CCD is much higher in areas of high oceanic fertility (Falkland Plateau) than in the adjacent basins (Argentine and Cape basins; Figure 11).

In spite of the evidence of net fluctuations in the degree of carbonate dissolution in the sedimentary sequence of Sites $362-362 \mathrm{~A}$, the sediments were too shallow (Figure 7) to give much information about the Eocene-Pleistocene CCD of the South Atlantic. Like Site 363, the sites are located in an upwelling area with sediments rich in organic' matter and consequently have high carbonate dissolution. Therefore, even if the degree of planktonic foraminifer fragmentation (Figure 2) indicates that this site was probably close to the lysocline during part of the lower Oligocene and the middleupper Miocene, the depth of the lysocline obtained there concerns only this area of upwelling and is not representative of the whole South Atlantic.

\section{Angola Margin, Site 364, Lithologic Units}

Site 364 was drilled into the lowest part of the Angola continental rise, in 2448 meters of water (Figure 3). Eight lithologic units are recognized (Chapter 4 , this volume).

\section{Unit 8}

Marly dolomitic limestone with sapropel, upper Aptianmiddle Albian, 1086-967 meters (Cores 46-39).

This unit consists of light bluish gray dolomite to olivegray marly dolomitic limestone, with intercalations of black sapropelitic shales. The carbonate content varies from $3 \%$ in the sapropel to $90 \%$ and more in the limestone (Figure 3). The carbonate content of the sapropel is very low because of low primary productivity due to euxinic conditions, but also because of extensive dissolution related to the presence of abundant organic matter. Most of the carbonates are pure dolomite (Siesser and Bremner, this volume; Matsumoto et al., supplemental volume). In smear slides, the dolomites consist mainly of dolomitic rhombs and of unspecified carbonate particles.

\section{Unit 7}

Marly limestone, Albian, 967-710 meters (Cores 38-26). This unit consists of greenish gray to reddish brown marly limestone to marly chalk, with intercalations of light bluish gray limestone. The abundance of laminations in the marly limestone is related to cyclic input of fine terrigenous material: essentially clay minerals and micas. With the exception of a few micas the sand fraction consists exclusively of planktonic foraminifers (Figure 3). Their degree of fragmentation is generally low (2-20\%). In a few cases the fragmentation exceeds $40 \%$ and is probably related to the presence of minor layers of sediment (sapropels) rich in organic matter. However, the middle-late Albian does not appear to have been a period of high oceanic productivity; benthic foraminifers and fish debris are rare and there are no siliceous microfossils (Figure 3). 

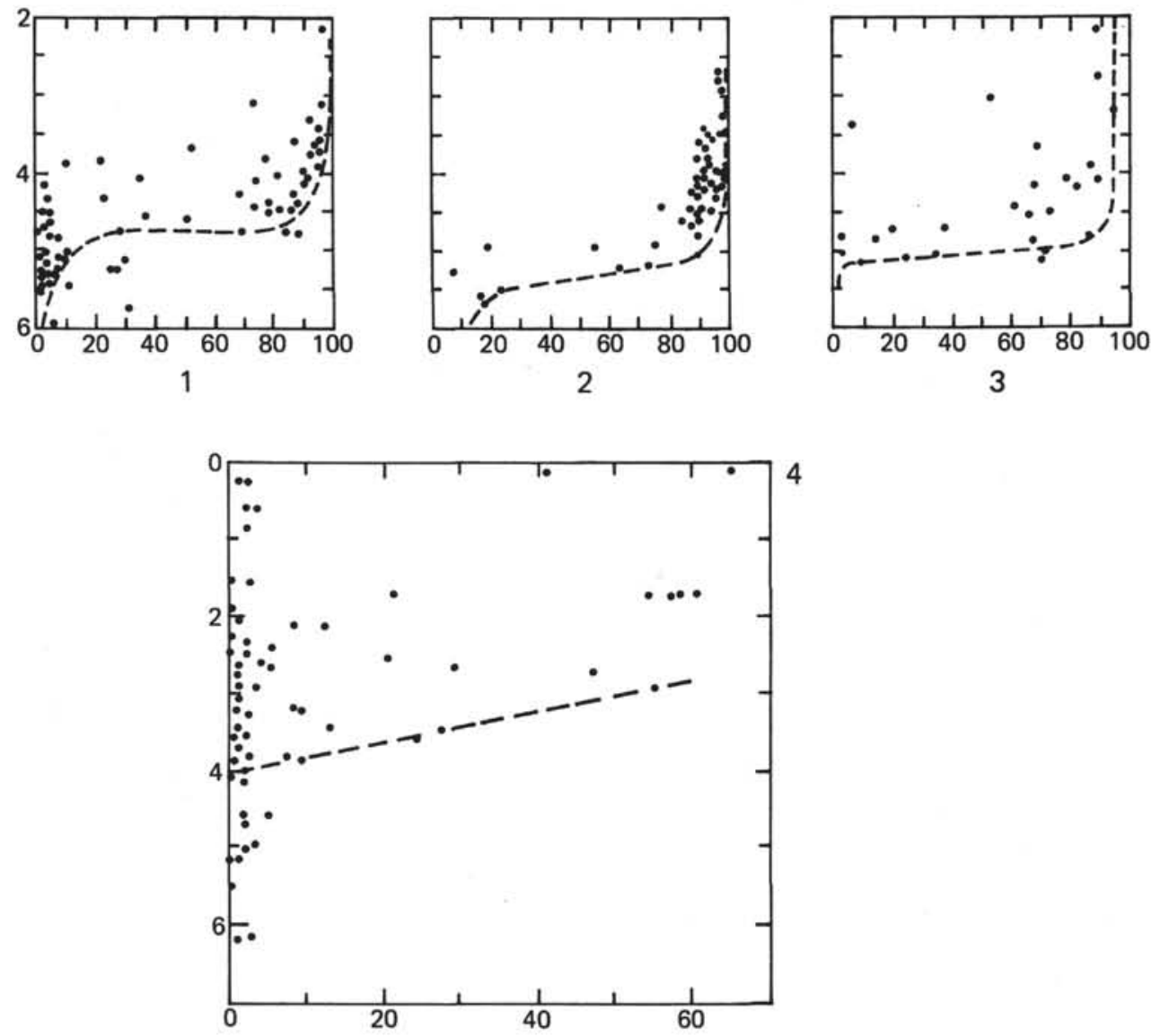

Figure 11. Calcium carbonate content in surface sediments of the South Atlantic Ocean in percent versus water depth in kilometers; 1, 2, 3, Argentine and Brazil basins, Angola Basin, and Cape Basin, respectively, after Ellis and Moore (1973), 4 Faulkland Plateau and $50^{\circ} \mathrm{S}$, after Biscaye et al. (1976).

\section{Unit 6}

Marly dolomitic nannofossil chalk with sapropel, upper Albian, upper Turonian-Campanian, 710-480 meters (Cores 25-16).

Sapropel layers are limited to the lower part of this marly sequence and indicate that euxinic conditions prevailed in the Angola Basin until the Coniacian/Santonian. The Santonian/Campanian marks the installation of welloxygenated oceanic conditions favoring the development of bottom life, clearly reflected by the intensity of the bioturbation affecting the chalk and marly chalk layers, and by the color of these layers: light brown to brown and reddish brown. At this time the ocean achieved a state of interchange of shallow and deep waters, allowing the accumulation of normal pelagic calcareous sediments. It very probably corresponds with the opening of the Brazil and Angola basins to the north. This opening is clearly reflected in the sediments drilled, for example, on the flank of the Walvis Ridge (Site 363), on the Rio Grande Rise (Site 357), and on the São Paulo Plateau (Site 356; Perch-Nielsen, Supko, et al., 1975). At these sites, marls with sapropel layers ar overlain by Campanian chalks. This evolution is characterized by a progressive increase of the carbonate content, corresponding to a general increase of the oceanic fertility, as reflected in the relative abundance of benthic and planktonic foraminifers, of fish debris (Figure 3) and in the appearance of radiolarians in the sediments (Appendix B).

In this unit calcium carbonate fluctuations are great and are explained either by intermittent dilution with non-calcareous terrigenous material, or by intermittent intensive dissolution (within sapropel layers) during euxinic conditions. Euxinic conditions are reflected in the abundance (2-90\%) of pyrite (Appendix B, Cores 33, 31, 25, 24, 23, 22). Where evidence for these euxinic conditions disappears, calcareous microfossils are relatively well preserved (only $10-20 \%$ fragmentation in the Santonian-Campanian chalk, Figure 3).

\section{Unit 5}

Nannofossil chalk, Campanian-Maestrichtian, 480-368 meters (Cores 15-12).

This short unit does not differ from the top of the preceding one, except it has a higher carbonate content and is more homogeneous (Figure 3). The carbonate content varies from $55 \%$ to $70 \%$ (Appendix A).

\section{Unit 4}

Marly nannofossil chalk, Maestrichtian-lower Eocene, 368-283 meters (Cores 11-8).

This unit differs from Unit 5 in the presence of marls and mudstones reflecting a higher terrigenous input (Figure 3). Furthermore, the benthic foraminifer frequency increases 
drastically ( 50 to $80 \%$ of the sand fraction). Both characteristics probably indicate that at least some of the Maestrichtian-Paleocene sediments are allochthonous and have been transported from the continental slope. Paleocene/lower Eocene sediments also contain high frequencies $(>40 \%)$ of benthic foraminifers, which are either the only calcareous remains of the sand fraction or are associated with heavily fragmented planktonic forminifers (Figure 3). In both cases they indicate a high degree of carbonate dissolution. Dissolution increases from lower Eocene to middle Eocene.

\section{Unit 3}

Radiolarian mud/pelagic clay, middle Eocene-upper Miocene 283-75 meters (Cores 7-4).

This unit, which consists of radiolarian mud and pelagic clay (Figure 3) differs from Unit 2, mainly in its much lesser proportion of carbonate sediments. Furthermore, middle Eocene sediments are characterized by a drastic enrichment in radiolarians, which constitute up to $95 \%$ of the sand fraction (Appendix B). This enrichment indicates an important increase of the oceanic fertility. Increase in the oceanic fertility also characterizes the middle/upper Miocene sediments, as reflected in their relatively high abundance (15$50 \%$ ) in fish debris.

The increase of the primary productivity led to an enrichment of the sediment in organic matter and, consequently, to an increase of carbonate dissolution, reflected by the high degree of fragmentation of planktonic foraminifers (Figure 3 ). There is also a relative increase of the terrigenous material (5-40\% micas; $5-80 \%$ quartz) in the sand fraction. The intermittent absence of calcareous biogenous particles and of fish debris in the sand fraction is explained by a decrease of the primary productivity and a drastic increase in carbonate dissolution.

\section{Unit 2}

Marly nannofossil ooze, lower Pliocene, 75-50 meters (Core 3).

This lithologic unit is represented only by Core 3 . Compared with Unit 3, the sediment is characterized by a drastic increase $(>30 \%)$ of the carbonate content related both to a decrease of the terrigenous material (Figure 3 ) and to an increase of the surface-water productivity. The relative abundance of pyrite (10-20\% of the sand fraction) indicates the presence of reducing conditions.

\section{Unit 1}

Calcareous mud, upper Pliocene-Pleistocene, 7.5-45.5 meters (Cores 1-2).

The dark olive-gray color of this uppermost unit of Site 364 is typical of areas with high oceanic fertility. The relative abundance of benthic foraminifers (Figure 3) is probably related also to high fertility. However, fish debris is normally a good indicator either of high oceanic fertility such as in areas of upwelling (Sheldon, 1964; Berger and Von Rad, 1972) or of heavily dissolved sediments in areas of low sedimentation rate. The rare fish debris in the present case could be partly explained by dilution with terrigenous material (mainly micas and clay minerals). Masses of terrigenous material could easily be transported to the continental rise through submarine canyons, which were clearly detected on Glomar Challenger seismic profiles. Equally characteristic of high fertility areas are the siliceous microfossils, which are, however, rapidly removed. Finally, this unit has abundant pyrite ( 3 to $55 \%$ of the sand fraction; Appendix B) and no burrows, both suggesting fairly stagnant bottom conditions.

\section{Sediment Accumulation Rates}

Figure 4 shows that the Lower Cretaceous sediment accumulation rate at Site 364 was very fast ( $\approx 45 \mathrm{~m} / \mathrm{m} . \mathrm{y}$.), indicating a high planktonic productivity in spite of intermittent euxinic conditions. The rate was also high because of intermittent massive input of fine terrigenous material, leading to thick marly chalk layers. For the Upper Cretaceous the mean rate drops to approximately $15 \mathrm{~m} / \mathrm{m}$.y., reflecting the presence of a sedimentary hiatus (Cenomanian-Turonian) and a drop in ocean fertility, again related to euxinic conditions. These oceanic conditions controlled not only primary productivity but also carbonate dissolution: periods of sapropel deposition were also periods of carbonate dissolution (Figure 4), at least at Site 364. Near the MaestrichtianPaleocene boundary, the sedimentation rate continued to decrease because of increasing carbonate dissolution. This drastic drop in the sediment accumulation rate at this time is a world wide phenomenon as discussed above for the Cape Basin and Walvis Ridge.

The Paleocene-lower Eocene is, on the contrary, marked by an increase in the sediment accumulation rate to 10 $\mathrm{m} / \mathrm{m}$.y., related to a net increase of terrigenous material, associated with a decrease in the carbonate dissolution. A major hiatus ( $\approx 20 \mathrm{~m} . \mathrm{y}$.) extends from the middle Eocene to the middle/upper Miocene within the pelagic clay sequence (Figure 3) and can be explained either by intermittent nondeposition and intensive carbonate dissolution, or by erosional effects. Finally, the upper Miocene/Pleistocene sequence is characterized by a mean sedimentation rate of 10 $\mathrm{m} / \mathrm{m} . \mathrm{y}$., a value which is not far from those deduced for the same time interval at Sites 360 and 362-362A.

\section{Bathymetric Evolution}

The bathymetric evolution of Site 364 is presented on Figure 7. During the upper Aptian/Albian Site 364 was extremely shallow, covered only by a few tens to a few hundreds of meters of water. The relative abundance of dolomitic limestone (60-90\% of the sediment) at the base of the hole is probably related to this very shallow water depth. This agrees with the fact that upper Aptian dolomitic limestones are deposited just above evaporites, as indicated by the very high interstitial salinity of interlayered shales. The progressive subsidence of the site resulted in a water depth close to 500 meters for the Santonian, 1000 meters for the Maestrichtian/Paleocene boundary, 1500 meters for the middle Eocene, and 2200 meters for the middle/upper Miocene.

The bathymetric evolution of Site 364 is very similar to that of Site 363; both sites were extremely shallow during the Aptian/Albian (Figure 7).

\section{Carbonate Dissolution Cycles and the CCD}

As previously mentioned for Sites $362-362 \mathrm{~A}$ and 363 , Site 364 was too shallow to have been affected by the general 
fluctuations of the South Atlantic CCD since the Early Cretaceous. Following the fluctuations of the degree of fragmentation of planktonic foraminifers (Figure 3), it appears that, with the exception of the sapropel layers, carbonate dissolution was very low (degree of fragmentation $<20 \%$ ) throughout. Only intermittent periods of euxinic conditions (upper Aptian, upper Albian, Coniacian/Santonian) are characterized by a drastic rise of the CCD up to the surface water masses of the middle Eocene and middle-upper Miocene, as they did in the Cape Basin. The cycles were, in fact, major shallowings of the $\mathrm{CCD}$, which, as mentioned above, reached 2500 and 3000 meters, respectively, in the Cape Basin. At Site 364, however, the CCD rose to 1500 meters during the middle Eocene and to 2000 meters during the middle Miocene, because of the high fertility of this area. These CCD depths are not relevant to the entire Angola Basin.

The same explanation can be given for the intermittent high carbonate dissolution (fragmentation of planktonic foraminifers: 60 to $100 \%$ ) encountered in the upper Miocene/Pleistocene sedimentary sequence.

\section{SEDIMENTARY FACIES EVOLUTION OF THE EASTERN SOUTH ATLANTIC SINCE EARLY CRETACEOUS}

\section{Cretaceous}

The Early Cretaceous along the eastern South Atlantic was characterized by deposition of salt, installation of stagnant basins having euxinic bottom conditions, intensive carbonate dissolution, and drastic sedimentation rates, related to humid climatic conditions. Salt deposition, which was restricted to the North of the Walvis Ridge (Leyden et al., 1976) and ceased during the early late Aptian, shows that the climate was relatively dry and warm in Angola at that time. In the Cape Basin, on the contrary, the very thick sapropelic black shales intercalated in massive sandstones rich in plant debris (partly turbidites), probably indicate humid conditions favoring not only luxuriant plant growth in South Africa, but also extensive erosion. ${ }^{4}$ Shales and sandstones filled the Cape Basin at an incredible rate of over $60 \mathrm{~m} / \mathrm{m} . \mathrm{y}$. Euxinic conditions prevailed in the Cape Basin throughout the Aptian/ Albian and ceased at the end of the Early Cretaceous, while they persisted intermittently in the Angola Basin until the Coniacian/Santonian. Thus it is obvious that at this time the Walvis Ridge was acting as a barrier between two basins. Stagnant conditions were intermittent in the Angola Basin, allowing periods of oxygenation of the bottom waters and the deposition of limestones or marly limestones, more or less dolomitic. Throughout the Lower Cretaceous, sedimentation was less terrigenous and therefore, much more calcareous and pelagic in the Angola Basin and on the Walvis Ridge than in the Cape Basin.

During the Late Cretaceous, the terrigenous influence, however, decreased drastically everywhere along the eastern South Atlantic reflecting a significant decline in the denudation and erosion of the African continent. The climate was

\footnotetext{
'See Maclachlan and Pieterse, this volume, and Natland, this volume, for a different interpretation.
}

becoming less humid. The sedimentation rate decreased drastically, particularly around the Cretaceous/Tertiary boundary where it dropped to 1.5 to $6 \mathrm{~m} / \mathrm{m}$.y. in both basins. The Late Cretaceous also saw the disappearance of stagnant bottom waters and the final installation of open oceanic conditions in both basins. This important event in the evolution of the South Atlantic is related to the opening of the Brazil and Angola basins to the north, and to the establishment of the South/North Atlantic communication. The circulation of well-oxygenated waters led to an explosion of pelagic life and consequently, to the deposition of highly calcareous pelagic sediments, such as, for example, the Maestrichtian chalks.

\section{Tertiary}

As previously mentioned the Cretaceous/Tertiary boundary is characterized by a drastic drop of the sedimentation rate, due in part to a general decrease of the terrigenous input, but overall to a worldwide rise of the CCD (Worsley, 1974). The sharp CCD rise is well illustrated in the Cape Basin by the sequence of Paleocene pelagic clays (Site 361, Figure 1). These pelagic clays are followed by lower Eocene marls (Sites 361 and 360), which reflect a drop of the CCD at that time. From the lower Eocene onwards, there is a general increase of the sedimentation rate to a mean value of $10-20$ $\mathrm{m} / \mathrm{m}$.y. This value is relatively uniform for all sites (Figure 5) throughout the Tertiary. The type of sedimentation differs, however, from one site to another, depending both on depth and location south or north of Walvis Ridge. Tertiary sedimentation along the Cape margin (Site 360) is largely dominated by chalk or calcareous oozes, devoid of siliceous microfossils, and reflecting only a minor terrigenous influx, except during the middle-late Eocene, where the deposition of marls at Site 360 indicates an increase of terrigenous input, which may be linked to the transgression-regression cycles observed along the South African continental margin at that time (Siesser et al., 1974).

Along the Angola Margin and on the easternmost part of the Walvis Ridge, on the contrary, sedimentation is characterized by a much greater terrigenous influx and by the presence of siliceous microfossils. As the terrigenous material is supplied essentially by the Congo River, the Oligocene doming of its source region could be responsible for the net increase of terrigenous influx at that time. Later on, during the Pleistocene, this influx again was particularly marked. Today, the continental margin extending from Walvis Bay to Luanda is characterized by high oceanic fertility due to upwelling phenomena (Steeman-Nielsen and Jensen, 1957; Calvert and Price, 1971; Bornhold, 1973). During the Tertiary, this margin was also characterized by intermittent periods of higher oceanic fertility, particularly obvious in the upper Miocene and the Pliocene sequences. The first siliceous microfossils appear in the Eocene when the Benguela current probably began upwelling.

One of the most astonishing aspects of the Tertiary sedimentation along the Walvis Ridge is the deposition of Oligocene "Braarudosphaera chalk," reflecting unusual blooms of phytoplankton. This almost pure white "Braarudosphaera chalk" was restricted to the lower Oligocene and to the Walvis Ridge (and other South Atlantic ridges) and was not found either in the Cape or Angola 
basins. The first evidence of upwelling along the South African continental margin occurs during the Eocene and could reflect the establishment of the Benguela current.

\section{Subsidence of the Walvis Ridge Since the Cretaceous}

The Walvis Ridge has acted as an effective barrier between the Cape and Angola basins since the Early Cretaceous (early Aptian). As shown by the bathymetric evolution of Site 363 (Figure 7), and the neritic character (presence of calcarenites containing calcareous algal remains among well-rounded limestone sand grains) of its oldest sediments; the top of this barrier was close to 200 meters water depth during the late Aptian. Since that time the subsidence of the Walvis Ridge has not ceased. The mean subsidence of the Walvis Ridge since the Early Cretaceous is close to 2200 meters.

\section{A Tentative CCD Curve for the South Atlantic Since the Cretaceous}

It is difficult, if not impossible, to draw a complete curve for Cretaceous-Tertiary CCD fluctuations using only Leg 40 results. A tentative CCD curve (Figure 12) has been drawn on the basis of all previous South Atlantic DSDP drill sites (Figures 6-10). As previously mentioned the CCD during various geological periods was tentatively reconstructed using primarily the inferred depths of two particular facies through time-pelagic clays and marls deposited close to the lysocline level. Attention was also given to the past depths of well-preserved, calcareous ooze or chalk. Data obtained were compared with those proposed for the Tertiary by Berger and Roth (1975) and van Andel et al. (1975) and with those proposed for the Cretaceous by van Andel et al. (1977). The proposed average CCD curve (Figure 13 ) provides only a reference level, from which one may estimate by difference the CCD in other South Atlantic areas.

By reference to the present conditions (Figure 11) the CCD might have been approximately 200 meters deeper in the Cape Basin and 1000 meters deeper in the Angola Basin than in the Argentine/Brazil basins in the past, since, at least, the installation of the Antarctic bottom water circulation in the South Atlantic. It is well known that the Antarctic circulation began during the Eocene (Margolis and Kennett, 1970; Kennett, Houtz, et al., 1974; Schackleton and Kennett, 1975 a,b) and that the Antarctic bottom water circulation was definitely established in the western South Atlantic during the Oligocene (Perch-Nielsen, Supko, et al., 1975; LePichon et al., 1976). During the Neogene, the Antarctic bottom water

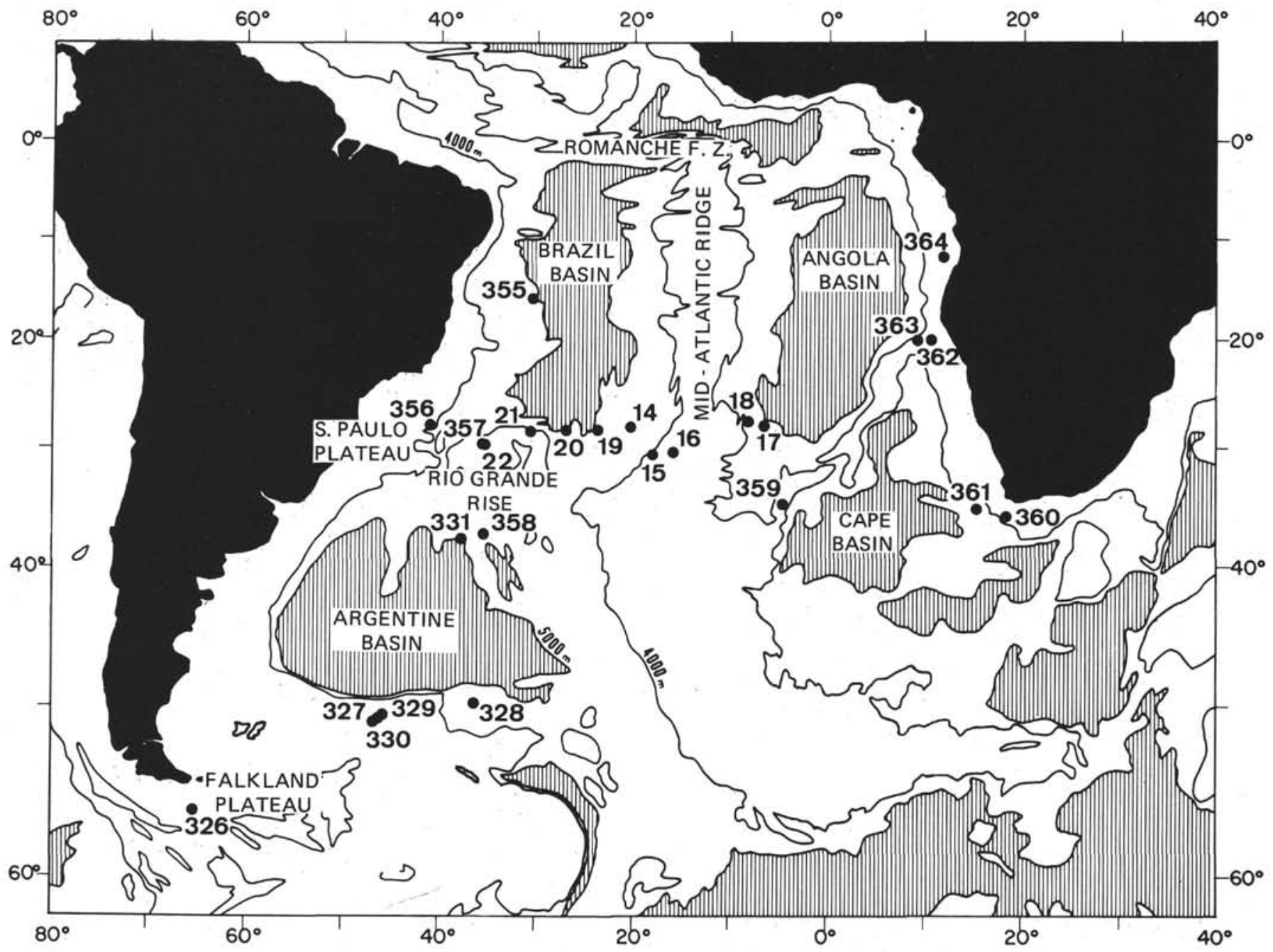

Figure 12. Topographic map of the South Atlantic Ocean. DSDP drilling sites are identified by their number. 


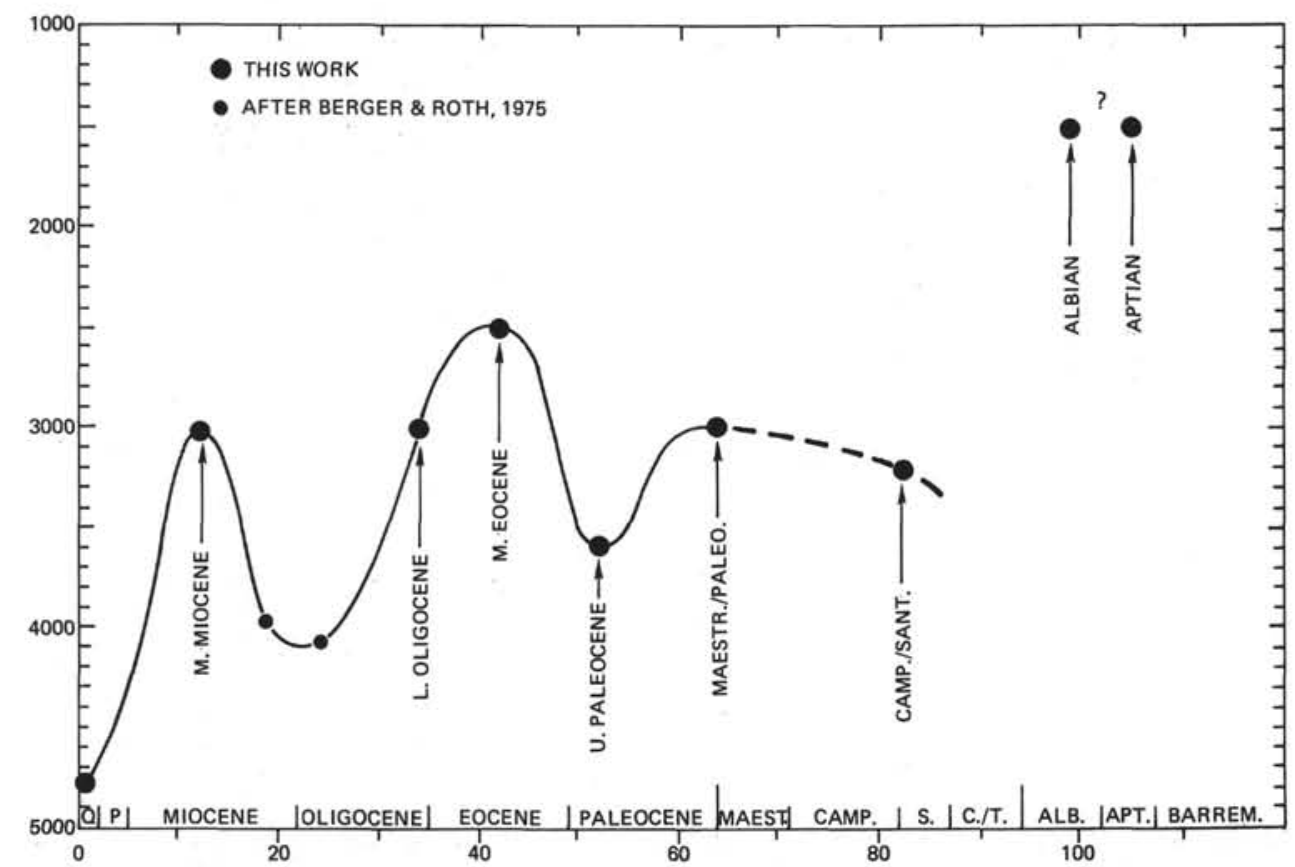

Figure 13. CCD fluctuations in the South Atlantic (average values from Argentine and Cape basins) since Aptian time. The Aptian-Albian CCD value, based on Site 361, corresponds only to periods of stagnation during which the CCD might have been fairly shallow (see text). This hypothesis disagrees, however, with that of van Andel et al. (in press) who proposes an Aptian-Albian CCD close to 3000 meters. The Santonian-Campanian CCD $(3200 \mathrm{~m})$ is based on Site 361 (Cape Basin) at which depth of heavily dissolved black shales was close to 3000 meters. I have chosen 3200 meters for the CCD to be in agreement with the value proposed by van Andel (1975). The Maestrichtian-Paleocene CCD $(3000 \mathrm{~m})$ is based on the presence of pelagic clay at Maestrichtian-Paleocene depth of 3000 meters at Site 320 in the Argentine Basin. This value is confirmed by the presence of pelagic clay at Sites 361 and 355 at the Maestrichtian/Paleocene boundary, when depths were 3200-3400 meters. The CCD values presented here for the Santonian/Campanian and the Maestrichtian/Paleocene are in agreement with those proposed by van Andel et al. (in press). The upper Paleocene CCD (3600 m) is based on the presence of pelagic clays at an upper Paleocene depth of 3600 meters in the Brazil Basin (Site 355). This is in agreement with the CCD value $(3500 \mathrm{~m})$ proposed by van Andel (1975) and close to that $(4000 \mathrm{~m})$ proposed by Ramsay (1974). The middle Eocene CCD $(2500 \mathrm{~m}$ ) is based on good data from Site 360 (Figures 1 and 6) where marls were deposited at a paleodepth of 2000 meters close to the lysocline level. This hypothesis is conformed by the occurrence of pelagic clay at a middle Eocene paleodepth of 3700 meters at Site 361 . It is also in reasonable agreement with the value $(3000 \mathrm{~m})$ proposed by Berger and Roth (1975), if we consider that the CCD is generally deeper in the Cape and Argentine basins than it is in the northern basins, for which Berger and Roth have made this estimate. The lower Oligocene $C C D(3000 \mathrm{~m})$ is based on observations made at Site 360 and is close to the $C C D(3200 \mathrm{~m})$ proposed by Berger and Roth (1975). The middle Miocene $C C D(3000 \mathrm{~m})$ is based on the presence of marls deposited at the lysocline level at a depth of 2500 meters at Site 360 (Cape Basin, Figures 1 and 6) and on the presence of pelagic clays deposited at a paleodepth of 3000 meters at Site 15 (Brazil Basin, Figure 8). This middle Miocene CCD estimate is 500 meters deeper than the one proposed by Berger and Roth (1975). From the middle Miocene to the present time, the CCD has dropped drastically to reach 4500-4800 meters in the Argentine and Brazil basins. The new CCD curve is a rough approximation of the general evolution of the CCD in the Argentine and Cape basins. The Tertiary portion of this curve is partially in disagreement (e.g., early Oligocene, middle Eocene) with that proposed by van Andel et al. (in press) for the South Atlantic. Depth proposed by van Andel et al. (in press) are approximately 1000 and 1500 meters deeper for the early Oligocene and the middle Eocene. This depth difference might be explained either by the discrepancies already mentioned about the depth-age reconstructions or by the uncertainties of the sampling procedures which might not always reflect the totality of the carbonate dissolution cycles. Furthermore, the CCD value might be different from one basin to another; the mean CCD value for the whole ocean would then be in disagreement with the CCD's of the various oceanic basins. 
was affected by numerous pulsations leading, for example, to the presence of a lower Miocene/Pliocene hiatus and to intermittent intensification of carbonate dissolution during the Pliocene/Pleistocene in the Vema Channel (Chamley, 1975; Diester-Haass, 1975; Melguen and Thiede, 1975; Melguen et al., in press). It seems reasonable to suppose that the onset and fluctuations of the Antarctic bottom current in the Cape Basin was contemporaneous with the onset and fluctuations of the current in the Argentine Basin. This hypothesis, however, cannot be applied to the Angola Basin, which received considerably less Antarctic water than the Cape, Argentine, and Brazil basins (Metcalf et al., 1964; Shannon and Van Ryswijck, 1969; Connary, 1972; Connary and Ewing, 1974). The relative isolation of the Angola Basin from the Antarctic bottom water circulation explains why there, at least today, the $\mathrm{CCD}$ is considerably deeper $(\sim 1000$ meters) than the CCD of the Cape, Argentine, or Brazil basins.

The fluctuations of the $\mathrm{CCD}$ are, at least in part, related to circulation of oceanic water masses, especially to Antarctic bottom water circulation. Therefore, the rise of the CCD in the Cape Basin during middle/late Eocene and middle/late Miocene (Figure 13) is probably related first to the establishment and then to pulsations of the deep Antarctic current.

The fluctuations of the CCD are also related to oceanic fertility (Berger, 1968; Ellis and Moore, 1973; Biscaye et al., 1976) which can give highly different $C C D$ values within the same basin. This phenomenon was also present in the past as shown by the depth difference $(\sim 2000 \mathrm{~m})$ existing between the pelagic clay facies deposited at the same period on the Falkland Plateau (Figure 10, Site 330) and in the Argentine Basin (Figure 6, Sites 328 and 358). A similar comparison can be made between the past depths of the marls deposited at the lysocline level in the Cape Basin (Figure 6, Site 360) and those deposited in the area of high productivity of the easternmost Walvis Ridge (Figure 7, Sites 362-362A). It appears that the lysocline during the middle Eocene and the lower Oligocene seems to have been more than 1000 meters shallower on the Walvis Ridge than in the Cape Basin. For this reason, the sites drilled in areas of high oceanic productivity (Falkland Plateau, easternmost Walvis Ridge) were not considered in the reconstruction of the mean South Atlantic CCD curve (Figure 13).

According to van Andel et al. (1977) the CCD was much deeper in the South Atlantic $(\sim 4000 \mathrm{~m})$ during the middle Eocene/early Oligocene because of a sharp increase in oceanic fertility. This conclusion disagrees with my observations on sediments from Sites 360 and 361 in the Cape Basin, where I see no trace of higher fertility at that time (no radiolarians or other siliceous fragments), but nevertheless infer a relatively shallow (2500-3000m) CCD (Figure 13). This might, however, again be a local phenomenon.

Finally, for the periods where the South Atlantic drill site data do not give a reliable estimate of the CCD, values previously proposed by other authors (Berger and Roth, 1975; van Andel, 1975) were used. The mean South Atlantic CCD curve was discussed in detail in a previous paper (LePichon et al., 1976).

\section{ACKNOWLEDGMENTS}

I am extremely grateful to Ms. S. Marques for her efficient, generous, and very clever help throughout this study. I also wish to thank R. Kerbat who contributed with great competence to the preparation of the material studied. I would like to thank Ms. N. Guillo, who carefully typed the manuscript, and D. Carre who drafted the figures. I am greatly thankful to X. LePichon and J. C. Sibuet who derived the paleobathymetric reconstruction proposed in this paper and that we (LePichon et al., 1976) recently presented at the IAPSO Conference in Edinburgh. Thanks are finally also expressed to H. D. Needham, W. Berger, C. Adelseck, J. Natland, and E. L. Winterer for their useful comments and generous advice.

\section{REFERENCES}

Adelseck, C.G., Jr., 1977. Recent and late Pleistocene sediments from the eastern equatorial Pacific Ocean: Sedimentation and dissolution: Thesis, University of California, San Diego.

Almeida, F. F. M. and Black. R., 1968. Geological comparison of northeastern South America and western Africa: Ann. Acad. Bras. Cienc., v. 60, p. 317-319.

Arrhenius, G. O., 1952. Sediment cores from the East Pacific: Rept. Surd. Deep-Sea Exped. (1947-1948), v. 5, p. 1-288.

Barker, P.F., Dalziel, I.W.D, et al., 1974. Southwestern Atlantic, Leg 36: Geotimes, v. 19, p. 16-18.

Berger. W. H., 1968. Planktonic foraminifera-selective solution and paleo-climatic interpretation: Deep-Sea Res., v. 15, p. $31-43$.

, 1970. Planktonic foraminifer - selective solution and the lisocline: Marine Geol., v. 8, p. 111-138.

1970. Biogenous deep-sea sediments: fractionization by deep sea circulation: Geol. Soc. Am. Bull., v. 81, p. 13851402 .

1973. Deep-sea carbonates: evidence for a coccolith lysocline: Deep-Sea Res. v. 20, p. 917-921.

1974. Deep-Sea sedimentation, In Burke and Drake (Eds.), The Geology of continental margins: Stuttgart, Springer-Verlag), p. 213-241.

in press. Sedimentation of deep-sea carbonates-maps and models of variations and fluctuations: J. Foram. Res.

Berger, W.H., Adelseck, C.G., Jr., and Mayer, L.A., 1976. Distribution of carbonate in surface sediments of the Pacific Ocean: J. Geophys. Res., v. 81 , p. 2617-2627.

Berger, W.H. and Roth, P.H., 1975. Oceanic micropaleontology - progress and prospect: Rev. Geophys. Space Phys., v. 13, p. 561-636.

Berger, W.H. and Von Rad, U., 1972. Cretaceous and cenozoic sediments from the Atlantic Ocean. In Hayes, D.E., Pimm, A.C., et al., Initial Reports of the Deep Sea Drilling Project, Volume 14: Washington (U.S. Government Printing Office), p. 787-954.

Berger, W.H. and Winterer, E.L., 1974. Plate stratigraphy and the fluctuating carbonate line. In Hsü, K.J. and Jenkyns, H., (Eds.), Pelagic sediments on land and under the sea: Spec. Publ. Internat. Assoc. Sediment., v. 1, p. 11-48.

Berggren, W. A. and Hollister, C. D., 1974. Paleogeography, paleobiogeography and the history of circulation in the Atlantic Ocean. In Hay, W. W. (Ed.), Studies in paleo-oceanography: Soc. Econ. Paleontol. Mineral. Spec. Publ. 20, p. 126-186. 
Biscaye, P. E., 1965. Mineralogy and sedimentation of recent deep-sea clay in the Atlantic ocean and adjacent seas and oceans: Geol. Soc. Am. Bull., v. 76, p. 803-832.

Biscaye, P. E. and Dasch, E. F., 1968. Source of Argentine Basin sediment, Southwestern South Atlantic Ocean: Geol. Soc. Am. (Abstracts), p. 28.

Biscaye, P.E., Kolla, V., and Turekian, K.K., 1976. Distribution of calcium carbonate in surface sediments of the Atlantic Ocean: J. Geophys. Res., v. 81 , p. $2595-2603$.

Bolli, H. M., Ryan, W. B. F., et al., 1975. Basins and margins of the eastern South Atlantic: Geotimes, v. 20, no. 6 .

Bornhold, B.D., 1973. Late Quaternary sedimentation in the eastern Angola Basin: Woods Hole Oceanographic Institution, Tech. Rept. (unpublished manuscript).

Bramlette, M.N., 1961. Pelagic sediments. In Sears, M. (Ed.), Oceanography, lectures at the international oceanographic congress. New York: (Am. Assoc. Advan. Sci. Publ. 67), p. 345366.

1965. Massive extinctions in biota at the end of Mesozoic time: Science, v. 148, p. 1696-1699.

Broecker, W.S., 1971. A kinematic model for the chemical composition of sea water: Quat. Res., v. 1, p. 188-207.

Bullard, E. C., Everett, J. E., and Smith, A. G., 1965. The fit of the continents around the Atlantic. In Blackett, P. M. S., Sullard, E. and Runcorn, S. K. (Eds.), A symposium on Continental Drift: Phil. Trans. Roy. Soc. London, Ser. A, v. 1088, p. 41-51.

Burckle, L. H. and Stanton, D., 1976. Distribution of displaced Antarctic diatoms in the Argentine Basin. In Simonsen, R. (Ed.), Symp. on Recent and Fossil Marine Diatoms, Third, Kiel, September 9-13, 1974: Royal Octavo,v. III, p. 283-292.

Calvert, S.E. and Price, N.B., 1971. Recent sediments of the south West African Shelf. In Delany, F.M. (Ed.), The geology of East Atlantic Continental Margin: Inst. Geol. Sci. Rept. 70/16, p. 173-185.

Chamley, H., 1975. Influence des courants profonds au large du Brésil sur la sédimentation argileuse récente: Ninth Congr. Intern. sédimentol., Nice, v. 8, p. 13-17.

Connary, S.D., 1972. Investigations of the Walvis Ridge and environs: $\mathrm{Ph}$. D. dissertation, Columbia University.

Connary, S.D. and Ewing, M., 1974. Penetration of Antarctic water from the Cape Basin into the Angola Basin: J. Geophys. Res., v. 79, p. 463-469.

Diester-Haass, L., 1975. Influence of Deep Oceanic currents on calcareous sands off Brazil: Ninth Congr. Intern. Sédimentol. Nice, v. 8 , p. $25-28$.

Ellis, D.B. and Moore, T.C., Jr., 1973. Calcium carbonate, opal and quartz in Holocene pelagic sediments and the calcite compensation level in the South Atlantic Ocean: J. Marine Res., v. 31 , p. $210-227$

Emery, K. O., Uchupi, E., Bowin, C., Phillips, J., and Simpson, E. S. W., 1975. Continental margin off Western Africa-Cape St. Francis (South Africa) to Walvis Ridge (South-West Africa): Am. Assoc. Petrol. Geol. Bull., v. 59, p. 3-59.

Ewing, M., 1965. The sediments of the Argentine Basin. Quat. J. Roy. Astron. Soc., v. 6, p. 10-27.

Ewing, M., Carpentier, G., Windisch, C., and Ewing, J., 1973. Sediment distribution in the oceans: Atlantic Geol. Soc. Am. Bull., v. 84, p. 71-88.

Falvey, D. A., 1974, in press. The development of continental margins in plate tectonic theory: Aust. Petrol. Expl. Assoc. J., v. 14 .

Gardner, J. V., 1975. Late Pleistocene carbonate dissolution cycles in the eastern equatorial Atlantic. Dissolution of Deep Sea carbonates. Spec. Publ. 13, Cushman Found. Foram. Res., p. 129-141.
Goldberg, E. D. and Griffin, J. J., 1964. Sedimentation rates and mineralogy in the South Atlantic: Geophys. Res., v. 69, p. 4293-4309.

Heirtzler, J. R., Dickinson, G. A., Herron, E. M., Pitman, W. C., III, and Le Pichon, X., 1968. Marine magnetic anomalies, geomagnetic field reversals, and motions of the ocean floor and continents: J. Geophys. Res., v. 73, p. 21192136.

Hollister, C. D. and Elder, R. B., 1969. Contour currents in the Weddell sea: Deep-Sea Res., v 16, p. 99-101.

Honjo, S., 1975. Dissolution of suspended coccoliths in the deepsea water column and sedimentation of coccolith ooze. In Sliter, W.W., Be, A.W.H., and Berger, W.H. (Eds.), Dissolution of deep-sea carbonates: Spec. Publ. Cushman Found. Foram. Res., no. 13, p. 114-128.

Hurley, P. M., 1968. The confirmation of continental drift: Am. Scient., v. 218 , p. $52-64$.

Hurley, P. M., De Almeida, F. F., Melcher, G. C., Cordani, U. G., Rand, J. R., Kawashita, K., Vandoros, P., Pinson, W. H., and Fairbairn, H. W., 1967. Test of continental drift by comparison of radiometric ages: Science, v. 157, p. 495-500.

Johnson, D., McDowell, S. E., and Reid, J. L., Jr., in press. Antarctic bottom water transport through the Vema Channel.

Kennett, J. P., Burns, R. E., et al., 1972. Australian-Antarctic Continental Drift, Paleocirculation changes and Oligocene deep-sea erosion: Science, v. 239, p. 51-55.

Kennett, J.P., Houtz, R.E., et al., 1974. Development of the circum-Antarctic Current: Science, v. 186, p. 144-147.

Krommelbein, K. and Wenger, R., 1966. Sur quelques analogies remarquables dans les microfaunes creétacées due Gabon et du Brésil oriental (Bahia et sergipe) In D. Reyre (Ed.), IUGS Symposium on Sedimentary basins of the African Coast, p. 193-196.

Ladd, J. W., in press. Sea-floor spreading in the South Atlantic: Geol. Soc. Am.

Ladd, J. M., Dickson, G. A., Pitman, W. C., III, 1973. The age of the South Atlantic. In Nairn and Stehli (Eds.), The Ocean basins and margins, v. 1, p. 555-571.

Langseth, K., M.G., Le Pichon, X., and Ewing, M., 1966. Crystal structure of the mid-ocean ridges, 5 . Heat flow through the Atlantic Ocean floor and convection currents: J. Geophys. Res., v. 71 , p. $5321-5355$.

Larson, R. L. and Ladd, J. W., 1973. Evidence for the opening of the south Atlantic in the Early Cretaceous: Nature, v. 246, p. 209-212.

Le Pichon, X., 1968. Sea-floor spreading and continental drift: J. Geophys. Res., v. 73, p. 3661-3697.

Le Pichon, X. and Hayes, D. H., 1971: Marginals offsets, fracture zones and the early opening of the South Atlantic: $J$. Geophys. Res., v. 76, p. 6283-6293.

Le Pichon, X., Ewing, M., and Truchan, M., 1971. Sediment transport and distribution in the Argentine basin, 2. Antarctic bottom current passage into the Brazil Basin. In Ahrens, L. H. (Ed.), Physics and chemistry of the earth: v. 8, p. 31-48.

Le Pichon, X., Francheteau, J., and Bonnin, J., 1973. Plate tectonics: Amsterdam (Elsevier).

Le Pichon, X., Melguen, M., and Sibuet, J.C., in press. A schematic model of the evolution of the South Atlantic: Paper presented at the IAPSO conference in Edinburgh (September 1976).

Le Pichon, X., Sibuet, J.C., and Francheteau, J., in press. The fit of the continents around the North Atlantic Ocean: Tectonophysics.

Leyden, R., Asmus, H., Zembruski, S., and Bryan, G., 1976. South Atlantic Diapiric structures: Am. Assoc. Geol. Petrol. Bull., v. 60 , p. $196-212$. 
Lisitzin, A. P., 1971. Distribution of siliceous microfossils in suspension and in bottom sediments. In Funnel, M. N. and Riedel, W. R. (Eds.), The Micropaleontology of Oceans, Cambridge, (Cambridge University Press), p. 173-195.

Lonardi, A. G. and Ewing, M., 1971. Sediment transport and distribution in the Argentine Basin, 4. Bathymetry of the continental margin, Argentine Basin, and other related provinces. Canyons and sources of sediments. In Ahrens, L. H. (Ed.), Physics and Chemistry of the Earth, v. 8, p. 73-121.

Maack, R., 1969. Kontinental drift und Geologie des südatlantischen Ozeans: Berlin (W. Degruyter and Co.), 164 p.

Margolis, S.V. and Kennett, J.P., 1970. Antarctic glaciation during the Tertiary recorded in sub-Antarctic deep-sea cores: Science, v. 170 , p. $1085-1087$.

Mascle, J., 1975. Géologie sous-marine du golfe de Guinée, Thèse Sciences, Université de Paris VI, 380 p.

Maxwell, A. E., et al., 1970. Initial Reports of the Deep-Sea Drilling Projects, Volume 3: Washington (U.S. Government Printing Office0.

McKenzie, D.P. and Sclater, J.G., 1969. Heat flow in the eastern Pacific and sea-floor spreading: Bull. Volcanol., v. 33, p. 101118.

Melguen, M., Bolli, H. M., et al., 1975. Facies evolution and carbonate dissolution cycles in sediments from basins and continental margins of the eastern South Atlantic since early Cretaceous: Ninth Congr. Internat. Sedimentol., Nice, v. 8, p. 43-50.

Melguen, M., Debrabant, P., Chamley, H., Maillot, H., Hoffert, M., and Courtois, C., in press. Influence des fluctuations des courants profonds sur les faciès sédimentaires du Vema channel (Atlantique sud) à la fin du Cénozoique: Marine Geol.

Melguen, M. and Thiede, J., 1974. Facies distribution and dissolution depths of surface sediment components from the Vema Channel and the Rio Grande Rise (Southwest Atlantic Ocean): Marine Geol., v. 17, p. 341-353.

1975. Influence des courants profonds au large du Brésil sur la distribution des faciès sédimentaires récents: Ninth Congr. Intern. Sédimentol., Nice, v. 8, p. 51-55.

Metcalf, W. G., Heezen, B. C., and Stalcup, M. C., 1964. The sill depth of the Mid-Atlantic Ridge in equatorial regions: Deep-Sea Res., v. 11, p. 1-10.

Murray, J. and Renard, A. F., 1891. Report on deep-sea deposits based on the specimens collected during the voyages of the H.M.S. Challenger in the years 1872 to 1976 : "Challenger Rept.", 525 p.

Nairn, A. E. M., Douglas, R. G., and Moulade, M., 1973. Causes and consequences of drift in the South Atlantic. In Tarling, D. H. and Runcorn, K. S. (Eds.), Implications of continental drift to the earth sciences: London (Acad. Press), p. 523-534.

Perch-Nielsen, K., Supko, P., et al., 1975. Leg 39 examines facies changes in south Atlantic: Geotimes, v. 20, p. 26-28.

Pratje, O., 1939. Sediments of South Atlantic: Am. Assoc. Petrol. Geol. Bull., v. 23, p. 1666-1672.

Ramsay, A. T. S., 1974. The distribution of calcium carbonates in deep-sea sediments. In Hay, W. W., (Ed.), Studies in Paleooceanography: Soc. Econ. Paleontol. Mineral., Spec. Publ. p. 58-76.

Reyment, R. A. and Tai, E. A., 1972. Biostratigraphical dating of the early history of the South Atlantic Ocean: Phil. Trans. Roy. Soc. London, v. 264, p. 55-95.

Ryan, W. B. F. and Cita, M. B., 1977: Ignorance concerning episodes of ocean-wide stagnation: Marine Geol., v. 23, p. 197-215.

Saito, T. and Percival, S. F., 1970. Mid-Atlantic Ridge sequence paleontology. In Maxwell, A. E. et al., Initial Reports of the Deep-Sea Drilling Project, Volume 3: Washington (U.S. Government Printing Office), p. 444-445.
Schackleton, N. J. and Kennett, J. P., 1975a. Paleotemperature history of the Cenozoic and the initiation of Antarctic glaciation: oxygen and carbon isotope analyses in DSDP Sites 277, 279 and 281. In Kennett, J. P., Houtz, R. E., et al., Initial Reports of the Deep-Sea Drilling Project, Volume 29: Washington (U.S. Government Printing Office), p. 743-755.

1975b. Late Cenozoic oxygen and carbon isotopic changes at DSDP Site 284. Implications for glacial history of the northern hemisphere and Antarctica. In Kennett, J. P., Houtz, R. E., et al., Initial Reports of the Deep-Sea Drilling Project, Volume 29: Washington (U.S. Government Printing Office), p. 801-807.

Schneidermann, N., 1973. Deposition of coccoliths in the compensation zone of the Atlantic Ocean. In Smith, L. A. and Hardenbol, J. (Eds.), Proc. Symp. Calcareous Nannofossils, Gulf Coast Sec., Soc. Econ. Paleontol. Mineral., Houston, Texas, p. $140-151$.

Schrader, H. J., 1971a. Selektive Auflösung planktischer Diatomeen im Seegebiet zwischen $15-43^{\circ}$ nördlicher Breite und 8-30 westlicher Länge: Second Plankt. Conf. Proc., Roma, 1970, Edizioni Tecnoscienza, p. 1139.

1971b. Ursache und Ergebnis der Auflösung von Kieselskeletten in den oberen Sedimentbereichen am Beispiel zweier Kern - profile vor Marokko und Portugal: Second Plankt. Conf. Proc., Roma, 1970, Edizioni Tecnoscienza, p. 1149.

Sclater, J. G., Anderson, R. N., and Bell, M. L., 1971. Elevation of ridges and evolution of the central eastern Pacific: J. Geophys. Res., 76, p. 7888-7915.

Sclater, J. G. and Francheteau, J., 1970. The implications of terrestrial heat-flow observations on current tectonic and geochemical models of the crust and upper mantle of the earth: Geophys. J., v. 20 , p. $509-542$.

Sclater, J. and McKenzie, D. P., 1973. Paleobathymetry of the South Atlantic: Geol. Soc. Am. Bull., v. 84, p. 3203-3215.

Seibold, E., 1970. Nebenmeere im humiden und ariden Klimabereich: Geol. Rundschau, v. 60, p. 73-105.

Shannon, L. V. and Van Rijswijck, M., 1969. Physical Oceanography of the Walvis Ridge region-Invest: Rept. Div. Sea Fisheries South Africa, no. 70.

Sheldon, R. P., 1964. Paleolatitude and paleogeographic distribution of phosphorite: U.S. Geol. Survey, Prof. Paper, 501-C, p. 106.

Sibuet, J. C. and Mascle, J., in preparation. South Atlantic equatorial fracture zones and plate kinematics.

Siesser, W. G., Scrutton, R. A., and Simpson, E. S. W., 1974. Atlantic and Indian ocean Margins of Southern Africa. In Burk, C. A. and Drake, C. L., (Eds.), The geology of continental margins. New York, (Springer-Verlag), p. 641-654.

Sleep, N. H., 1969. Sensitivity of heat-flow and gravity to the mechanism of sea-floor spreading: J. Geophys. Res., v. 74, p. $542-549$.

Steeman Nielsen, E. and Jensen, A. E., 1957. Primary oceanic production: Galathea Rephes, v. 1, p. 47-136.

Stoneley, R., 1966. The Niger delta region in the light of the continental drift: Geol. Mag., v. 103, p. 385-397.

Takahashi, T., 1975. Carbonate chemistry of seawater and the calcite compensation depth in the oceans. In Dissolution of Deep-Sea Carbonates, edit. by W. Sliter, A. W. H. B9e and W. Berger, Spec. Public., 13, p. 11-26, Cushman Foundation for Foraminiferal Research, Washington, D.C.

Tappan, H., 1968. Primary production, isotopes, extinctions and the atmosphere: Paleogeogr. Paleoclimatol. Paleoecol., v. 4, p. $187-210$.

Tarling, D. H., and Mitchell, J. G., 1976. Revised Cenozoic polarity time scale: Geology, p. 133-136.

Terry, R. D. and Chillinger, G. V., 1955. Charts for estimating percentage composition of rocks and sediments: J. Sediment. Petrol., v. 25, p. 229-234. 
Thiede, J. and Van Andel, T. H., 1977. The paleoenvironment of Anaerobic sediments in the late Mesozoic South Atlantic Ocean: Earth Planet. Sci. Lett., v. 33, p. 301-309.

Thiede, J., Pastouret, L., and Melguen, M., 1974. Sedimentation profonde au large du delta du Niger (golfe de Guinée): C. R. Acad. Sci. Paris, v. 278, p. 987-990.

Thierstein, H. R., 1976. Mesozoic calcareous nannoplankton biostratigraphy of marine sediments. Marine Micropaleontology, v. 1 , p. $325-362$.

Trehu, A., Sclater, J., and Nabelek, J., in press. The depth and thickness of the ocean crust and its dependence upon age: Bull. Soc. Géol. France.

Turekian, K. K., 1964. The geochemistry of the Atlantic Ocean basin: Trans. N.Y. Acad. Sci., v. 26, p. 312-330.

van Andel, T. H., 1975. Mesozoic Cenozoic calcite compensation depth and the global distribution of calcareous sediments: Earth. Planet. Sci. Lett., v. 26, p. 187-194.

van Andel, T. H., Thiede, J., Sclater, J. G., and Hay, W. W., 1977. Depositional history and paleoceanography of the South Atlantic Ocean during the last 125 million years: J. of Geology, v. 85 , p. $651-698$.

Venkatarathnam, K., Be, A. W. H., and Biscaye, P. E., 1976. Calcium carbonate distribution in the surface sediments of the Indian Ocean: J. Geophys. Res., v. 81, p. 2605-2616.

Vine, F. J. and Matthews, D. H., 1963. Magnetic anomalies over oceanic ridges: Nature, 199, p. 947-949.

Watkins, N. D. and Kennett, J. P., 1971. Antarctic bottom water-a major change in velocity during the late Cenozoic between Australia and Antarctica: Science, v. 173, p. 813813.

Wegener, A., 1929. Die Entstehung der Kontinente und Ozeane: Braunschweig, West Germany (F. Vieweg and Sohn), 144 p.

Worsley, T., 1974. The Cretaceous-Tertiary boundary event in the ocean. In Hay, W. W. (Ed.), Studies in Paleoceanography; Soc. Econ. Paleontol. Min., Spec. Publ. p. 94-120.

Wüst, G., 1936. Das Bodenwasser und die Gliederung der Atlantischen Tiefsee. Dtsche. Atlant. Exped. Meteor, 1925-1927, v. 6 , p. 1-106.

APPENDIX A

Per Cent of the Sediment Coarses Fractions and the Total Sediment Carbonate Content

\begin{tabular}{lrcc}
\hline $\begin{array}{c}\text { Sample } \\
\text { (Interval in cm) }\end{array}$ & $\begin{array}{c}\text { \% Fr }>63 \\
\text { microns }\end{array}$ & $\begin{array}{c}\text { \%Fr63-250 } \\
\text { microns }\end{array}$ & $\% \mathrm{CaCO}_{3}$ \\
\hline Site 360 & & & \\
$1-1,139-141$ & 6.1 & 5.4 & 78.1 \\
$1-3,139-141$ & 10.5 & 8.8 & \\
$1-5,139-141$ & 8.7 & 7.8 & 76.0 \\
$2-1,139-141$ & 10.4 & & 80.6 \\
$2-6,138-141$ & 7.2 & & 71.9 \\
$3-1,139-141$ & 7.9 & 7.0 & 73.5 \\
$3-3,139-141$ & 9.2 & 6.7 & \\
$3-6,139-141$ & 7.6 & 6.0 & 71.5 \\
$4-2,139-141$ & 6.4 & & 71.1 \\
$4-4,130-132$ & 5.9 & & 77.7 \\
$5-1,139-141$ & 7.3 & 5.8 & 81.0 \\
$5-3,139-141$ & 7.4 & 6.6 & 81.0 \\
$5-6,139-141$ & 11.6 & 10.4 & 78.1 \\
$6-1,139-141$ & 3.9 & & 79.7 \\
$6-6,139-141$ & 3.2 & 2.9 & 77.7 \\
$7-1,138-141$ & 5.3 & 3.9 & 55.4 \\
$7-6,139-141$ & 4.5 & 3.9 & 78.9 \\
$8-1,139-141$ & 3.7 & 3.2 & 74.8 \\
$8-3,139-141$ & 4.4 & 3.2 & 81.7 \\
$9-1,139-141$ & 3.4 & 3.1 & 80.5 \\
$9-3,139-141$ & 2.7 & 2.6 & \\
$9-6,139-141$ & 2.7 & 0.7 & 82.9 \\
\hline
\end{tabular}

APPENDIX A - Continued

\begin{tabular}{|c|c|c|c|}
\hline $\begin{array}{c}\text { Sample } \\
\text { (Interval in } \mathrm{cm} \text { ) }\end{array}$ & $\begin{array}{l}\% \mathrm{Fr}>63 \\
\text { microns }\end{array}$ & $\begin{array}{l}\text { \%Fr63-250 } \\
\text { microns }\end{array}$ & $\% \mathrm{CaCO}_{3}$ \\
\hline $10-1,139-141$ & 1.1 & 1.5 & 75.6 \\
\hline $10-3,139-141$ & 2.2 & 1.9 & 76.8 \\
\hline $11-3,139-141$ & 1.7 & 1.5 & 76.4 \\
\hline $11-6,139-141$ & 3.0 & 2.8 & 84.5 \\
\hline $12-1,139-141$ & 2.0 & 1.8 & 63.4 \\
\hline $12-3,139-141$ & 5.5 & 5.1 & \\
\hline $12-5,139-141$ & 5.6 & 5.1 & 67.5 \\
\hline $13-1,139-141$ & 7.7 & 6.8 & 75.6 \\
\hline $13-3,139-141$ & 5.0 & 4.3 & \\
\hline $13-6,139-141$ & 5.4 & & 79.6 \\
\hline $14-2,139-141$ & 8.5 & 7.0 & 66.1 \\
\hline $14-5,139-141$ & 4.4 & 3.8 & 67.0 \\
\hline $15-1,139-141$ & 1.8 & 1.5 & 75.4 \\
\hline $15-2,139-141$ & 4.4 & 1.5 & 76.6 \\
\hline $16-2,139-141$ & 2.3 & 2.1 & 76.2 \\
\hline $16-4,139-141$ & 3.8 & & 73.4 \\
\hline $17-1,139-141$ & 2.4 & 2.1 & 72.6 \\
\hline $17-3,139-141$ & 1.1 & 1.1 & 65.7 \\
\hline $18-1,139-141$ & 2.5 & 2.2 & 81.4 \\
\hline $18-2,139-141$ & 2.1 & 1.6 & 67.7 \\
\hline $19-2,139-141$ & 1.4 & & 68.5 \\
\hline $19-3,126-128$ & 2.3 & 2.0 & 68.5 \\
\hline $19-4,139-141$ & 2.0 & & 75.0 \\
\hline $20-1,139-141$ & 2.2 & 1.7 & 79.8 \\
\hline $20-3,139-141$ & 3.1 & 2.3 & \\
\hline $20-5,139-141$ & 2.9 & 2.3 & 75.8 \\
\hline $21-1,139-141$ & 2.1 & & 66.9 \\
\hline $21-3,139-141$ & 4.3 & 3.5 & \\
\hline $21-6,139-141$ & 5.6 & & 70.1 \\
\hline $22-3,139-141$ & 3.3 & 2.5 & 68.8 \\
\hline $22-5,139-141$ & 4.1 & 3.6 & \\
\hline $22-6,139-141$ & 20.8 & 17.0 & 72.8 \\
\hline $23-1,139-141$ & 11.3 & 10.0 & 77.4 \\
\hline $23-4,139-141$ & 11.6 & 9.8 & 79.1 \\
\hline $24-1,139-141$ & 8.1 & 7.2 & 90.7 \\
\hline $24-2,139-141$ & 2.5 & 2.4 & 83.2 \\
\hline $25-1,139-141$ & 1.6 & 1.5 & 87.7 \\
\hline $25-2,124-126$ & 5.4 & 5.0 & 87.7 \\
\hline $26-1,140-142$ & 16.2 & 13.3 & 87.3 \\
\hline $26-2,139-141$ & 11.4 & 10.2 & 79.5 \\
\hline $27-1,139-141$ & 8.5 & 7.8 & 74.6 \\
\hline $27-3,123-125$ & 12.6 & 10.6 & \\
\hline $27-4,139-141$ & 12.4 & 10.8 & 74.6 \\
\hline $28-1,139-141$ & 4.9 & 4.1 & 68.8 \\
\hline $28-3,139-141$ & 5.6 & 5.0 & \\
\hline $28-3,148 \mathrm{~A}$ & 8.8 & 6.9 & \\
\hline $28-3,148 \mathrm{~B}$ & 18.3 & 14.9 & \\
\hline $28-3,148 \mathrm{C}$ & 4.0 & 3.8 & 67.2 \\
\hline $28-4,58-59$ & 14.8 & 10.0 & 56.8 \\
\hline $28-4,66-67$ & 30.7 & 18.8 & \\
\hline $28-4,67-68$ & 30.1 & 18.8 & \\
\hline $29-1,139-141$ & 7.0 & 5.3 & 80.0 \\
\hline $29-3,139-141$ & 8.0 & 7.0 & \\
\hline $29-5,139-141$ & 4.3 & 3.7 & 76.0 \\
\hline $30-1,139-141$ & 6.0 & & 72.8 \\
\hline $30-3,139-141$ & 4.0 & & 80.0 \\
\hline $31-1,139-141$ & 4.3 & & 84.0 \\
\hline $31-3,138-141$ & 2.51 & & \\
\hline $31-6,139-141$ & 1.41 & 1.35 & 78.5 \\
\hline $32-1,139-141$ & 2.3 & 1.8 & 54.5 \\
\hline $32-3,139-141$ & 1.7 & 1.6 & \\
\hline $32-4,139-141$ & 5.1 & 4.5 & 62.4 \\
\hline $33-2,139-141$ & 6.7 & 4.8 & 66.5 \\
\hline $33-3,139-141$ & 9.6 & 6.7 & \\
\hline $33-3,128-130$ & 5.0 & 4.0 & \\
\hline $33-5,139-141$ & 7.8 & 6.1 & 68.6 \\
\hline $34-1,139-141$ & 4.7 & 3.5 & 76.0 \\
\hline $34-3,139-141$ & 5.2 & 3.7 & \\
\hline $34-6,139-141$ & 0.3 & 0.3 & 47.1 \\
\hline
\end{tabular}


APPENDIX A - Continued

\begin{tabular}{|c|c|c|c|}
\hline $\begin{array}{c}\text { Sample } \\
\text { (Interval in cm) }\end{array}$ & $\begin{array}{l}\% \mathrm{Fr}>63 \\
\text { microns }\end{array}$ & $\begin{array}{l}\% \text { Fr63-250 } \\
\text { microns }\end{array}$ & $\% \mathrm{CaCO}_{3}$ \\
\hline $35-1,139-141$ & 1.5 & 1.3 & 54.1 \\
\hline $35-3,139-141$ & 1.9 & 1.8 & 34.7 \\
\hline $36-1,139-141$ & 0.8 & 0.7 & 51.2 \\
\hline $36-3,139-141$ & 0.9 & & \\
\hline $36-4,139-141$ & 2.2 & 1.2 & 50.0 \\
\hline $37-1,139-141$ & 1.0 & 0.8 & 53.3 \\
\hline $37-2,139-141$ & 1.6 & 1.3 & 33.3 \\
\hline $38-1,139-141$ & 3.3 & 2.8 & 36.6 \\
\hline $39-1,139-141$ & 0.6 & 0.6 & 32.5 \\
\hline $39-2,139-141$ & 1.1 & 0.8 & \\
\hline $39-3,138-141$ & 1.6 & 1.5 & 29.8 \\
\hline $40-1,139-141$ & 0.1 & & 26.9 \\
\hline $40-2,139-141$ & 2.1 & & 33.4 \\
\hline $41-1,139-141$ & 2.8 & & 41.2 \\
\hline $41-2,139-141$ & 0.8 & 0.6 & 28.6 \\
\hline $42-1,139-141$ & 0.6 & 0.5 & 34.3 \\
\hline $42-3,128-130$ & 0.7 & 0.6 & \\
\hline $42-4,139-141$ & 2.3 & 1.7 & \\
\hline $43-1,139-141$ & 1.5 & 1.1 & 39.2 \\
\hline $43-2,139-141$ & 1.5 & & 58.9 \\
\hline $44-1,137-139$ & 3.0 & 1.7 & 48.4 \\
\hline $44-2,139-141$ & 0.8 & 0.6 & 39.5 \\
\hline $45-1,139-141$ & 1.6 & 1.2 & 48.4 \\
\hline $45-3,128-130$ & 0.7 & 0.5 & \\
\hline $45-5,139-141$ & 1.6 & 1.2 & 37.9 \\
\hline $46-1,139-141$ & 0.5 & & 20.9 \\
\hline $46-3,109-111$ & 0.6 & 0.6 & \\
\hline $46-4,139-141$ & 4.4 & & 51.6 \\
\hline $47-1,139-141$ & 1.1 & & 31.1 \\
\hline $47-2,139-141$ & 2.7 & 2.0 & 30.3 \\
\hline $48-1,139-141$ & 1.5 & 1.0 & 34.4 \\
\hline $48-3,128-130$ & 6.1 & 1.8 & \\
\hline $48-5,139-141$ & 0.7 & 0.5 & 34.4 \\
\hline $49-1,139-141$ & 6.0 & 3.0 & 77.0 \\
\hline $49-3,139-141$ & 3.6 & & 71.7 \\
\hline $50-1,139-141$ & 2.9 & 2.4 & 46.7 \\
\hline $50-2,139-141$ & 3.5 & 2.7 & 43.4 \\
\hline \multicolumn{4}{|l|}{ Site 361} \\
\hline $1-1,29-30$ & 9.8 & 7.2 & \\
\hline $1-1,139-141$ & 5.5 & & 4.1 \\
\hline $1-6,58-60$ & 4.6 & & \\
\hline $1-6,139-141$ & 6.0 & & 1.7 \\
\hline $2-2,16-18$ & 0.3 & 0.3 & 4.1 \\
\hline $2-2,64$ & 1.4 & & \\
\hline $2-2,76,5-77,5$ & 6.7 & 6.4 & \\
\hline $2-2,91-93$ & 0.5 & & \\
\hline $2-2,141-143$ & 1.4 & & \\
\hline $2-2,144-145$ & 39.0 & 38.5 & 3.3 \\
\hline $3-6,77-79$ & 0.5 & & 3.7 \\
\hline $3-6,88-90$ & 0.8 & & \\
\hline $3-6,104-105$ & 13.6 & 13.3 & \\
\hline $3-6,139-141$ & 3.9 & & 5.8 \\
\hline $4-1,90-92$ & 44.8 & & \\
\hline $4-1,102-104$ & 0.2 & & \\
\hline $4-1,110-112$ & 0.9 & & \\
\hline $4-1,139-141$ & 0.9 & & 14.04 \\
\hline $5-1,120-122$ & 0.8 & 0.7 & 22.7 \\
\hline $5-3,139-141$ & 0.9 & & \\
\hline $5-4,54-56$ & 0.4 & & \\
\hline $5-6,134-136$ & 0.3 & 0.3 & 21.5 \\
\hline $6-1,139-141$ & 0.2 & & 35.6 \\
\hline $6-2,40-42$ & 0.3 & & \\
\hline $6-2,62-63$ & 1.5 & 1.3 & 25.2 \\
\hline $6-2,77-78$ & 0.2 & & 25.2 \\
\hline $6-2,142-144$ & 0.3 & & \\
\hline $6-3,115-117$ & 0.8 & 0.8 & 11.4 \\
\hline $7-1,138-140$ & 0.7 & 0.6 & 54.1 \\
\hline
\end{tabular}

APPENDIX A - Continued

\begin{tabular}{|c|c|c|c|}
\hline $\begin{array}{c}\text { Sample } \\
\text { (Interval in } \mathrm{cm} \text { ) }\end{array}$ & $\begin{array}{l}\% \mathrm{Fr}>63 \\
\text { microns }\end{array}$ & $\begin{array}{l}\text { \%Fr63-250 } \\
\text { microns }\end{array}$ & $\% \mathrm{CaCO}_{3}$ \\
\hline $8-0,5-6$ & 0.2 & & 16.5 \\
\hline $8-0,11-12$ & 0.7 & & 67.8 \\
\hline $8-0,15-16$ & 0.1 & & \\
\hline $8-0,25-27$ & 0.7 & & 68.6 \\
\hline $8-0,36-37$ & 1.0 & & \\
\hline $8-1,112-114$ & 0.1 & & 69.1 \\
\hline $8-6,97-100$ & 0.1 & & \\
\hline $8-6,139-141$ & 0.2 & & 82.9 \\
\hline $9-2,63-66$ & 0.2 & & 74.6 \\
\hline $9-2,138-140$ & 0.4 & & \\
\hline $9-3,111-113$ & 0.6 & & \\
\hline $9-3,139-141$ & 3.1 & 3.0 & \\
\hline $9-6,139-141$ & 0.4 & 0.3 & 4.9 \\
\hline $10-2,30-32$ & 0.2 & & \\
\hline $10-2,129-130$ & 25.2 & 22.8 & \\
\hline $10-2,130-135$ & 5.4 & 5.1 & \\
\hline $10-3,139-141$ & 0.2 & & \\
\hline $10-6,109-111$ & $<0.1$ & & 3.2 \\
\hline $11-1,139-141$ & 0.1 & & 3.2 \\
\hline $11-3,139-141$ & $<0.1$ & & \\
\hline $11-6,109-111$ & $<0.1$ & $<0.1$ & 3.2 \\
\hline $12-1,139-141$ & 0.2 & & 4.1 \\
\hline $12-3,139-141$ & 0.5 & & \\
\hline $12-5,140-142$ & 0.8 & 0.8 & \\
\hline $13-1,48-50$ & 2.7 & 1.1 & 4.9 \\
\hline $13-1,112-115$ & 49.1 & 45.8 & 2.8 \\
\hline $14-1,109-111$ & 0.7 & & 4.9 \\
\hline $14-2,121-123$ & 0.1 & & \\
\hline $14-2,125-127$ & 1.4 & 1.4 & 3.6 \\
\hline $14-2,132-134$ & 13.7 & 13.4 & \\
\hline $14-2,139-140$ & 19.6 & 19.6 & 3.9 \\
\hline $14-2,140-142$ & 1.3 & & 3.1 \\
\hline $15-1,142-144$ & 33.4 & 22.2 & 4.7 \\
\hline $15-2,26-28$ & 0.3 & & 3.9 \\
\hline $15-2,38-41$ & 3.4 & 3.4 & 3.1 \\
\hline $15-2,53-55$ & 11.7 & 11.7 & \\
\hline $15-2,66-68$ & 58.8 & 54.0 & 3.1 \\
\hline $15-2,70-73$ & 46.7 & 45.7 & \\
\hline $15-2,82-84$ & 77.6 & 72.0 & 3.9 \\
\hline $15-2,94-97$ & 0.2 & & 2.7 \\
\hline $16-1,121-123$ & 0.2 & 0.2 & 3.1 \\
\hline $16-1,139-141$ & 1.6 & & 3.1 \\
\hline $16-1,13-16$ & & & 40.15 \\
\hline $17-1,146-148$ & $<0.1$ & & 3.1 \\
\hline $17-2,64-66$ & 0.2 & & 3.7 \\
\hline $17-2,103-105$ & 20.2 & 4.0 & 8.6 \\
\hline $17-2,124-126$ & $<0.1$ & & 3.1 \\
\hline $18-2,145-147$ & 0.1 & 0.1 & 3.11 \\
\hline $19-2,137-139$ & 0.5 & & 2.7 \\
\hline $19-4,99-101$ & $<0.1$ & & 3.8 \\
\hline $19-4,146-148$ & 0.1 & & 3.5 \\
\hline $20-1,111-113$ & 5.8 & & 35.1 \\
\hline $20-2,38-40$ & 0.2 & & 3.1 \\
\hline $20-3,112-115$ & $<0.1$ & & 3.1 \\
\hline $20-3,123-125$ & 0.2 & & 3.5 \\
\hline $20-3,125-127$ & 0.7 & & 3.1 \\
\hline $20-4,101-103$ & 0.1 & & 3.1 \\
\hline $21-2,139-141$ & 0.1 & & \\
\hline $21-3,103-105$ & 0.1 & & \\
\hline $21-4,65-67$ & 6.5 & & 3.1 \\
\hline $21-4,67-69$ & $<0.1$ & & 3.1 \\
\hline $22-1,18-20$ & $<0.1$ & & 3.1 \\
\hline $22-1,20-22$ & 0.6 & 0.6 & 3.1 \\
\hline $22-1,25-27$ & 5.5 & & 3.1 \\
\hline $22-1,135-137$ & 0.1 & & 3.9 \\
\hline $22-1,143-146$ & 2.9 & 2.8 & 3.1 \\
\hline $22-1,146-148$ & 1.5 & & 3.1 \\
\hline $22-2,139-141$ & $<0.1$ & & \\
\hline
\end{tabular}


APPENDIX A - Continued

\begin{tabular}{|c|c|c|c|}
\hline $\begin{array}{c}\text { Sample } \\
\text { (Interval in } \mathrm{cm} \text { ) }\end{array}$ & $\begin{array}{l}\% \mathrm{Fr}>63 \\
\text { microns }\end{array}$ & $\begin{array}{c}\% \text { Fr63-250 } \\
\text { microns }\end{array}$ & $\% \mathrm{CaCO}_{3}$ \\
\hline $22-3,34-41$ & 1.8 & & \\
\hline $22-4,1-3$ & 1.4 & & \\
\hline $\begin{array}{l}22-4,7-9 \\
23-2,140-143\end{array}$ & 0.5 & & 3.2 \\
\hline $23-3,102-104$ & $<0.1$ & & 3.1 \\
\hline $23-3,104-107$ & 0.1 & & \\
\hline $23-3,104-107$ & 0.1 & & \\
\hline $23-3,107-109$ & 0.3 & & \\
\hline $23-4,89-91$ & & & 2.8 \\
\hline $23-4,91-93$ & 0.2 & 0.2 & \\
\hline $23-4,93-95$ & $<0.1$ & & \\
\hline $23-4,95-97$ & 0.2 & 0.1 & \\
\hline $24-1,67-69$ & 0.1 & & \\
\hline $24-2,77-79$ & $<0.1$ & & \\
\hline $24-2,140-141$ & 0.1 & & 3.2 \\
\hline $24-2,142-145$ & $<0.1$ & & \\
\hline $24-3,134-136$ & 0.1 & & 3.2 \\
\hline $24-3,134-136$ & 0.1 & & 3.2 \\
\hline $24-4,86-88$ & $<0.1$ & & 3.6 \\
\hline $25-1,97-99$ & 0.1 & & \\
\hline $25-2,121-123$ & 0.2 & & 2.8 \\
\hline $25-4,138-140$ & & & 3.2 \\
\hline $26-2,139-141$ & 0.1 & & 4.0 \\
\hline $26-6,139-141$ & 5.1 & & 29.6 \\
\hline $27-2,107-109$ & & & 2.8 \\
\hline $27-2,113-115$ & & & 2.8 \\
\hline $28-2,15-17$ & & & 2.4 \\
\hline $28-3,98-99$ & 0.1 & & \\
\hline $28-6,49-51$ & & & 4.5 \\
\hline $28-6,51-52$ & 0.1 & & \\
\hline $29-2,132-134$ & 8.0 & 7.5 & \\
\hline $29-3,149-151$ & 49.9 & 27.2 & \\
\hline $29-4,91-94$ & 1.0 & 0.7 & 2.8 \\
\hline $29-4,96-98$ & 5.4 & & \\
\hline $29-4,99-100$ & 6.4 & 6.2 & 2.4 \\
\hline $29-5,71-72$ & 12.8 & & \\
\hline $29-5,129-131$ & 61.0 & & 2.4 \\
\hline $30-2,50-52$ & 13.8 & 12.6 & \\
\hline $30-2,52-54$ & 10.6 & & 2.4 \\
\hline $30-2,56-57$ & 2.9 & & \\
\hline $30-2,57-59$ & & & 2.4 \\
\hline $30-2,59-61$ & 19.6 & 15.1 & \\
\hline $31-3,64-66$ & 40.2 & 25.2 & \\
\hline $31-3,67-69$ & & & 13.3 \\
\hline $31-3,69-71$ & & & 11.3 \\
\hline $31-3,71-73$ & & & 10.4 \\
\hline $31-3,74-76$ & 11.3 & 7.9 & 7.2 \\
\hline $31-3,76-78$ & & & 5.6 \\
\hline $32-1,21-22$ & 35.7 & 24.6 & 2.4 \\
\hline $32-1,24-25$ & & & 5.6 \\
\hline $32-3,119-121$ & 44.9 & 31.3 & 4.0 \\
\hline $32-6,138-141$ & 1.6 & 1.5 & \\
\hline $33-3,75-76$ & 6.6 & 3.1 & 73.3 \\
\hline $33-3,76-77$ & 20.5 & 13.3 & 4.0 \\
\hline $34-3,27-29$ & & & 4.43 \\
\hline $35-1,127-128$ & & & 85.48 \\
\hline $36-1,141-142$ & 4.2 & 3.2 & 4 \\
\hline $36-1,145-147$ & 13.5 & & \\
\hline $36-1,147-149$ & 9.0 & & \\
\hline $36-3,115-116$ & 71.5 & 41.5 & 2.4 \\
\hline $38-1,90-92$ & 0.1 & 3.1 & 2.8 \\
\hline $38-1,94-96$ & 10.4 & 8.8 & \\
\hline $38-1,96-98$ & 21.4 & 19.3 & 2.4 \\
\hline $40-3,107-109$ & 44.1 & 27.0 & 2.4 \\
\hline $40-3,120-122$ & 63.1 & 31.2 & 2.4 \\
\hline $41-2,18-20$ & 72.5 & 26.9 & 2.0 \\
\hline $41-2,30-32$ & 13.4 & & 3.2 \\
\hline $41-2,36-38$ & 11.4 & 11.2 & 2.4 \\
\hline $43-3,46-48$ & & & 8.5 \\
\hline
\end{tabular}

APPENDIX A - Continued

\begin{tabular}{lccc}
\hline $\begin{array}{c}\text { Sample } \\
\text { (Interval in cm) }\end{array}$ & $\begin{array}{c}\% \mathrm{Fr}>63 \\
\text { microns }\end{array}$ & $\begin{array}{c}\% \mathrm{Fr63-250} \\
\text { microns }\end{array}$ & $\% \mathrm{CaCO}_{3}$ \\
\hline $43-3,65-67$ & 6.5 & 5.5 & \\
$43-3,69-70$ (a) & & & 23.2 \\
$43-3,69-70(\mathrm{~b})$ & & & 17.6 \\
$43-4,22-23$ & 0.5 & & \\
$43-4,24-26$ & 10.2 & & 4.0 \\
$43-4,26.5-27$ & 3.6 & & 2.4 \\
$43-4,27-28$ & 5.6 & & \\
$43-4,29-30$ & 7.9 & 7.5 & 3.2 \\
$44-1,127-128$ & & & 39.3 \\
$44-3,40-41$ & 22.8 & 20.4 & 2.4 \\
$44-3,51-52.5$ & 14.9 & & 2.8 \\
$45-1,131-138$ & 18.9 & 16.4 & \\
$45-2,26-28$ & 15.5 & 14.4 & 2.4 \\
$45-2,28-30$ & 55.9 & 32.5 & \\
$45-2,34-36$ & 17.1 & 14.5 & 3.2 \\
$45-3,92-94$ & 8.2 & & \\
$45-4,31-33$ & 3.3 & 2.3 & \\
$47-1,31-33$ & 61.9 & 30.9 & 2.8 \\
$47-1,138-140$ & 1.0 & 0.8 & 2.0 \\
$47-4,132-134$ & 18.5 & & \\
$48-2,138-140$ & 0.6 & 0.5 & 4.0 \\
$48-2,142-144$ & 53.1 & 32.5 & 8.8 \\
& & &
\end{tabular}

\section{Site 362}

$1-1,139-141$

$1-3,139-141$

$1-4,124-126$

$1-6,134-141$

2-1, 139-141

$2-3,139-141$

$2-6,139-141$

3-1, 139-141

$3-5,139-141$

4-1, 139-141

$4-2,139-141$

4-6, 139-141

$5-1,139-141$

$5-3,139-141$

5-4, 109-111

$5-6,139-141$

6-1, 139-141

6-3, 139-141

$6-5,139-141$

$6-6,139-141$

$7-1,139-141$

$7-2,139-141$

$7-3,139-141$

$7-4,139-141$

$7-6,139-141$

8-1, 139-141

$8-4,139-141$

8-6, 139-141

9-2, 139-141

9-5, 109-111

$10-1,139-141$

$10-4,139-141$

$10-5,139-141$

$10-6,139-141$

$11-1,139-141$

$11-3,139-141$

$11-4,139-141$

$11-6,139-141$

$12-1,139-141$

$12-4,139-141$

$12-5,139-141$

$12-6,139-141$

$13-1,139-141$

$13-3,139-141$

13-5, 129-131

\begin{tabular}{|c|c|c|}
\hline 40.8 & 32.8 & 68.6 \\
\hline 2.8 & 2.6 & 50.4 \\
\hline 3.0 & 2.7 & 48.8 \\
\hline 1.7 & 1.4 & \\
\hline 1.1 & & 48.0 \\
\hline 2.6 & 2.4 & 24.6 \\
\hline 2.1 & 1.4 & 24.6 \\
\hline 2.2 & 1.8 & 45.6 \\
\hline 1.5 & & \\
\hline 1.0 & & 30.9 \\
\hline 1.0 & 0.7 & \\
\hline 0.5 & 0.4 & \\
\hline 1.3 & 1.3 & 39.3 \\
\hline 1.3 & & \\
\hline 1.2 & 0.4 & 18.4 \\
\hline 0.8 & & 33.6 \\
\hline 0.3 & 0.3 & 46.4 \\
\hline 0.6 & & \\
\hline 0.6 & & 57.4 \\
\hline 0.6 & 0.4 & 56.2 \\
\hline 0.3 & & 34.4 \\
\hline 0.2 & & 38.1 \\
\hline 0.4 & & 44.6 \\
\hline 0.9 & 0.7 & 49.2 \\
\hline 0.2 & & \\
\hline 0.5 & 0.4 & 36.9 \\
\hline 1.8 & 1.6 & \\
\hline 0.7 & 0.5 & 43.8 \\
\hline 0.3 & & \\
\hline 1.1 & & \\
\hline 0.3 & 0.2 & 48.4 \\
\hline 0.8 & 0.6 & \\
\hline 0.7 & 0.5 & \\
\hline 0.5 & 0.4 & 43.4 \\
\hline 0.5 & 0.3 & 55.0 \\
\hline 0.3 & & 41.0 \\
\hline 0.5 & 0.3 & 31.8 \\
\hline 1.5 & 1.2 & \\
\hline 0.2 & 0.2 & 42.6 \\
\hline 1.2 & & 57.4 \\
\hline 0.2 & 0.2 & 50.0 \\
\hline$<0.1$ & & 47.3 \\
\hline 0.8 & 0.5 & 48.0 \\
\hline 0.6 & & 43.4 \\
\hline 0.1 & & 28.9 \\
\hline
\end{tabular}


APPENDIX A - Continued

\begin{tabular}{|c|c|c|c|}
\hline $\begin{array}{c}\text { Sample } \\
\text { (Interval in } \mathrm{cm} \text { ) }\end{array}$ & $\begin{array}{l}\% \mathrm{Fr}>63 \\
\text { microns }\end{array}$ & $\begin{array}{l}\text { \%Fr63-250 } \\
\text { microns }\end{array}$ & $\% \mathrm{CaCO}_{3}$ \\
\hline $13-6,139-141$ & 1.4 & 1.1 & 47.1 \\
\hline $\begin{array}{l}14-1,139-141 \\
14-3,139-141\end{array}$ & 0.3 & & 43.4 \\
\hline $\begin{array}{l}14-3,139-141 \\
14-6,139-141\end{array}$ & 1.3 & 1.1 & 58.2 \\
\hline $15-1,139-141$ & 0.1 & & 52.9 \\
\hline $15-3,139-141$ & 0.3 & 0.3 & 46.3 \\
\hline $15-4,139-141$ & 0.6 & 0.5 & 49.6 \\
\hline $16-1,139-141$ & 0.2 & & 25.2 \\
\hline $16-2,139-140$ & 0.6 & 0.4 & 59.4 \\
\hline $16-6,134-141$ & 0.7 & & 62.8 \\
\hline $17-1,139-141$ & 2.8 & 1.4 & 69.7 \\
\hline $17-3,139-141$ & 3.9 & 3.2 & \\
\hline $17-6,139-141$ & 3.7 & 3.2 & 59.0 \\
\hline $18-1,139-141$ & 2.7 & 2.2 & 48.3 \\
\hline $18-4,139-141$ & 1.3 & & \\
\hline $18-6,139-141$ & 1.4 & & 51.6 \\
\hline $19-1,139-141$ & 0.7 & 0.6 & 46.6 \\
\hline $19-3,139-141$ & 2.0 & & 57.8 \\
\hline $19-6,139-141$ & 0.2 & & 40.1 \\
\hline $20-1,139-141$ & 5.9 & 5.2 & 69.6 \\
\hline $20-3,139-140$ & 4.2 & 3.8 & \\
\hline $20-4,139-141$ & 4.0 & 3.6 & 74.8 \\
\hline $20-5,139-141$ & 4.9 & 4.6 & \\
\hline $20-6,139-141$ & 4.4 & 4.0 & 73.2 \\
\hline $21-1,139-141$ & 0.1 & 4.5 & 80.5 \\
\hline $21-2,139-141$ & 2.5 & & \\
\hline $21-5,139-141$ & 2.0 & & 71.9 \\
\hline $21-6,139-141$ & 3.3 & 1.6 & 67.9 \\
\hline $22-2,139-141$ & 1.6 & 1.3 & 66.6 \\
\hline $22-4,139-141$ & 2.1 & & \\
\hline $23-1,139-140$ & 0.8 & 0.6 & 74.0 \\
\hline $23-2,139-141$ & 2.0 & & 82.5 \\
\hline $23-5,109-111$ & 1.4 & & \\
\hline $23-6,139-141$ & 1.1 & 0.7 & 73.1 \\
\hline $24-1,139-141$ & 1.2 & 0.8 & 77.2 \\
\hline $24-3,139-141$ & 1.8 & & \\
\hline $24-6,139-141$ & 1.8 & 1.5 & 76.4 \\
\hline $25-2,139-141$ & 0.6 & 0.5 & 73.1 \\
\hline $25-3,139-141$ & 0.7 & 0.6 & \\
\hline $25-6,139-141$ & 0.9 & 0.7 & 65.8 \\
\hline $26-1,139-141$ & 0.9 & 0.7 & 56.9 \\
\hline $26-3,139-141$ & 1.0 & & \\
\hline $26-4,139-141$ & 0.5 & 0.2 & 27.3 \\
\hline $26-6,139-141$ & 1.3 & & 48.8 \\
\hline $27-1,139-141$ & 1.3 & 0.9 & 62.0 \\
\hline $27-3,139-141$ & 0.7 & & \\
\hline $27-5,91-93$ & 1.3 & 0.7 & \\
\hline $27-6,139-141$ & 0.9 & & 59.1 \\
\hline $28-1,139-141$ & 1.1 & 0.8 & 66.9 \\
\hline $28-3,139-141$ & 1.8 & 1.5 & \\
\hline $28-4,139-141$ & 1.0 & 0.6 & 58.2 \\
\hline $28-6,139-141$ & 2.5 & 1.5 & 46.7 \\
\hline $29-2,139-141$ & 1.0 & & 62.8 \\
\hline $29-4,139-141$ & 0.6 & 0.5 & 53.3 \\
\hline $29-5,139-141$ & 0.5 & & \\
\hline $30-1,139-141$ & 0.5 & & 56.5 \\
\hline $30-4,139-141$ & 0.8 & 0.6 & 61.5 \\
\hline $31-1,139-141$ & 0.9 & & 71.3 \\
\hline $31-2,139-141$ & 0.8 & 0.7 & \\
\hline $31-3,139-141$ & 1.4 & & 77.4 \\
\hline $31-5,139-141$ & 1.2 & 1.0 & 61.4 \\
\hline $32-1,139-141$ & 1.6 & 1.5 & 51.2 \\
\hline $32-3,139-141$ & 1.0 & 0.9 & 57.4 \\
\hline $32-6,139-141$ & 1.4 & 1.3 & 51.6 \\
\hline $33-1,139-141$ & 0.8 & 0.7 & 37.7 \\
\hline $33-2,139-141$ & 1.0 & & 68.8 \\
\hline $33-3,139-141$ & 0.6 & 0.5 & 43.4 \\
\hline $33-5,139-141$ & 1.4 & & 32.8 \\
\hline $34-1,139-141$ & 0.9 & 0.7 & 58.6 \\
\hline $34-2,139-141$ & 1.2 & & 63.1 \\
\hline
\end{tabular}

APPENDIX A - Continued

\begin{tabular}{cccc}
\hline $\begin{array}{c}\text { Sample } \\
\text { (Interval in cm) }\end{array}$ & $\begin{array}{c}\text { \% Fr }>63 \\
\text { microns }\end{array}$ & $\begin{array}{c}\text { \%Fr63-250 } \\
\text { microns }\end{array}$ & $\% \mathrm{CaCO}_{3}$ \\
\hline $34-3,109-111$ & 1.0 & 0.8 & \\
$34-5,109-111$ & 1.5 & & 56.3 \\
$35-1,139-141$ & 2.5 & 2.2 & 52.6 \\
$35-2,139-141$ & 5.4 & & 69.9 \\
$35-4,139-141$ & 5.7 & & \\
$35-6,139-141$ & 4.6 & 4.2 & 55.5 \\
$36-1,139-141$ & 13.9 & 10.2 & 70.8 \\
$36-3,139-141$ & 7.8 & & 57.6 \\
$37-1,139-141$ & 19.5 & 15.0 & 66.6 \\
$37-3,139-141$ & 10.0 & 8.5 & \\
$37-4,139-141$ & 9.9 & 8.3 & 48.7 \\
$37-6,139-141$ & 13.0 & 10.8 & \\
$38-1,139-141$ & 15.4 & 13.3 & 59.5 \\
$38-3,139-141$ & 13.5 & 11.3 & 64.0 \\
$38-4,139-141$ & 10.6 & 9.9 & \\
$38-6,139-141$ & 11.5 & 10.9 & 79.3 \\
$39-2,139-141$ & 3.6 & 3.3 & 58.7 \\
$39-4,138-141$ & 1.2 & 1.0 & \\
$39-6,139-141$ & 3.2 & 3.0 & 61.1 \\
$40-1,139-141$ & 0.8 & 0.7 & 66.5 \\
$40-3,138-141$ & 1.8 & 1.6 & \\
$40-5,123-125$ & 1.2 & 1.0 & 59.5 \\
$41-1,139-141$ & 1.3 & 1.2 & 62.4 \\
$41-2,139-141$ & 2.2 & 2.0 & 53.6 \\
$41-5,148-150$ & 1.8 & 1.6 & \\
$41-6,139-141$ & 1.6 & 1.5 & 48.7
\end{tabular}

Site 362A

2-1, 139-14

2-6, 139-141

3-1, 139-141

3-6, 149-151

4-1, 141-142

4-3, 43-55

4-4, 146-148

4-5, 69-71

$4-5,148-150$

4-6, 81-83

5-1, 86-88

$5-2,54-56$

5-3, 60-62

5-5, 114-116

5-6, 107-109

$6-1,50-52$

6-6, 133-135

7-1, 127-129

7-5, 113-115

8-1, 68-70

$8-2,77-79$

8-4, 31-33

9-1, 122-124

9-2, 9-10

$10-1,59-60$

$10-2,119-12$

$11-1,142-144$

Site 363

\begin{tabular}{rrrr}
$1-1,139-141$ & 20.2 & 14.2 & 81.6 \\
$1-3,139-141$ & 16.2 & 11.3 & \\
$1-4,109-111$ & 14.8 & 12.8 & \\
$1-6,139-141$ & 36.6 & & 73.2 \\
$2-1,139-141$ & 10.1 & 9.1 & 66.4 \\
$2-3,139-141$ & 11.9 & 11.0 & \\
$2-5,139-141$ & 11.2 & 10.1 & 66.6 \\
$3-1,139-141$ & 8.0 & 6.7 & 64.8 \\
$3-4,139-141$ & 8.1 & 7.6 & \\
$3-5,139-141$ & 8.2 & 6.9 & 68.0 \\
$4-3,145-147$ & 10.3 & & 73.6 \\
$5-2,139-141$ & 5.2 & & 72.0 \\
\hline
\end{tabular}

0.4
2.1
3.2
6.9
0.8
2.1
0.6

0.4

2.1
3.2

6.9

0.8

2.1
0.6

44.2

$0.9 \quad 40.5$

$2.7 \quad 42.0$

$6.4 \quad 60.3$

$0.7 \quad 69.5$

$\begin{array}{ll}1.8 & 53.9\end{array}$

$0.5 \quad 41.2$

95.2

92.0

86.9

49.2

88.9

86.5

$\begin{array}{lll}2.4 & 1.8 & 73.8 \\ 4.8 & 3.8 & 69.5\end{array}$

$\begin{array}{lll}2.0 & 2.0 & 74.6\end{array}$

3.7

1.4

18.2

14.6

$3.2 \quad 70.2$

$\begin{array}{ll}3.0 & 75.0\end{array}$

$1.1 \quad 75.0$

74.2

89.7

99.4

75.4

84.1

88.1

81.6

3.2

6.6

73.6
72.0 
APPENDIX A - Continued

\begin{tabular}{|c|c|c|c|}
\hline $\begin{array}{c}\text { Sample } \\
\text { (Interval in cm) }\end{array}$ & $\begin{array}{l}\% \mathrm{Fr}>63 \\
\text { microns }\end{array}$ & $\begin{array}{l}\text { \%Fr63-250 } \\
\text { microns }\end{array}$ & $\% \mathrm{CaCO}_{3}$ \\
\hline $5-3,139-141$ & 7.9 & 6.6 & \\
\hline $5-4,110-112$ & 3.5 & & \\
\hline $5-5,139-141$ & 5.3 & 5.0 & 80.0 \\
\hline $6-1,137-141$ & 3.6 & & 81.6 \\
\hline $6-2,139-141$ & 10.7 & 8.9 & \\
\hline $6-3,139-141$ & 1.7 & 1.4 & 85.6 \\
\hline $6-4,139-141$ & 5.5 & & 73.6 \\
\hline $7-1,97-99$ & 0.4 & & 80.4 \\
\hline $7-1,139-141$ & $<0.1$ & & 97.6 \\
\hline $8-1,99-101$ & 2.4 & & 78.7 \\
\hline $8-2,139-141$ & 6.8 & 5.6 & 58.2 \\
\hline $9-2,139-141$ & 1.8 & 1.6 & 71.9 \\
\hline $9-3,128-130$ & 3.2 & & 83.1 \\
\hline $9-4,139-141$ & 2.2 & 2.2 & \\
\hline $10-1,139-141$ & 4.8 & 4.1 & \\
\hline $10-2,139-141$ & 4.7 & 3.7 & 83.1 \\
\hline $10-4,139-141$ & 6.6 & 5.8 & \\
\hline $10-6,139-141$ & 3.7 & 3.3 & \\
\hline $11-1,139-141$ & 11.9 & 10.3 & \\
\hline $11-3,139-141$ & 4.3 & 3.6 & \\
\hline $11-6,139-141$ & 8.2 & 7.6 & \\
\hline $12-2,139-141$ & 8.7 & 7.4 & 81.3 \\
\hline $12-4,139-141$ & 8.9 & 6.7 & \\
\hline $12-6,139-141$ & 4.9 & 3.8 & \\
\hline $13-2,139-141$ & 5.3 & 4.2 & \\
\hline $13-3,128-130$ & 7.1 & & 82.9 \\
\hline $13-5,139-141$ & 9.2 & 7.6 & \\
\hline $14-1,139-140$ & 3.8 & 3.3 & 91.0 \\
\hline $14-2,139-141$ & 3.6 & 3.4 & \\
\hline $14-4,135-137$ & 4.2 & 3.7 & \\
\hline $14-6,139-141$ & 5.4 & 4.6 & 93.2 \\
\hline $15-1,139-141$ & 2.6 & 2.2 & \\
\hline $16-1,139-141$ & 6.5 & 6.2 & 75.6 \\
\hline $16-2,139-141$ & 2.4 & 2.2 & \\
\hline $17-1,139-141$ & 7.3 & & 82.2 \\
\hline $17-2,139-141$ & 8.1 & 7.9 & 82.6 \\
\hline $18-4,129-131$ & & & \\
\hline $18-5,139-141$ & 6.2 & 5.2 & 85.82 \\
\hline $19-2,139-141$ & 3.7 & 3.3 & \\
\hline $19-3,139-141$ & 5.1 & & 83.0 \\
\hline $19-6,139-141$ & 5.8 & 4.9 & \\
\hline $20-1,139-141$ & 2.0 & 1.7 & 81.3 \\
\hline $20-2,129-130$ & 6.8 & 4.8 & \\
\hline $20-3,139-141$ & 9.0 & 5.8 & 81.1 \\
\hline $21-1,139-141$ & & & 83.0 \\
\hline $21-2,139-141$ & 0.6 & 0.5 & 74.9 \\
\hline $21-4,14-16$ & 1.3 & & \\
\hline $21-5,129-141$ & 1.6 & 1.5 & 70.6 \\
\hline $22-1,139-141$ & 0.6 & 0.5 & \\
\hline $23-2,139-141$ & 0.2 & & 44.8 \\
\hline $24-2,139-141$ & 2.3 & & 40.9 \\
\hline $25-2,139-141$ & $\therefore$ & & 71.4 \\
\hline $26-1,91-93$ & 2.3 & 2.3 & 40.6 \\
\hline $26-2,77-79$ & & & 79.2 \\
\hline $26-3,89-91$ & 2.8 & & 49.8 \\
\hline $26-4,2-4$ & 1.0 & & 28.6 \\
\hline $26-4,139-141$ & 2.1 & 2.0 & 60.1 \\
\hline $27-1,41-43$ & 1.7 & 1.7 & 47.5 \\
\hline $28-1,101-107$ & & & 72.6 \\
\hline $28-2,139-141$ & 1.0 & 1.0 & 43.5 \\
\hline $28-3,68-70$ & 3.2 & & \\
\hline $28-5,85-87$ & 4.2 & 4.0 & 63.3 \\
\hline $28-6,57-59$ & 1.8 & 1.7 & 35.5 \\
\hline $29-1,59-61$ & 15.0 & 2.7 & 73.4 \\
\hline $29-2,76-78$ & 0.8 & 0.7 & 55.6 \\
\hline $29-3,50-52$ & & & 69.3 \\
\hline $29-5,93-95$ & 3.2 & 3.2 & \\
\hline $29-6,66-68$ & & & 70.1 \\
\hline $30-1,28-30$ & 1.1 & 1.0 & \\
\hline
\end{tabular}

APPENDIX A - Continued

\begin{tabular}{|c|c|c|c|}
\hline $\begin{array}{c}\text { Sample } \\
\text { (Interval in } \mathrm{cm} \text { ) }\end{array}$ & $\begin{array}{l}\% \mathrm{Fr}>63 \\
\text { microns }\end{array}$ & $\begin{array}{l}\% \text { Fr63-250 } \\
\text { microns }\end{array}$ & $\% \mathrm{CaCO}$ \\
\hline $30-2,2-4$ & & & 58.9 \\
\hline $30-3,137-139$ & & & 70.1 \\
\hline $30-4,80-82$ & 3.1 & 3.1 & 49.8 \\
\hline $30-5,88-90$ & & & 56.6 \\
\hline $30-6,31-33$ & 6.0 & 5.8 & 57.9 \\
\hline $31-1,116-118$ & 1.4 & 1.4 & \\
\hline $31-5,121-123$ & & & 70.5 \\
\hline $31-6,71-73$ & & & 65.5 \\
\hline $32-1,117-119$ & & & 80.4 \\
\hline $32-2,24-26$ & & & 73.2 \\
\hline $33-2,40-42$ & & & 69.7 \\
\hline $33-4,77-79$ & & & 69.2 \\
\hline $33-6,109-111$ & & & 72.3 \\
\hline $34-3,28-30$ & & & 61.1 \\
\hline $35-1,79-81$ & & & 84.4 \\
\hline $35-2,24-26$ & & & 81.9 \\
\hline $36-1,80-82$ & & & 59.8 \\
\hline $36-3,111-113$ & & & 47.9 \\
\hline $37-5,78-82$ & & & 86.8 \\
\hline $37-6,83-85$ & 0.9 & & 50.8 \\
\hline $38-1,78-80$ & & & 73.8 \\
\hline $39-2,82-84$ & & & 66.9 \\
\hline
\end{tabular}

Site 364

\begin{tabular}{|c|c|c|c|}
\hline $1-2,74-76$ & 0.4 & 0.3 & $\cong 8$ \\
\hline $1-3,139-141$ & 0.4 & 0.2 & 7.9 \\
\hline $1-6,124-126$ & 2.1 & 1.2 & 5.3 \\
\hline $2-3,139-141$ & 2.3 & 1.6 & 5.7 \\
\hline $3-1,124-126$ & 2.3 & 1.6 & 34.5 \\
\hline $3-2,139-141$ & 1.3 & 1.1 & \\
\hline $3-3,100-102$ & 5.1 & 2.1 & 37.3 \\
\hline $3-6,144-146$ & 1.5 & 1.1 & 43.6 \\
\hline $4-6,139-141$ & 0.2 & 0.2 & 6.3 \\
\hline $5-2,100-102$ & 0.2 & 0.1 & \\
\hline $6-1,139-141$ & 0.3 & 0.3 & 3.9 \\
\hline $6-2,139-141$ & 32.4 & 30.2 & \\
\hline $6-6,139-141$ & 1.7 & 1.7 & 4.3 \\
\hline $8-1,139-141$ & 0.2 & 0.2 & 40.5 \\
\hline $8-5,139-141$ & 0.2 & 0.2 & \\
\hline $9-1,122-124$ & 6.2 & 5.5 & 67.4 \\
\hline $9-1,137-139$ & 5.3 & 5.0 & 78.6 \\
\hline $9-4,130-131$ & 0.6 & 0.05 & 50.8 \\
\hline $9-4,132-134$ & 2.0 & 1.8 & 57.0 \\
\hline $10-1,139-141$ & 0.2 & 0.15 & 57.8 \\
\hline $10-3,130-132$ & 4.9 & 1.8 & 66.9 \\
\hline $10-4,102-104$ & 0.3 & 0.2 & 57.4 \\
\hline $10-4,129-131$ & 4.8 & 4.6 & 75.5 \\
\hline $10-5,90-92$ & 0.2 & 0.2 & 49.0 \\
\hline $10-5,114-116$ & 0.1 & 0.1 & 12.2 \\
\hline $10-6,121-123$ & 0.4 & 0.4 & 36.6 \\
\hline $11-1,140-142$ & 0.1 & 0.1 & 65.8 \\
\hline $12-1,139-141$ & 0.2 & 0.2 & 54.5 \\
\hline $12-6,121-123$ & 0.2 & 0.2 & 55.6 \\
\hline $13-1,61-63$ & 0.3 & 0.2 & 55.3 \\
\hline $13-2,134-136$ & 0.3 & 0.3 & 54.5 \\
\hline $14-1,140-142$ & 0.3 & 0.3 & 61.8 \\
\hline $14-5,88-90$ & 0.2 & 0.2 & \\
\hline $14-6,139-141$ & 0.2 & 0.2 & 70.7 \\
\hline $15-2,96-98$ & 0.4 & 0.3 & \\
\hline $15-4,139-141$ & 0.2 & 0.2 & 62.2 \\
\hline $15-5,77-79$ & 0.02 & 0.02 & \\
\hline $17-1,113-115$ & 0.2 & 0.2 & 65.8 \\
\hline $17-1,117-119$ & 0.1 & 95.0 & \\
\hline $17-6,25-26$ & 0.3 & 92.6 & 65.5 \\
\hline $19-4,86-87$ & 1.3 & 89.5 & 38.5 \\
\hline $20-2,34-37$ & 0.2 & 76.6 & 22.1 \\
\hline $20-3,100-102$ & 0.6 & 80.5 & 6.5 \\
\hline $20-3,103-105$ & 1.6 & 88.7 & \\
\hline
\end{tabular}


APPENDIX A - Continued

\begin{tabular}{lccc}
\hline $\begin{array}{c}\text { Sample } \\
\text { (Interval in cm) }\end{array}$ & $\begin{array}{c}\text { \% Fr }>63 \\
\text { microns }\end{array}$ & $\begin{array}{c}\text { \%Fr63-250 } \\
\text { microns }\end{array}$ & \% $\mathrm{CaCO}_{3}$ \\
\hline $21-1,139-141$ & 0.7 & 85.0 & 55.7 \\
$21-2,14-15$ & 1.5 & 64.2 & 5.7 \\
$21-2,31-33$ & 0.6 & 81.2 & \\
$21-4,114-116$ & 56.6 & 35.5 & 4.8 \\
$21-6,139-141$ & 0.4 & 87.7 & 46.0 \\
$22-4,139-141$ & 6.6 & 94.6 & 67.2 \\
$23-1,139-141$ & 2.6 & 59.1 & 14.6 \\
$23-3,143-145$ & 0.6 & 55.1 & 54.2 \\
$23-4,143-145$ & 4.0 & 68.6 & 41.3 \\
$24-1,116-119$ & 1.3 & 98.3 & 3.6 \\
$24-2,53-55$ & 0.5 & 74.0 & 43.7 \\
$25-3,69-70$ & 6.8 & 35.5 & 3.2 \\
$25-4,74-76$ & 4.0 & 90.3 & 4.0 \\
$25-6,103-104$ & 7.4 & 74.5 & 36.1 \\
$26-1,136-137$ & 0.7 & 96.6 & 29.3 \\
$26-2,98-99$ & 1.6 & 98.2 & 22.5 \\
$26-4,77-78$ & 2.9 & 95.3 & 30.8 \\
$26-6,53-55$ & 4.9 & 96.0 & 34.8 \\
$27-1,138-139$ & 3.7 & 99.2 & 46.8 \\
$27-2,166-168$ & 23.1 & 84.0 & 55.9 \\
$27-3,36-38$ & 17.4 & 87.3 & 36.0 \\
$27-5,94-96$ & 4.4 & 99.9 & 51.2 \\
$28-1,51-52$ & 3.5 & 95.1 & 71.2 \\
$28-2,31-33$ & 10.9 & 98.2 & 54.8 \\
\hline
\end{tabular}

APPENDIX A - Continued

\begin{tabular}{|c|c|c|c|}
\hline $\begin{array}{c}\text { Sample } \\
\text { (Interval in } \mathrm{cm} \text { ) }\end{array}$ & $\begin{array}{c}\% \mathrm{Fr}>63 \\
\text { microns }\end{array}$ & $\begin{array}{l}\% \text { Fr63-250 } \\
\text { microns }\end{array}$ & $\% \mathrm{CaCO}_{3}$ \\
\hline $29-1,126-128$ & 3.6 & 98.8 & 32.2 \\
\hline $29-3,100-101$ & 1.8 & 96.5 & 29.8 \\
\hline $29-4,24-26$ & 5.0 & 96.0 & 43.5 \\
\hline $30-1,141-143$ & 17.3 & 99.0 & 53.2 \\
\hline $30-2,109-111$ & 7.4 & 95.2 & \\
\hline $31-1,24-26$ & 6.5 & 98.5 & 17.7 \\
\hline $31-2,123-125$ & 4.5 & 95.5 & 29.0 \\
\hline $31-3,119-121$ & 12.9 & 98.5 & 51.6 \\
\hline $32-1,39-41$ & 1.6 & 99 & 46.0 \\
\hline $32-1,143-145$ & 0.3 & 96.9 & \\
\hline $32-3,32-34$ & 0.3 & 80.0 & 25.8 \\
\hline $33-1,92-94$ & 3.8 & 95.5 & 45.9 \\
\hline $33-3,121-122$ & 5.6 & 98.3 & 43.5 \\
\hline $33-5,36-37$ & 17.5 & 97.6 & 37.1 \\
\hline $33-5,47-50$ & 14.5 & 99.0 & 50.0 \\
\hline $34-1,112-115$ & 9.5 & 97.6 & 48.8 \\
\hline $34-1,141-143$ & 4.5 & 99.2 & 23.2 \\
\hline $34-3,28-30$ & 18.15 & 94.7 & 89.5 \\
\hline $34-4,51-53$ & 23.5 & 93.3 & 58.1 \\
\hline $35-2,74-76$ & 8.9 & 98.1 & 53.6 \\
\hline $37-1,7-9$ & 11.5 & 98.5 & 48.4 \\
\hline $37-3,89-90$ & 6.8 & 89.0 & 44.8 \\
\hline $38-4,137-139$ & 6.8 & 85.1 & 38.7 \\
\hline $39-3,68-69$ & 6.2 & 87.1 & \\
\hline
\end{tabular}


APPENDIX B

\begin{tabular}{|c|c|c|c|c|c|c|c|c|c|c|c|c|c|c|c|c|c|c|c|c|c|c|}
\hline $\begin{array}{c}\text { Sample } \\
\text { (Interval in } \mathrm{cm} \text { ) }\end{array}$ & 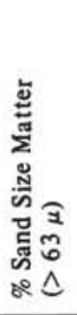 & $\begin{array}{l}\stackrel{0}{\tilde{W}} \\
\text { రू } \\
\text { sீ }\end{array}$ & 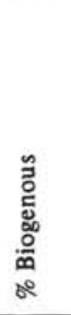 & 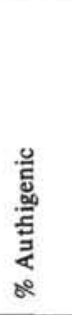 & 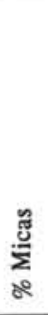 & 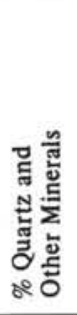 & 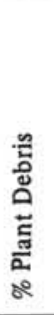 & 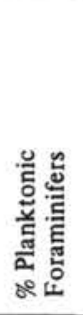 & $\begin{array}{l}\frac{0}{0} \\
\text { 웅 } \\
\text { 옹 }\end{array}$ & 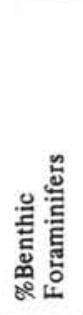 & 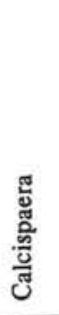 & 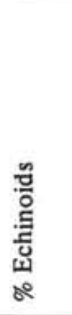 & 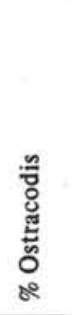 & $\begin{array}{l}\frac{5}{5} \\
\text { 竞 } \\
\text { se }\end{array}$ & 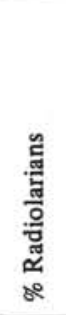 & 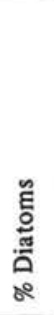 & 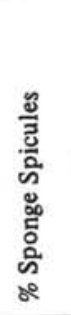 & 营 & 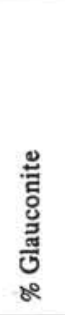 & 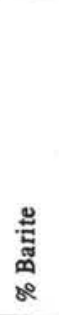 & 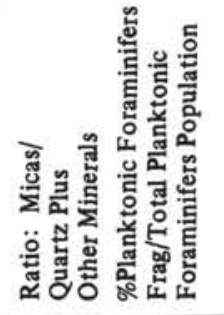 & 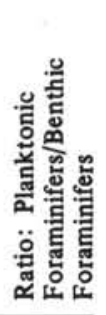 \\
\hline \multicolumn{23}{|l|}{ Site 360} \\
\hline $1-1,139-141$ & 6.1 & - & 100 & - & & & & 98 & & 1 & & 0.5 & 0.5 & & & & & & & & $\leqslant 10$ & 98 \\
\hline $1-3,139-141$ & 10.5 & - & 100 & - & & & & 99 & & 0.5 & & 0.5 & 0.5 & & & & & & & & $<10$ & 198 \\
\hline $1-5,139-141$ & 8.7 & 2 & 100 & - & & & & 99 & & 0.5 & & 1 & 1 & & & & & & & & $\leqslant 10$ & 198 \\
\hline $3-1,139-141$ & 7.9 & - & 100 & - & & & & 95 & & 1 & & 5 & & & & & 0.5 & & & & $\leqslant 20$ & \\
\hline $3-3,139-141$ & 9.2 & - & 100 & - & & & & $>90$ & & & & 3 & & 0.5 & & & 0.5 & & & & $<20$ & \\
\hline $3-6,139-141$ & 7.6 & - & 100 & - & & & & $>90$ & & 0.5 & & 3 & & 0.5 & & & & & & & $<5$ & \\
\hline $4-4,130-132$ & 5.9 & & 90 & & & & & $>75$ & & 5 & & 3 & 1 & & & & & & & & $<5$ & 16 \\
\hline $5-1,139-141$ & 7.3 & & 100 & & & & & $>90$ & & 2 & & 3 & 0.5 & 0.5 & & & & & & & 5 & 45 \\
\hline $5-3,139-141$ & 7.4 & & 95 & 5 & & & & $>90$ & & & & & 1 & 0.5 & & & & 5 & & & 5 & \\
\hline $5-6,139-141$ & 11.6 & & 100 & & & & & 95 & & 5 & & & & 0.5 & & & & & & & 20 & 19 \\
\hline $6-1,139-141$ & 3.9 & & 95 & 5 & & & & 90 & & 5 & & 1 & 1 & 0.5 & & & & 5 & & & 20 & 18 \\
\hline $7-1,139-141$ & 5.3 & & 100 & & & & & 95 & & 1 & & & & 1 & & & & 1 & & & 10 & \\
\hline $7-3,139-141$ & 6.5 & & 100 & & & & & 95 & & & & 1 & & 1 & & & & 1 & & & 10 & \\
\hline $7-6,139-141$ & 4.5 & & 100 & & & & & 98 & & 1 & & & & 1 & & & & 1 & & & 10 & \\
\hline $8-1,139-141$ & 3.7 & & 99 & 1 & & & & 90 & & 3 & & & & 0.5 & & & & 1 & & & 5 & 30 \\
\hline $8-3,139-141$ & 4.4 & & 99 & 1 & & & & $>95$ & & 1 & & & & 0.5 & & & & 1 & & & 5 & 95 \\
\hline $9-1,139-141$ & 3.4 & & 100 & & & & & 95 & & 1 & & & & 0.5 & & & & 1 & & & 10 & \\
\hline $9-3,139-141$ & 2.7 & & 100 & & & & & 95 & & 1 & & & & 1 & & & & 1 & & & 10 & \\
\hline $9-6,139-141$ & 2.7 & & 100 & & & & & 95 & & 1 & & & & 1 & & & & 1 & & & 30 & \\
\hline $10-1,139-141$ & 1.1 & & 95 & 5 & & & & 80 & & 5 & & 3 & 0.5 & 3 & & & & 5 & & & 50 & 16 \\
\hline $10-3,139-141$ & 2.2 & & 98 & 2 & & & & 90 & & 1 & & & & 0.5 & 0.5 & & 0.5 & 2 & & & 75 & 90 \\
\hline $11-3,139-141$ & 1.7 & & 95 & 5 & & & & 90 & & 2 & & & & 0.5 & & & & 5 & & & 20 & 45 \\
\hline $11-6,139-141$ & 3.0 & & 98 & & & & & 90 & & 5 & & & & 3 & tr & & & 2 & & & 30 & 18 \\
\hline $12-1,139-141$ & 2.0 & & & & & & & & & & & & & & & & & & & & $\geqslant 50$ & \\
\hline $12-3,139-141$ & 5.5 & & & & & & & & & & & & & & & & & & & & 40 & \\
\hline $12-5,-139-141$ & 5.6 & & & & & & & & & & & & & & & & & & & & 10 & \\
\hline $13-1,139-141$ & 7.7 & & & & & & & 95 & & 2 & & 0.5 & & 0.5 & & & & & & & $<2$ & 47.5 \\
\hline $14-2,139-141$ & 8.5 & & & & & & & & & & & & & & & & & & & & 20 & \\
\hline $14-5,139-141$ & 4.4 & & & & & & & & & & & & & & & & & & & & 30 & \\
\hline $15-2,139-141$ & 4.4 & & 98 & 2 & & & & 90 & & 3 & & & & 2 & & & & 2 & & & & 30 \\
\hline $16-2,139-141$ & 2.3 & & 95 & 5 & & & & 90 & & 2 & & $\operatorname{tr}$ & & 1 & & & & 5 & & & 20 & 45 \\
\hline $17-1,139-141$ & 2.4 & & 98 & 2 & & & & $>90$ & & 2 & & & & 1 & & & & 2 & & & 5 & 45 \\
\hline $17-3,139-141$ & 1.1 & & 98 & 2 & & & & 90 & & 6 & & 1 & & 2 & & & & 2 & & & $\geqslant 75$ & 16 \\
\hline $18-1,139-141$ & 2.5 & & 98 & 2 & & & & 90 & & & & & & 2 & & & & 2 & & & 75 & \\
\hline $18-2,139-141$ & 2.1 & & 98 & 2 & & & & $>90$ & & & & & & 3 & & & & 2 & & & $>75$ & \\
\hline $19-2,139-141$ & 1.4 & & 99 & 1 & & & & 90 & & 1 & & 0.5 & & 1 & & & & 1 & & & 75 & 90 \\
\hline $19-3,126-128$ & 2.3 & & 85 & 15 & & & & 80 & & i & & & & 1 & & & & 15 & & & 75 & 80 \\
\hline $19-4,139-141$ & 2.0 & & 99 & 1 & & & & $>95$ & & & & & & 3 & & & & 1 & & & 50 & \\
\hline $20-1,139-141$ & 2.2 & & 90 & 10 & & & & 90 & & 1 & & 0 & 01 & 1 & & & & & & & 75 & 90 \\
\hline $20-3,139-141$ & 3.1 & & 70 & 30 & & & & 70 & & 1 & & 1 & 1 & 1. & & & & & & & 10 & 70 \\
\hline $20-6,139-141$ & 2.9 & & 95 & 5 & & & & 90 & & 0.5 & & 1 & 0.5 & 0.5 & & & 0.5 & & & & 30 & 180 \\
\hline $21-1,139-141$ & 2.1 & 15 & 85 & 0.5 & & & & 80 & & & & & & 0.5 & & & & & & & $\begin{array}{l}80 \\
50\end{array}$ & \\
\hline
\end{tabular}

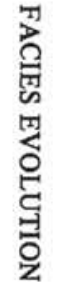


Site 360 - Continued

\begin{tabular}{|c|c|c|c|c|c|c|c|c|}
\hline $22-3,139-141$ & 3.3 & & 98 & 2 & & & $>90$ & 2 \\
\hline $22-5,139-141$ & 4.1 & & 100 & & & & $>90$ & \\
\hline $22-6,139-141$ & 20.8 & & 100 & & & & $>95$ & \\
\hline $23-1,139-141$ & 11.3 & & 100 & & & & $>95$ & 0.5 \\
\hline $23-3,128-130$ & & & 100 & & & & $>95$ & \\
\hline $23-4,139-141$ & 11.6 & & 100 & & & & $>95$ & 0.5 \\
\hline $24-1,139-141$ & 8.1 & & 100 & & & & 100 & \\
\hline $24-2,139-141$ & 2.5 & & & & & & $>95$ & 2 \\
\hline $25-1,139-141$ & 1.6 & & 100 & & & & 95 & 2 \\
\hline $25-2,139-141$ & 5.4 & & 100 & & & & 98 & 0.5 \\
\hline $26-1,140-142$ & 16.2 & & 100 & & & & 98 & \\
\hline $26-2,139-141$ & 11.4 & & 100 & & & & 98 & \\
\hline $27-1,139-141$ & 8.5 & & 100 & & & & 98 & \\
\hline $27-3,123-125$ & 12.6 & & 100 & & & & 100 & \\
\hline $27-4,139-141$ & 12.4 & & 100 & & & & 98 & 0.5 \\
\hline $28-1,139-141$ & 4.9 & & 100 & & & & $>98$ & \\
\hline $28-3,139-141$ & 5.6 & & 90 & 10 & & & 90 & 2 \\
\hline $28-3,148 \mathrm{~A}$ & 8.8 & & 100 & & & & $>98$ & \\
\hline $28-3,148 B$ & 18.3 & 10 & 90 & & & & 90 & \\
\hline $28-3,148 \mathrm{C}$ & 4.0 & 5 & 95 & & & 5 & $>90$ & 1 \\
\hline $28-4,50-54$ & 14.8 & 10 & 85 & 5 & & 10 & 85 & 2 \\
\hline $28-4,66-67$ & 30.7 & 30 & 65 & 5 & & 20 & 65 & 0.5 \\
\hline $28-4,68-69$ & 30.1 & 30 & 68 & 2 & & 20 & $>65$ & 1 \\
\hline $29-1,139-141$ & 7.0 & & 100 & & & & $>95$ & \\
\hline $29-3,139-141$ & 8.0 & & 100 & & & & 100 & \\
\hline $29-5,139-141$ & 4.3 & & 100 & & & & 99 & 0.5 \\
\hline $30-1,139-141$ & 6.0 & & 100 & & & & 100 & \\
\hline $30-3,139-141$ & 4.0 & & 100 & & & & 98 & 1 \\
\hline $31-1,139-141$ & 4.3 & & 100 & & & & 98 & 1 \\
\hline $31-3,139-141$ & 2.5 & & $\cong 100$ & 0.5 & & & 95 & \\
\hline $31-6,139-141$ & 1.4 & & 100 & & & & 98 & 1 \\
\hline $32-1,139-141$ & 2.3 & 1 & 94 & 5 & 0.5 & 0.5 & $>90$ & 1 \\
\hline $32-3,139-141$ & 1.7 & 1 & 99 & & 0.5 & 1 & $>95$ & \\
\hline $32-4,139-141$ & 5.1 & & 100 & & & & 98 & 1 \\
\hline $33-2,139-141$ & 6.7 & & 100 & & & & 98 & 1 \\
\hline $33-3,128-130$ & 5.0 & 1 & $\cong 100$ & & 1 & & 98 & 1 \\
\hline $33-3,139-141$ & 9.6 & & 100 & & & & $>98$ & 1 \\
\hline $33-5,139-141$ & 7.8 & & 100 & & & & $>98$ & 1 \\
\hline $34-1,139-141$ & 4.7 & & 100 & & & & 95 & \\
\hline $34-3,139-141$ & 4.2 & & 100 & & & & $>98$ & 1 \\
\hline $34-6,137-141$ & 0.3 & 30 & 60 & 10 & & 30 & 60 & 1 \\
\hline
\end{tabular}

0.5

$\begin{array}{llll}0.5 & & 0.5 & \\ & & 0.5 & \\ 0.5 & & & \\ 2 & 0.5 & & 0.5 \\ 2 & 1 & 0.5 & 1 \\ 0.5 & & 0.5 & 0.5 \\ & & & 0.5 \\ & 1 & 0.5 & 0.5 \\ & 0.5 & 0.5 & 0.5 \\ 0.5 & & 0.5 & 0.5 \\ & 0.5 & & 0.5 \\ 2 & & & 0.5 \\ & & 0.5 & 0.5 \\ 1 & 0.5 & 0.5 & 0.5 \\ 2 & 0.5 & & 0.5 \\ 0.5 & & & \\ 1 & & & 0.5 \\ & & & 0.5\end{array}$

0.5

$\begin{array}{ccl} & & 0.5 \\ & & 0.5 \\ & & 0.5 \\ & & 0.5 \\ & 0.5 & 1 \\ 0.5 & 0.5 & 2 \\ 0.5 & & 0.5 \\ & & 0.5 \\ & & 0.5 \\ & & 0.5 \\ & 0.5 & 1 \\ & & 1 \\ & & 5 \\ & & \\ & & \text { tr } \\ & & 1\end{array}$

2

45

190

190

47.5

47.5
196

196

${ }^{0.5}$

45

90

42.5

42.5

130
65

198

98
98

0.5

5

1
0.5

10

90
90
47.5
47.5
96

6

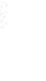




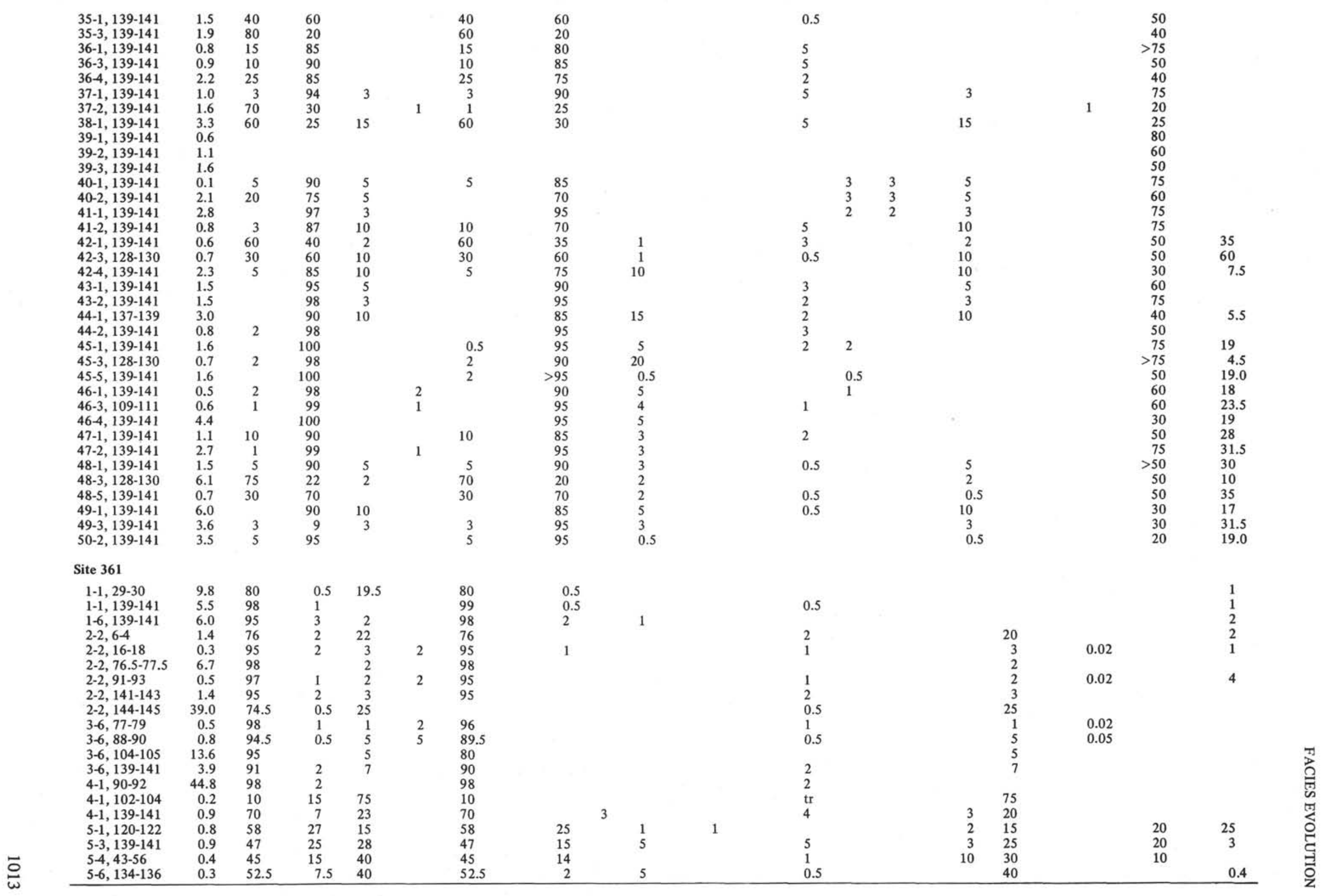




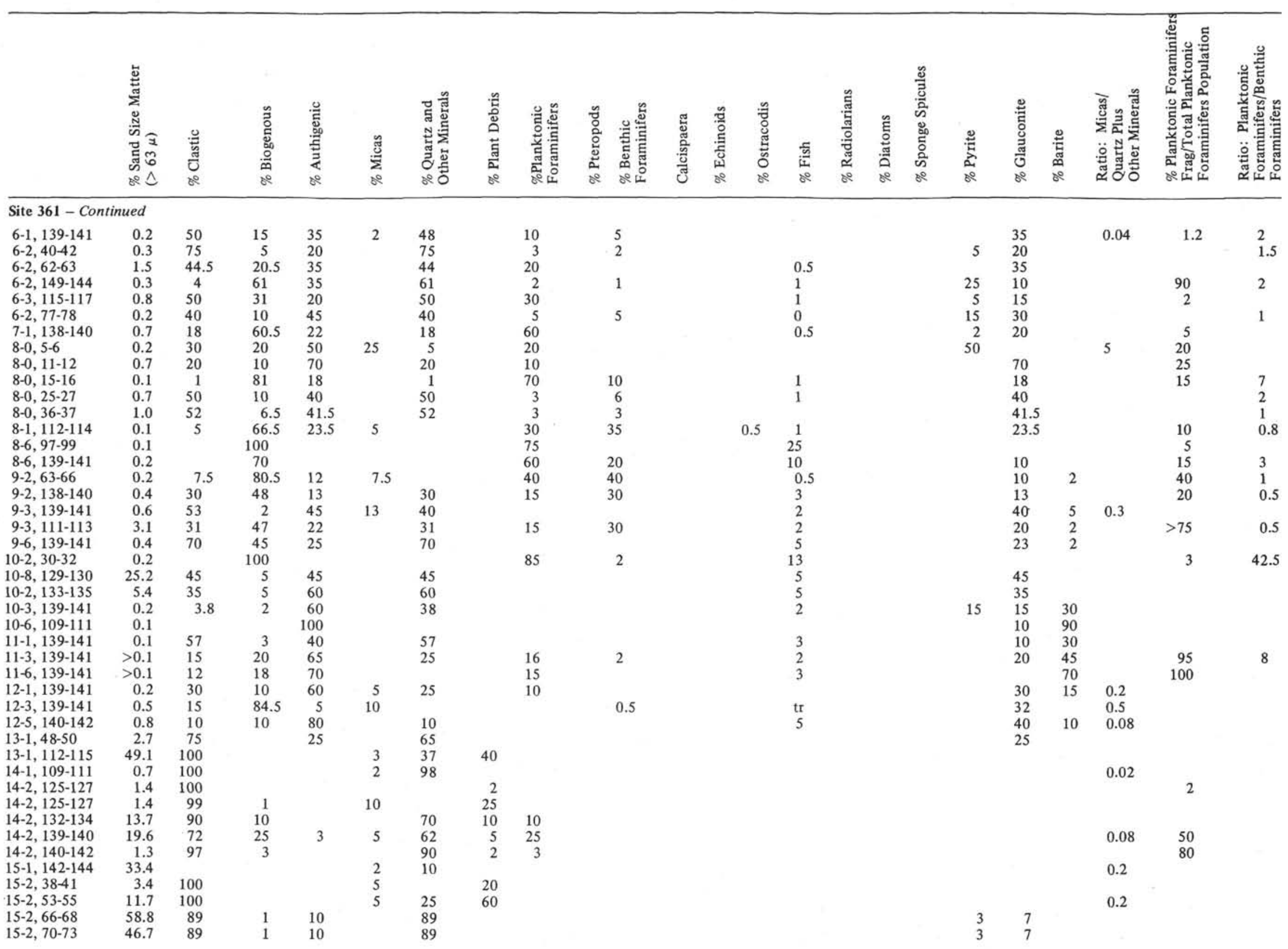




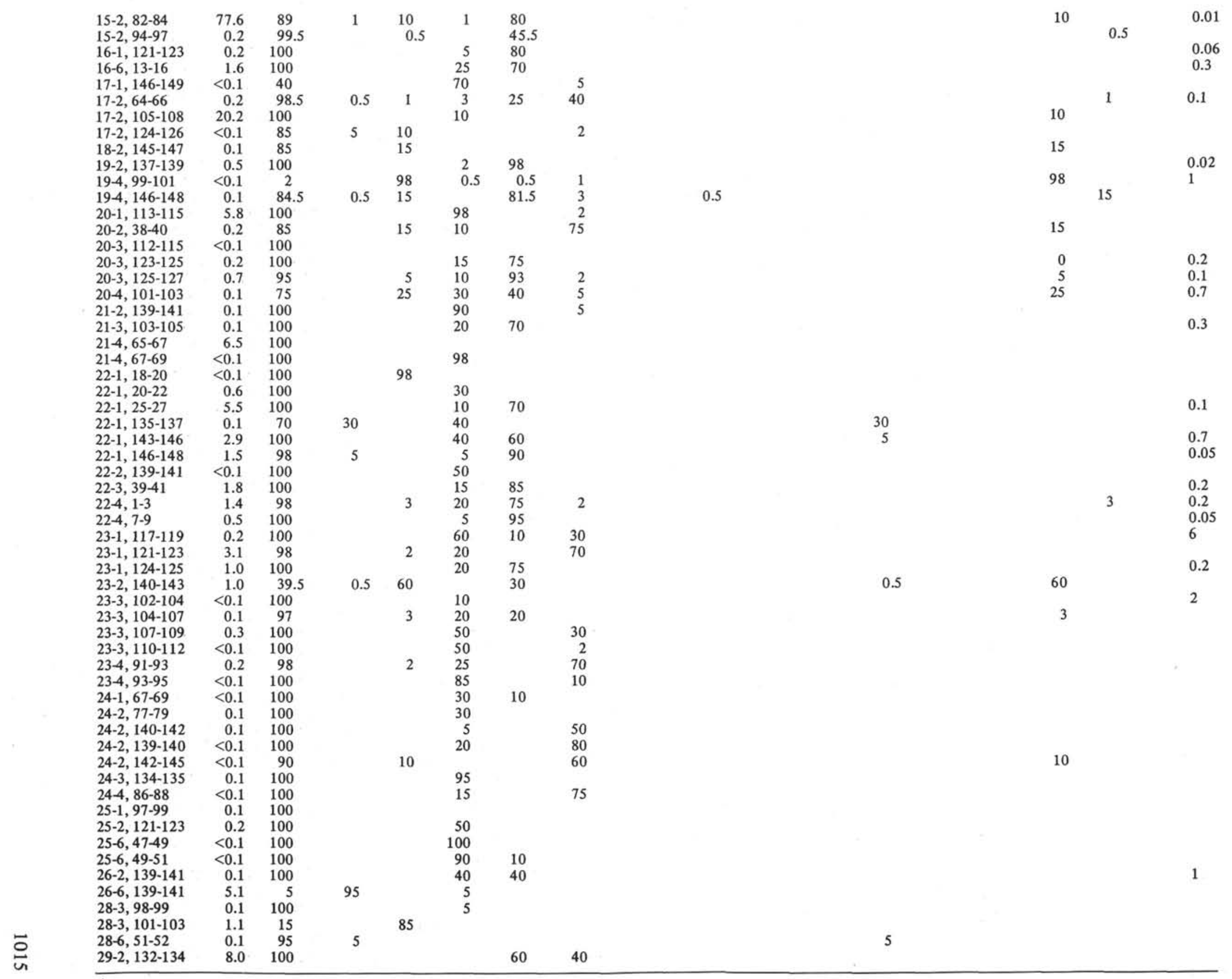




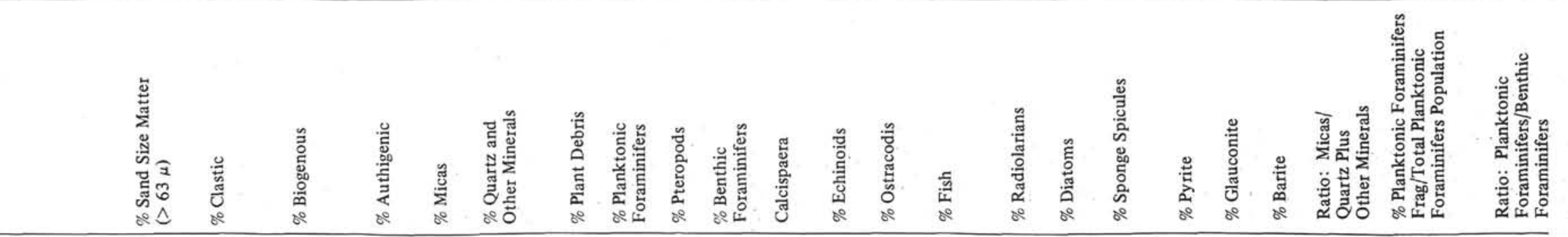

\section{Site 361 - Continued}

29-3, 49-51 $\quad 49.0 \quad 100$ 29-4, 92-94 $\quad 1.0 \quad 100$

$\begin{array}{lll}29-4,96-98 & 5.4 & 100 \\ 29-4,98-99 & 6.4 & 100\end{array}$

$\begin{array}{lll}29-4,98-99 & 6.4 & 100\end{array}$

$\begin{array}{lll}29-4,99-100 & & 100\end{array}$

$\begin{array}{lll}29-5,71-72 & 12.8 & 100\end{array}$

$\begin{array}{lll}29-5,129-131 & 61.0 & 100\end{array}$

30-2, 50-52 $\quad 13.8 \quad 100$

$\begin{array}{lrr}30-2,52-54 & 10.6 & 100\end{array}$

$\begin{array}{rrr}30-2,56-57 & 2.9 & 100 \\ 30-2,59-61 & 19.6 & 100\end{array}$

$\begin{array}{lll}30-2,59-61 & 19.6 & 100 \\ 31-3,64-66 & 40.2 & 100\end{array}$

$31-3,74-76 \quad 11.3 \quad 100$

$32-3,119-121 \quad 44.9 \quad 99$

32-6,139-141 $\quad 1.6 \quad 100$

33-3,75-76 $\quad 6.6 \quad 100$

33-3,76-77 $20.5 \quad 100$

36-1,141-142 $\quad 4.2 \quad 100$

$36-1,145-147 \quad 13.5 \quad 100$

$\begin{array}{lrr}36-1,147-149 & 9.0 & 100\end{array}$

$38-1,90-92 \quad 71.5 \quad 100$

$38-1,90-92 \quad 0.1 \quad 100$

$38-1,94-96 \quad 10.4 \quad 100$

$38-1,96-98 \quad 91.4 \quad 100$

40-3, $107-109 \quad 44.1 \quad 100$

$40-3,120-122 \quad 63.1 \quad 100$

41-2, $18-20 \quad 72.5 \quad 100$

$\begin{array}{rrr}41-2,30-32 & 13.4 & 100 \\ 41-2,36-38 & 11.4 & 98\end{array}$

$\begin{array}{lll}43-3,65-67 & 6.5 & 100 \\ 43-4,22-37 & 0.5 & 100\end{array}$

$\begin{array}{rrr}43-4,22-37 & 0.5 & 100 \\ 43-4,24-26 & 10.2 & 100\end{array}$

$\begin{array}{lrr}43-4,24-26 & 10.2 & 100 \\ 43-4,26.5-27 & 3.6 & 100\end{array}$

$\begin{array}{lll}43-4,26.5-27 & 3.6 & 100\end{array}$

$\begin{array}{lll}43-4,27-28 & 5.6 & 100 \\ 43-4,29-30 & 7.9 & 100\end{array}$

43-4, 29-30 $\quad \begin{array}{rr}7.9 & 100\end{array}$

$\begin{array}{lll}44-3,40-41 & 29.8 & 100 \\ 44-3,42-44 & 22.4 & 100\end{array}$

44-3, 51-52.5 $\quad 14.9 \quad 100$

45-1,136-138 $\quad 18.9 \quad 100$

$\begin{array}{lll}45-2,26-28 & 15.5 & 100\end{array}$

45-2,34-36 $\quad 17.1 \quad 100$

$\begin{array}{lrl}45-3,92-94 & 8.2 & 100\end{array}$

$45-4,31-33$ 


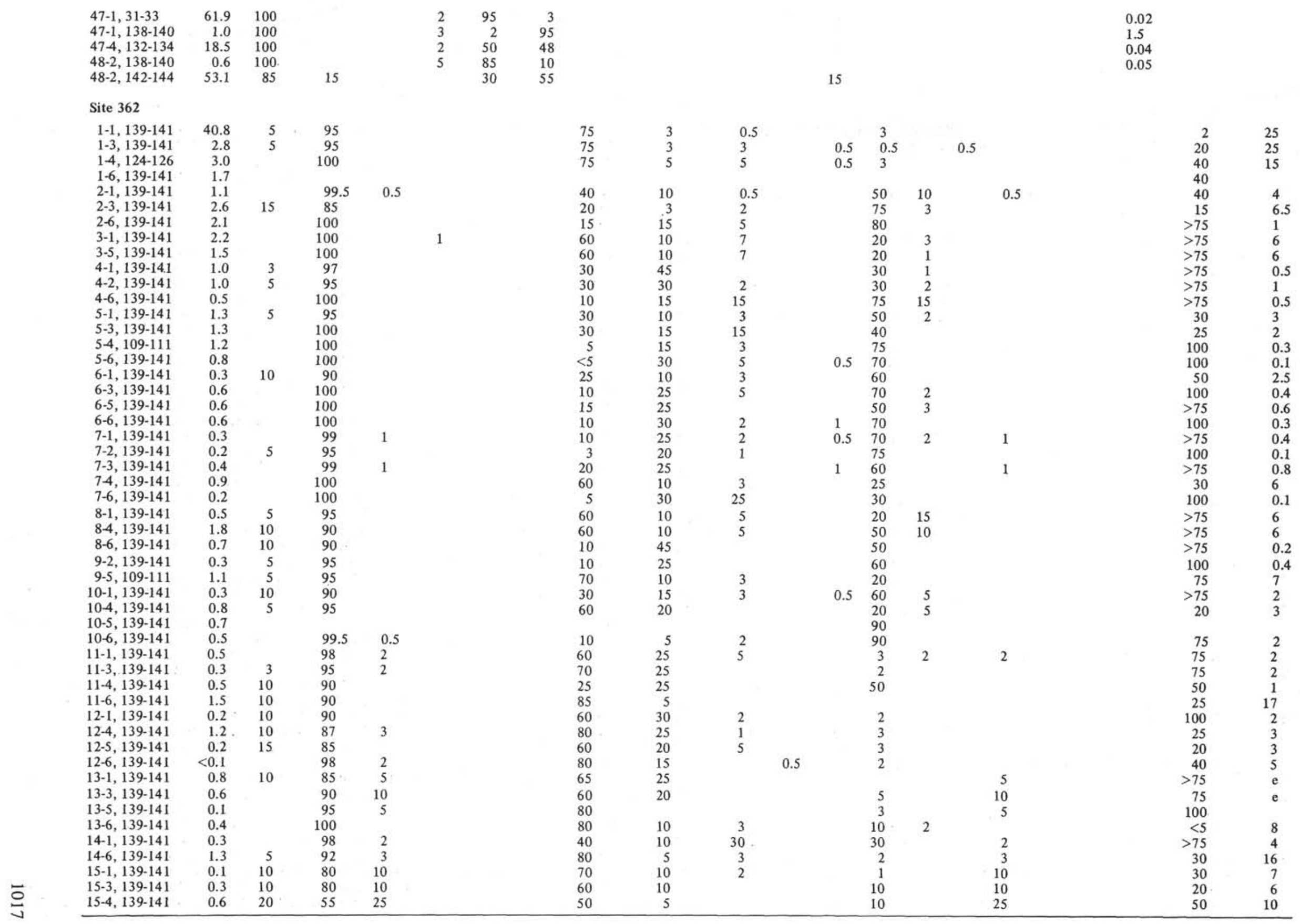




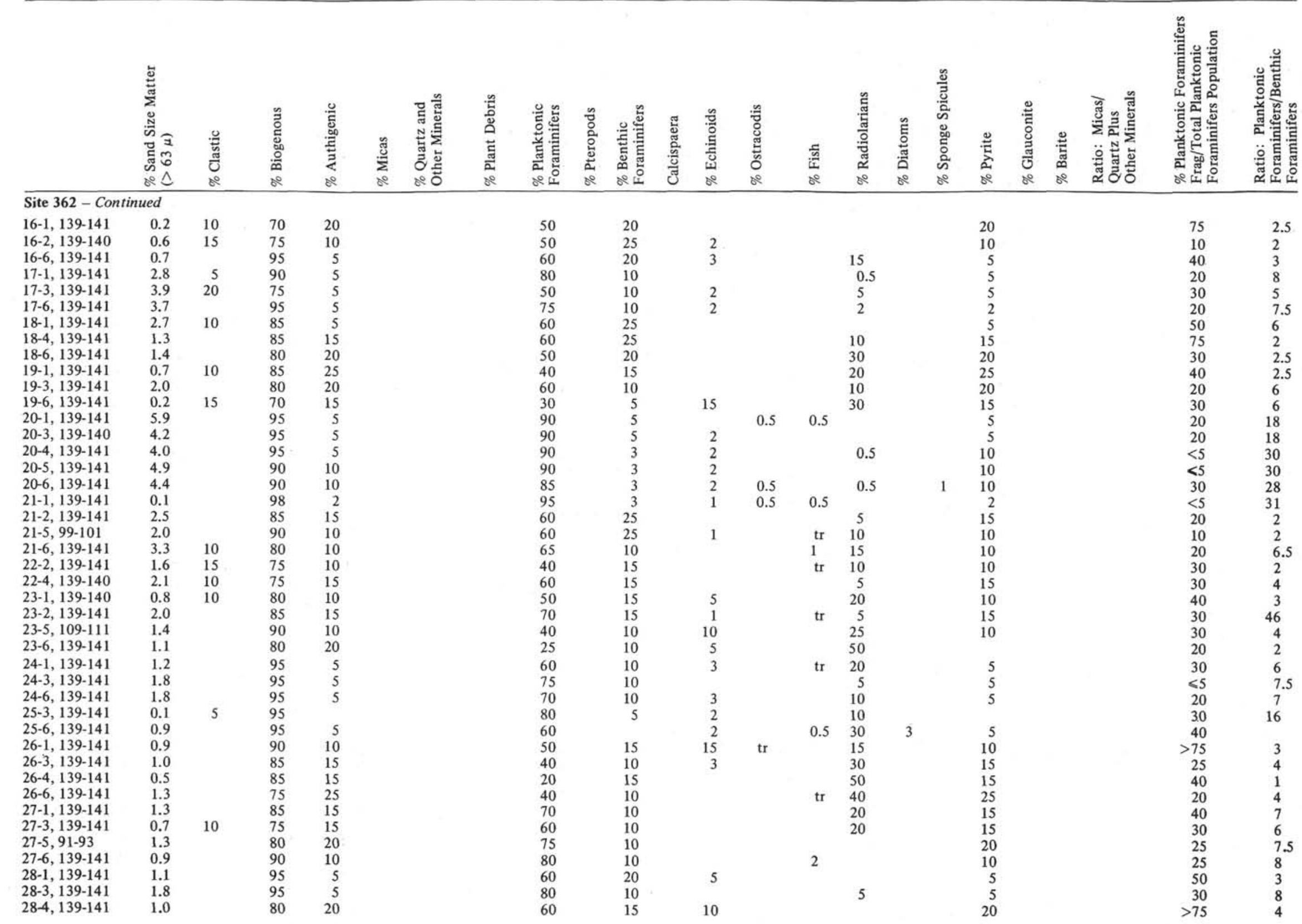




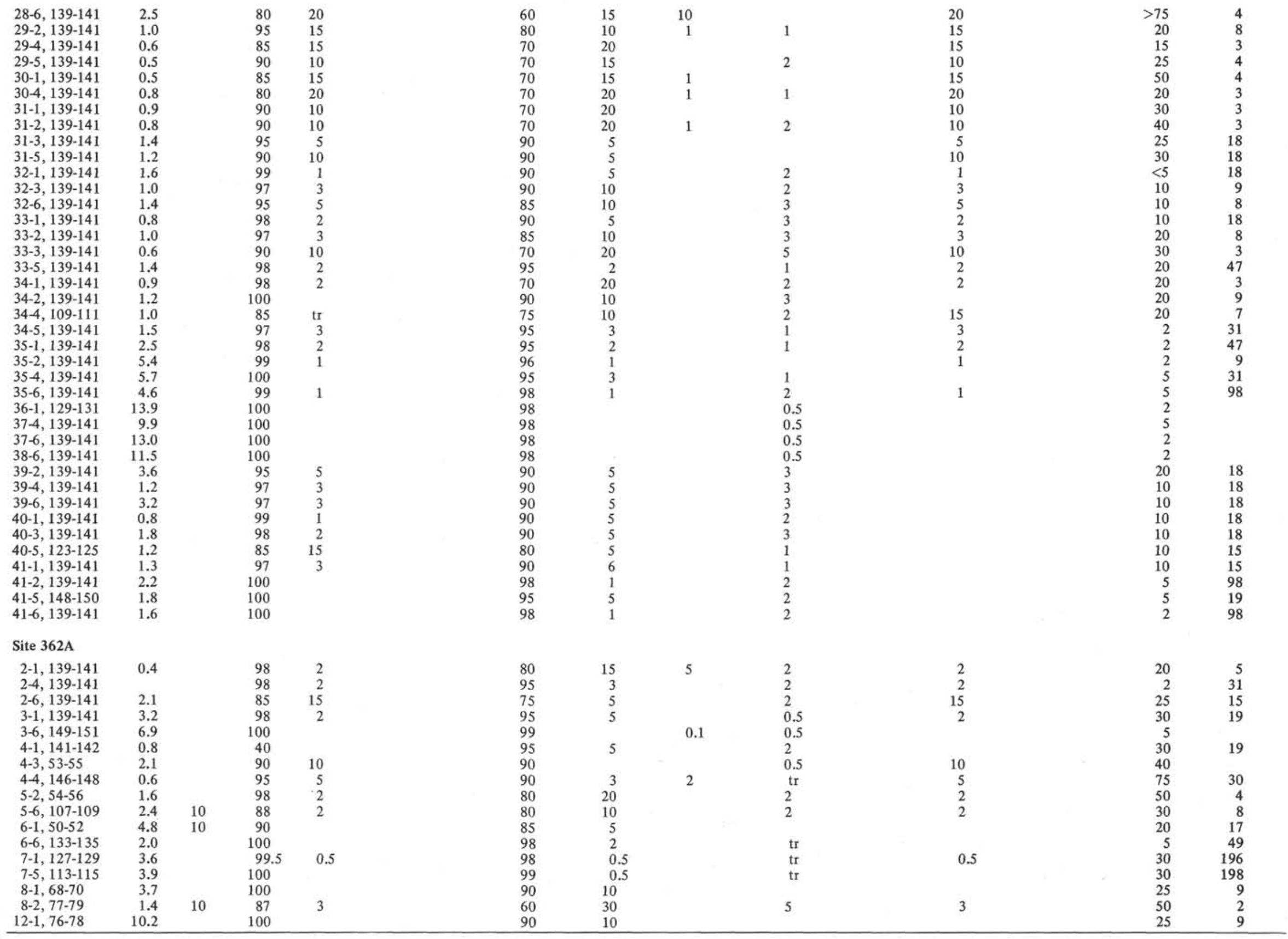




\begin{tabular}{|c|c|c|c|c|c|c|c|c|c|c|c|c|c|c|c|c|c|c|c|c|c|c|c|}
\hline & 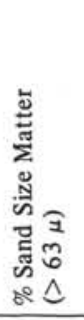 & 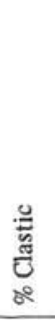 & 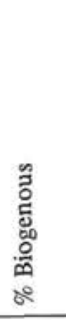 & 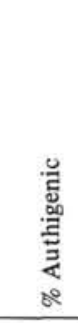 & 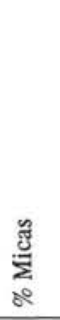 & 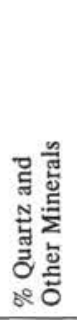 & 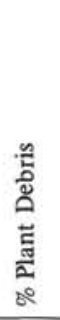 & 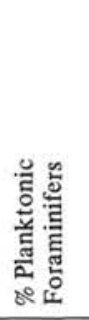 & 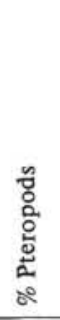 & 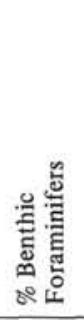 & 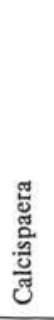 & 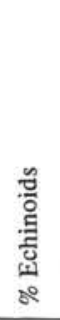 & 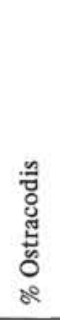 & $\begin{array}{l}\frac{5}{5} \\
\frac{5}{20} \\
0\end{array}$ & 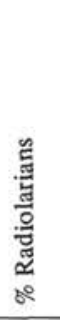 & 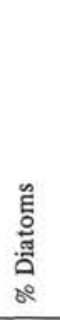 & 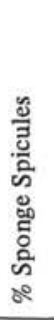 & 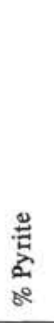 & 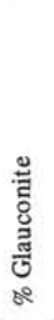 & 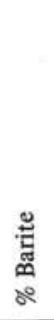 & 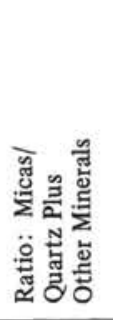 & 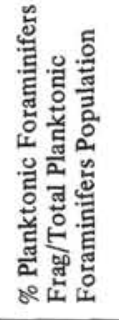 & 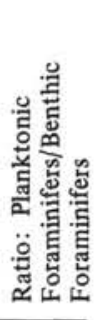 \\
\hline \multicolumn{24}{|l|}{ Site 363} \\
\hline $1-1,139-141$ & 20.2 & & 100 & & & & & $>90$ & & $\leqslant 1$ & & & & & & & & & & & & $\leqslant 10$ & 90 \\
\hline $1-3,139-141$ & 16.2 & & 100 & & & & & $>90$ & & & & & & & & & & & & & & $\leqslant 10$ & \\
\hline $14,109-111$ & 14.8 & & 100 & & & & & $>90$ & & $\leqslant 1$ & & & $<1$ & & & & & & & & & 2 & 90 \\
\hline $1-6,139-141$ & 36.6 & & 100 & & & & & $>90$ & & $\leqslant 1$ & & $<1$ & & & & & & & & & & 2 & 90 \\
\hline $2-1,139-141$ & 10.1 & & 100 & & & & & $>90$ & & $\leqslant 1$ & & $1-5$ & & & & & & & & & & 2 & 90 \\
\hline $2-3,139-141$ & 11.9 & & 100 & & & & & $>90$ & & $\leqslant 1$ & & $\leqslant 1$ & & & & & & & & & & 2 & 90 \\
\hline $2-5,139-141$ & 11.2 & & 100 & & & & & $>90$ & & 5 & & $1-5$ & & & & & & & & & & 2 & 18 \\
\hline $3-1,139-141$ & 8.0 & & 100 & & & & & $>90$ & & 5 & & $\leqslant 1$ & & & & & & & & & & 2 & 18 \\
\hline $3-4,139-141$ & 8.1 & & 100 & & & & & $>90$ & & 5 & & $\leqslant 1$ & & & & & & & & & & 2 & 18 \\
\hline $3-5,139-141$ & 8.2 & & 100 & & & & & $>90$ & & 5 & & $\leqslant 1$ & & & & & & & & & & 2 & 18 \\
\hline $4-3,134-136$ & 10.3 & & 100 & & & & & $\geqslant 90$ & & 2 & & 2 & 1 & & & & & & & & & 10 & 45 \\
\hline $5-2,139-141$ & 5.2 & & 100 & & & & & $>90$ & & 1 & & 1 & $<1$ & & & & & & & & & 5 & 90 \\
\hline $5-3,139-141$ & 7.9 & & 100 & & & & & $>95$ & & 2 & & 1 & & & & & & & & & & 5 & 45 \\
\hline $5-4,110-112$ & 3.6 & & 100 & & & & & $>95$ & & $<1$ & & $<1$ & & 3 & & & & & & & & 5 & 95 \\
\hline $5-5,139-141$ & 5.2 & & 100 & & & & & $>95$ & & 1 & & 1 & & & & & & & & & & 5 & 95 \\
\hline $6-1,139-141$ & 3.6 & & 100 & & & & & $>95$ & & 2 & & 1 & 1 & & & & & & & & & 5 & 47.5 \\
\hline $6-2,139-141$ & 10.7 & & 100 & & & & & $\geqslant 90$ & & 2 & & 1 & 2 & & & & & & & & & 5 & 45 \\
\hline $6-3,139-141$ & 1.7 & & 100 & & & & & $\geqslant 90$ & & 2 & & 1 & 1 & & & & & & & & & 20 & 45 \\
\hline $6-4,139-141$ & 5.5 & & 100 & & & & & $>95$ & & 2 & & 1 & $<1$ & & & & & & & & & 5 & 47.5 \\
\hline $7-1,97-99$ & 0.4 & & 90 & 10 & & & & 75 & & 10 & & 10 & & & & & & 10 & & & & 50 & 7.5 \\
\hline $7, \mathrm{CC}$ & 0.1 & & 100 & & & & & 75 & & 5 & & 25 & & & & & & & & & & 95 & 15 \\
\hline $8-1,99-101$ & 2.4 & & 100 & & & & & 95 & & 2 & & $<1$ & & 2 & & & & & & & & 75 & 47.5 \\
\hline $8-2,139-141$ & 6.8 & & 100 & & & & & $>95$ & & 2 & & $<1$ & $<1$ & & & & & & & & & 30 & 47.5 \\
\hline $9-2,139-141$ & 1.8 & & 100 & & & & & $>90$ & & 5 & & 1 & 2 & & & & & & & & & 20 & 18 \\
\hline $9-3,128-130$ & 3.2 & 2 & 98 & & 2 & & & $>95$ & & 3 & & & 2 & & & & & & & & & 10 & 31.5 \\
\hline $9-4,139-141$ & 2.2 & & 100 & & $\mathrm{tr}$ & & & 90 & & 1 & & $\operatorname{tr}$ & 1 & & & & & & & & & 20 & 90 \\
\hline $10-1,139-141$ & 4.8 & 1 & 99 & & 1 & & & $>95$ & & 1 & & 1 & & & & & & & & & & 20 & 95 \\
\hline $10-2,139-141$ & 4.8 & & 100 & & & & & $>90$ & & 5 & & 1 & 1 & & & & & & & & & 5 & 18 \\
\hline $10-4,139-141$ & 6.6 & & & & & & & $>90$ & & & & & 1 & & & & & & & & & 5 & \\
\hline $10-6,139-141$ & 3.7 & & & & & & & & & & & & & & & & & & & & & 10 & \\
\hline $11-1,139-141$ & 11.9 & & 100 & & $\operatorname{tr}$ & & & $>95$ & & & & 1 & & $\operatorname{tr}$ & & & & & & & & 5 & \\
\hline $11-3,139-141$ & 1.5 & 1 & 99 & & 1 & & & $>98$ & & & & 1 & & & & & & & & & & 10 & \\
\hline $11-6,139-141$ & 8.2 & & 100 & & & & & 98 & & 2 & & & & & & & & & & & & 10 & 49 \\
\hline $12-1,139-141$ & 7.8 & & 100 & & & & & $>90$ & & 5 & & 5 & & & & & & & & & & 10 & 18 \\
\hline $12-2,139-141$ & 8.7 & & 100 & & & & & $>90$ & & 5 & & 5 & & & & & & & & & & 10 & 18 \\
\hline $12-4,139-141$ & 8.9 & & 100 & & & & & $>90$ & & 5 & & 5 & & & & & & & & & & 10 & 18 \\
\hline $12-6,139-141$ & 4.9 & & 100 & & & & & $>90$ & & 5 & & 5 & & & & & & & & & & 10 & 18 \\
\hline $13-2,139-141$ & 5.3 & 1 & 99 & & 1 & & & $>98$ & & & & & & & & & & & & & & 10 & \\
\hline $13-3,128-130$ & 8.4 & 1 & 99 & & 1 & & & 98 & & & & 1 & & & & & & & & & & 2 & \\
\hline $13-5,139-141$ & 7.7 & & 100 & & & & & $>98$ & & & & & & & & & & & & & & 5 & \\
\hline $14-1,139-141$ & 3.8 & & 100 & & & & & $>90$ & & 5 & - & 5 & & & & & & & & & & 10 & 18 \\
\hline $14-2,139-141$ & 3.6 & & 100 & & & & & $>90$ & & 5 & & 5 & & & & & & & & & & 10 & 18 \\
\hline $14-4,135-137$ & 4.1 & & 100 & & & & & $>90$ & & 5 & & 5 & & & & & & & & & & 10 & 18 \\
\hline
\end{tabular}




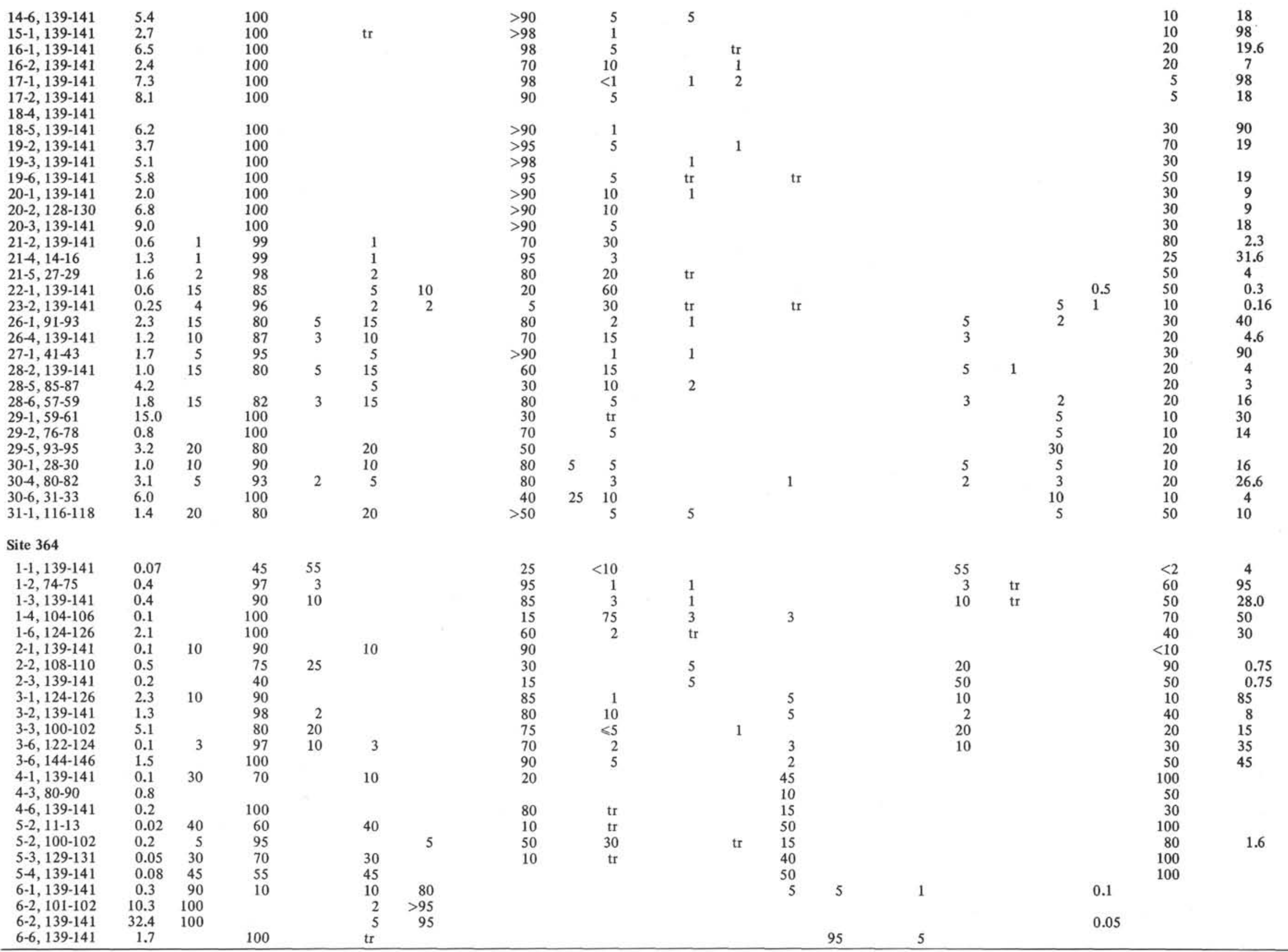

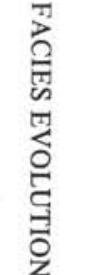




\begin{tabular}{|c|c|c|c|c|c|c|c|c|c|c|c|c|c|c|c|c|c|c|c|c|c|c|c|}
\hline - & 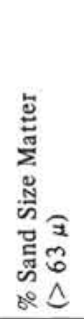 & 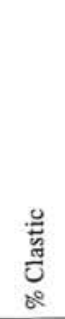 & 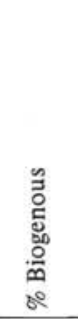 & 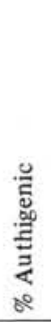 & $\frac{\stackrel{g}{\sharp}}{\sum_{00}^{\circ}}$ & 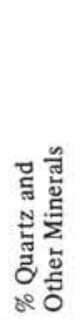 & 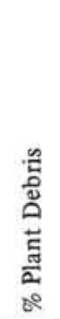 & 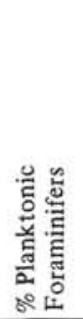 & 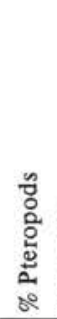 & 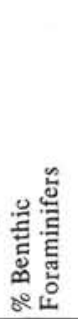 & 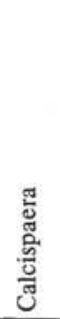 & 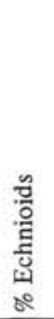 & 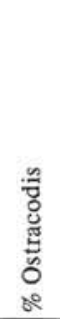 & $\frac{5}{\frac{5}{2}}$ & 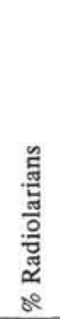 & 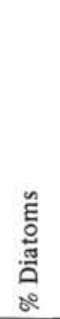 & 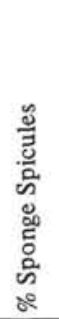 & 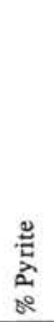 & 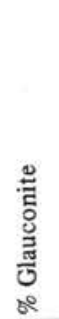 & 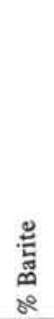 & 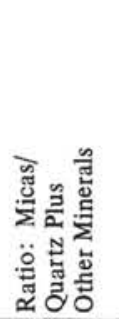 & 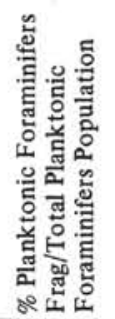 & 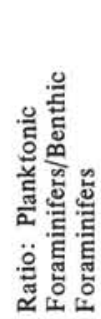 \\
\hline \multicolumn{24}{|c|}{ Site 364 - Continued } \\
\hline $7-1,139-141$ & 1.5 & 30 & 70 & & 25 & 3 & & & & 70 & & & & & & & & & & & & & \\
\hline $8-1,123-125$ & 0.2 & 45 & 55 & & 45 & & & 20 & & 35 & & $\mathrm{tr}$ & & 1 & & & & & & & & 20 & 0.6 \\
\hline $8-1,139-141$ & 0.2 & 45 & 55 & & 35 & & & 5 & & 50 & & & & 2 & & & & & & & & 20 & 0.1 \\
\hline $8-3,139-141$ & 0.4 & 30 & 70 & & 30 & & & 60 & & 2 & & & & 1 & & & & & & & & 40 & 30.0 \\
\hline $8-4,87-89$ & 0.2 & 100 & & & 60 & 30 & & tr & & $\operatorname{tr}$ & & & & tr & & & & & & & 2 & & 1 \\
\hline $8-5,139-141$ & 0.2 & 25 & 75 & & 25 & & & 60 & & 10 & & & & & & & & & & & & 30 & 6 \\
\hline $8-6,90-92$ & 0.1 & 95 & 5 & & $\geqslant 80$ & 1 & & 5 & & & & & & 2 & & & & & & & 80 & 100 & 1 \\
\hline $8-6,140-142$ & 0.5 & 30 & 70 & & 30 & & & 60 & & 15 & & & & & & & & & & & & 40 & 4 \\
\hline $9-1,122-124$ & 6.2 & & 100 & & & & & 100 & & & & & & & & & & & & & & 2 & \\
\hline $9-1,137-138$ & 5.3 & & 100 & & $<1$ & & & 100 & & $\operatorname{tr}$ & & & $\operatorname{tr}$ & & & & & & & & & 15 & \\
\hline $9-4,130-132$ & 0.6 & & 100 & & & & & 90 & & 2 & & $\operatorname{tr}$ & tr & 1 & & & & & & & & 30 & \\
\hline $9-4,132-134$ & 2.0 & & 100 & & 1 & & & $>95$ & & & & & & & & & & & & & & 15 & \\
\hline $10-1,139-141$ & 0.2 & 10 & 90 & & 5 & 5 & & 15 & & 65 & & & & 7 & & & & & & & 1 & 75 & 0.2 \\
\hline $10-2,139-141$ & 0.06 & 20 & 80 & & 20 & & & 5 & & 60 & & & & 5 & & & & & & & & $>90$ & 0.1 \\
\hline $10-3,139-141$ & 4.9 & & 100 & & & & & 99 & & & & & & 1 & & & & & & & & $<5$ & \\
\hline $10-4,102-104$ & 0.3 & 10 & 90 & & 10 & & & 30 & & 20 & & & & 5 & & & & & & & & 40 & 1.5 \\
\hline $10-5,90-92$ & 0.2 & 10 & 90 & & 10 & 3 & & & & & & & & 2 & & & & & & & 3.3 & 5 & 0.06 \\
\hline $10-5,114-116$ & 0.1 & 55 & 45 & & 40 & 15 & & 3 & & 15 & & & & 20 & & & & & & & 2.6 & 20 & 0.2 \\
\hline $10-6,121-123$ & 0.4 & 5 & 95 & & 5 & & & 70 & & 25 & & & 1 & 1 & & & & & & & & 25 & 2.8 \\
\hline $11-1,40-42$ & 0.1 & 15 & 85 & & 15 & 2 & & 5 & & 80 & & 1 & & tr & & & & & & & 7.5 & 10 & 0.06 \\
\hline $11-2,93-95$ & 0.07 & 55 & 45 & & 50 & 3 & & 3 & & 45 & & & & 1 & & & & & & & 16.6 & 10 & 0.06 \\
\hline $11-3,102-104$ & 0.1 & 55 & 45 & & 50 & 3 & & 2 & & 45 & & & & tr & & & & & & & 16.6 & 10 & 0.04 \\
\hline $11-3,134-136$ & 0.1 & 30 & 70 & & 30 & & & 5 & & 60 & & & & 2 & & & & & & & & 10 & 0.08 \\
\hline $11-4,140-143$ & 0.1 & 20 & 80 & & 20 & & & 2 & & 75 & & & & & & & & & & & & 10 & 0.02 \\
\hline $11-5,134-136$ & 0.1 & 30 & 70 & & 30 & 3 & & 2 & & 65 & & & & & & & & & & & 10 & 10 & 0.03 \\
\hline $11-6,40-49$ & 0.1 & 45 & 55 & & 40 & 5 & & 2 & & 50 & & & & $\operatorname{tr}$ & & & & & & & 8 & 10 & 0.04 \\
\hline $12-1,65-67$ & 0.2 & 25 & 75 & & 25 & & & 10 & & 65 & & & & & & & & & & & & 10 & 0.1 \\
\hline $12-1,139-141$ & 0.3 & 40 & 60 & & 25 & 15 & & 5 & & 50 & & & & & & & & & & & 1.6 & 2 & 0.1 \\
\hline $12-2,139-141$ & 0.2 & 40 & 60 & & 30 & 10 & & 5 & & 55 & & & & $\operatorname{tr}$ & & & & & & & 3 & 10 & 0.1 \\
\hline $12-3,139-141$ & 0.2 & 70 & 30 & & 50 & 20 & & & & 30 & & & & & & & & & & & 2.5 & & 0.02 \\
\hline $12-5,38-40$ & 0.2 & 30 & 70 & & 25 & 5 & & 2 & & 70 & & & & & & & & & & & 5 & 10 & \\
\hline $12-6,121-123$ & 0.2 & 25 & 75 & & 20 & 5 & & 5 & & 70 & & & & & & & & & & & 4 & 10 & 0.2 \\
\hline $12-6,139-141$ & 0.2 & 60 & 40 & & 15 & 45 & & 5 & & 25 & & & & & & & & & & & 0.3 & 10 & 0.2 \\
\hline $13-1,61-63$ & 0.3 & 3 & 95 & 1 & & 3 & & 20 & & 50 & & & $\operatorname{tr}$ & & & & & & & & & 10 & 0.4 \\
\hline $13-2,54-56$ & 0.3 & 25 & 75 & & 20 & 3 & & 30 & & 40 & & & $\mathrm{tr}$ & 2 & & & & & & & 6.6 & 10 & 0.75 \\
\hline $13-2,134-136$ & 0.3 & 25 & 75 & & 20 & 3 & & 25 & & 40 & & & & 2 & & & & & & & 6.6 & 10 & 0.6 \\
\hline $14-1,140-142$ & 0.3 & 15 & 85 & & 15 & 2 & & 75 & & 10 & & & & & & & & & & & 7.5 & 5 & 7.5 \\
\hline $14-5,88-90$ & 0.2 & 10 & 90 & & 10 & tr & & 60 & & 25 & & & & tr & & & & & & & & 10 & 2.4 \\
\hline $14-6,41-42$ & 22.8 & 3 & $>95$ & & 3 & & & 10 & & 2 & & & & & & & & & & & & 30 & 5 \\
\hline $14-6,139-141$ & 0.2 & 20 & 80 & & 20 & 1 & & 70 & & 10 & & & & & & & & & & & 20 & 10 & 7 \\
\hline $15-1,139-141$ & 0.2 & 15 & 85 & & 15 & 1 & 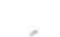 & 50 & & 25 & & & & 2 & & & & & & & 15 & 10 & 2 \\
\hline $15-2,96-98$ & 0.4 & 20 & 80 & & 20 & 2 & & 60 & & 15 & & & & 7 & & & & & & & 10 & 10 & 4 \\
\hline $15-3,134-136$ & 3.5 & 10 & 90 & & 10 & & & 30 & & 10 & & & & & & & & & & & 3 & 20 & 3 \\
\hline $15-3,114-116$ & 0.2 & 20 & 80 & & 15 & 5 & & 40 & & 30 & & & & 10 & & & & & & & & 20 & 1.3 \\
\hline
\end{tabular}




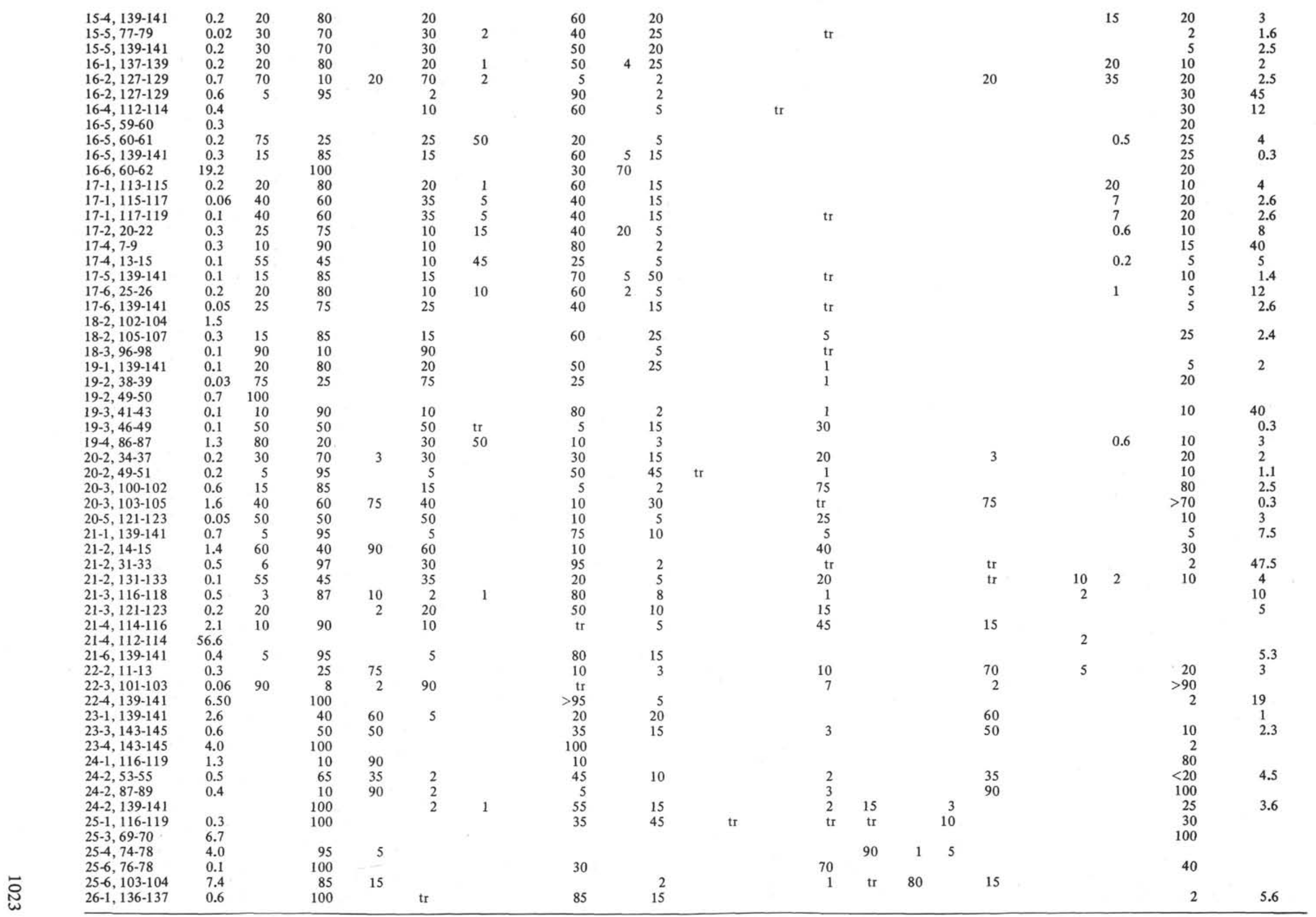

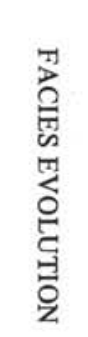


Site 364 - Continued

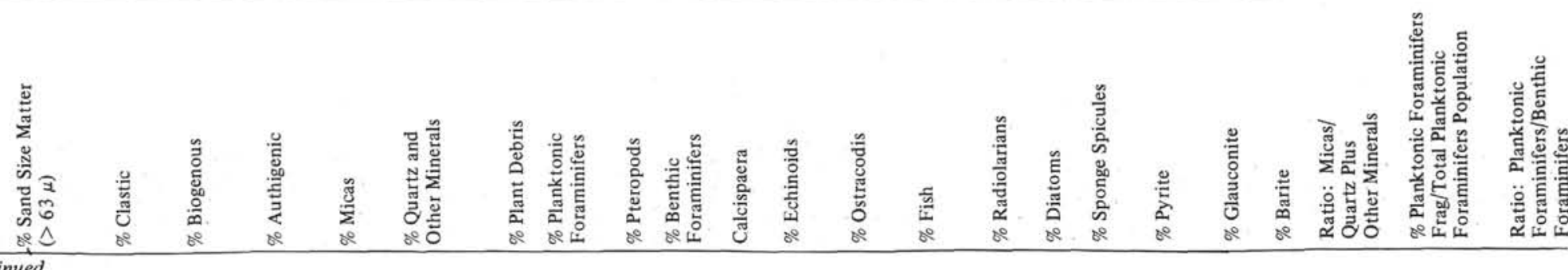

26-2, 98-99 $26-3,56-58$
$26-4,77-78$ $26-5,63-65$
$26-6,53-54$ 26-6, 53-54 26-6, 140-142 27-1, 138-139 27-2, 139-141 27-2, 166-168 27-3, 27-28 27-3, 36-38 $27-4,67-68$ 27-5, $94-96$ 28-1, $51-52$ 28-2, 31-33 $28-3,74-76$
$29-2,0-2$

29-2, 0-2

29-1, $226-12$

29-3, 45-48

29-3, 100-101

$29-4,24-26$

$30-1,141-143$

30-2, 109-111

$30-3,25-27$

$31-1,24-26$

$31-2,123-125$

$31-3,119-121$

$32-1,39-41$

32- $32,143-14$

32-3, 32-34

$33-1,92-94$

$33-3,121-122$

33-5, 36-37

$33-4,114-116$

$33-5,47-50$

34-1, 112-115

$34-1,141-143$
$34-3,28-30$

34-2, 196-127

$34-4,51-53$

$35-2,74-76$

$35-3,74-7$

$37-1,7-9$

$37-3,89-90$

$38-4,137-139$

$\begin{array}{rrrrr}1.5 & & 100 & 2 & 80 \\ 0.1 & 30 & 50 & 30 & 50 \\ 2.9 & & 100 & 1 & 90 \\ 4.5 & & 100 & & 15 \\ 4.8 & & 100 & & 70 \\ 2.8 & & 100 & & \\ 3.7 & & 100 & 5 & >95 \\ & 5 & 95 & & \end{array}$

1

39-3, 60-69

23.0
3.6
17.4

100

100
100

100

100
100

$3.4 \quad 100$

10.9

0.8

100

$\approx 100$

4.6
3.6
8.8
4.9

8.8
4.9
1.8
5.0

100
80

$\begin{array}{r}98 \\ 95 \\ >95 \\ \hline 98\end{array}$

6.6

7.3

15.7
6.5

4.5
12.9

1.6
0.3
0.3

0.3
0.3
3.8
5.9

5.9
5.6

17.5

11.5

14.5
9.5

1005

$18.1 \quad 2$

4.6
23.5

23.5
8.9

8.9
18.4

11.5

11.5
6.8

6.8
6.2

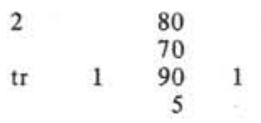

$>95$

$>90$ 